\title{
LA-UR-15-21896
}

Approved for public release; distribution is unlimited.

Title:

Author(s):

Intended for:

Issued:
Fiscal Year 2015 Site Sustainability Plan

Witt, Monica Rene

Report

2015-03-16 
Disclaimer:

Los Alamos National Laboratory, an affirmative action/equal opportunity employer,is operated by the Los Alamos National Security, LLC for the National NuclearSecurity Administration of the U.S. Department of Energy under contract DE-AC52-06NA25396. By approving this article, the publisher recognizes that the U.S. Government retains nonexclusive, royalty-free license to publish or reproduce the published form of this contribution, or to allow others to do so, for U.S. Government purposes. Los Alamos National Laboratory requests that the publisher identify this article as work performed under the auspices of the U.S. Departmentof Energy. Los Alamos National Laboratory strongly supports academic freedom and a researcher's right to publish; as an institution, however, the Laboratory does not endorse the viewpoint of a publication or guarantee its technical correctness. 


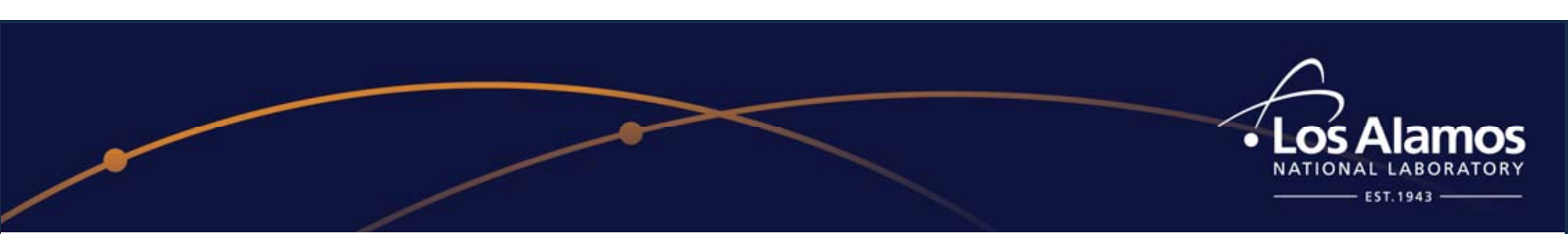

\section{FISCAL YEAR 2015 SITE SUSTAINBILITY PLAN}

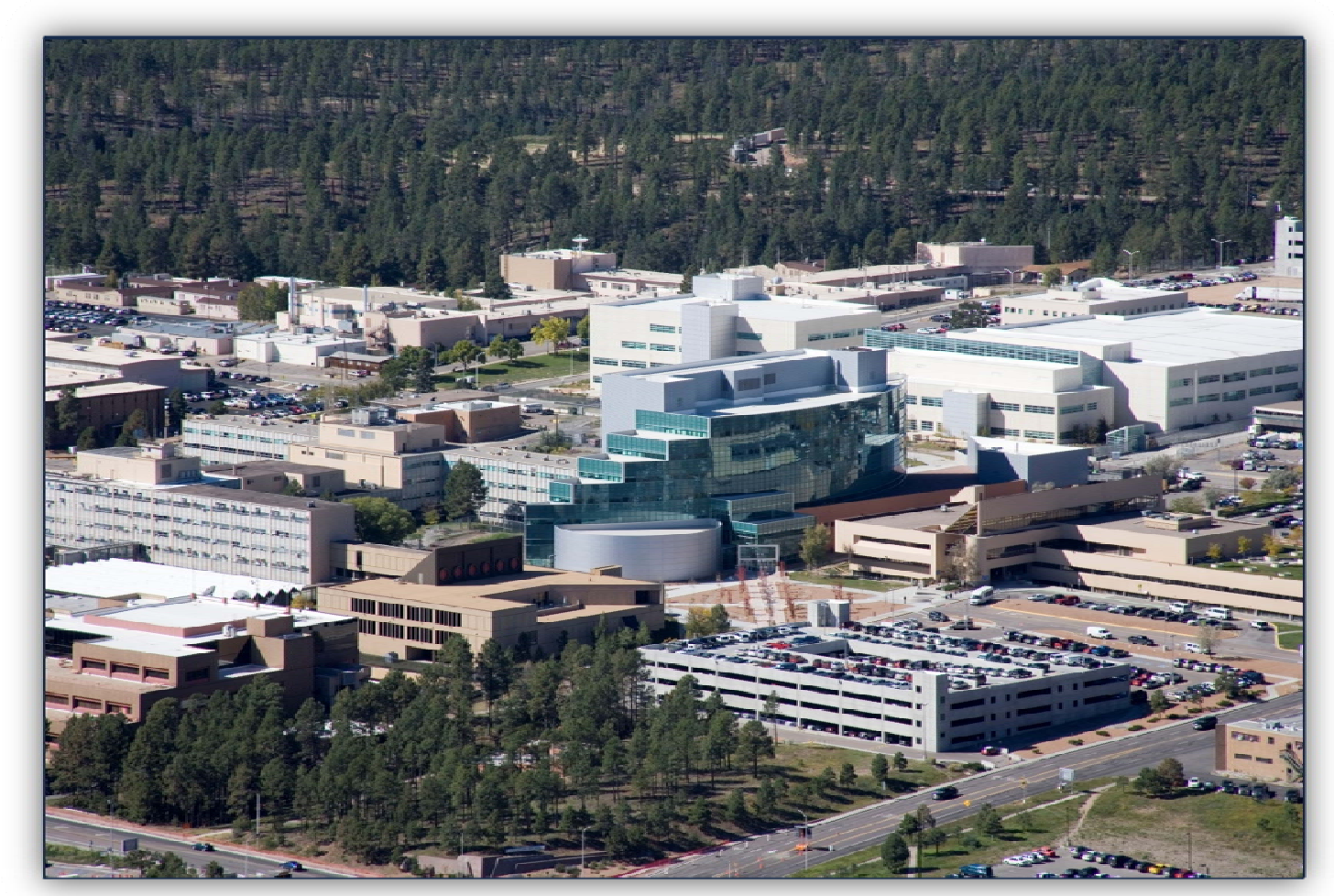

Approved By:

Chural D. Cabbil Date: $12-11-2014$ Cheryl D. Cabbil Associate Director for Nuclear and High Hazard Operations 
This page is intentionally left blank. 


\section{TABLE OF CONTENTS}

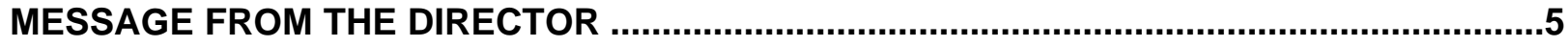

1.0 EXECUTIVE SUMMARY ...................................................................................

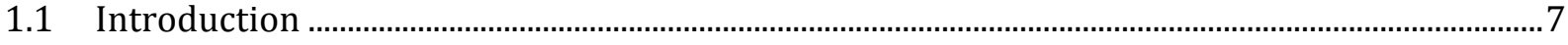

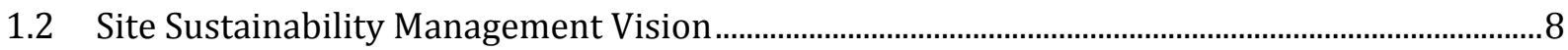

1.3 Major Site Sustainability Planning Assumptions: Issues \& Funding Strategies ..........................

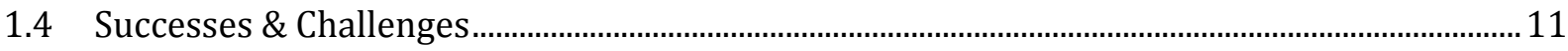

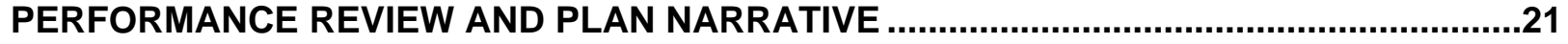

GOAL 1: Greenhouse Gas Reduction and Comprehensive Greenhouse Gas Inventory....................... 21

GOAL 2: Buildings, ESPC Initiative Schedule, and Regional \& Local Planning...................................... 24

GOAL 3: Fleet Management .............................................................................................................. 37

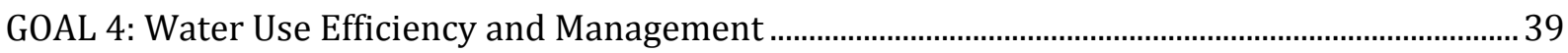

GOAL 5: Pollution Prevention............................................................................................................... 43

GOAL 6: Sustainable Acquisition .......................................................................................................... 47

GOAL 7: Electronic Stewardship and Data Centers ............................................................................... 48

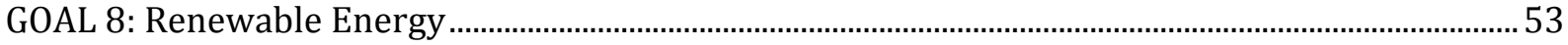

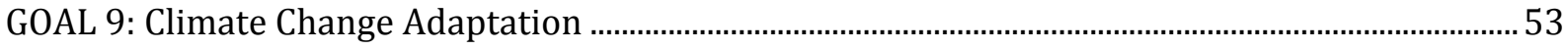

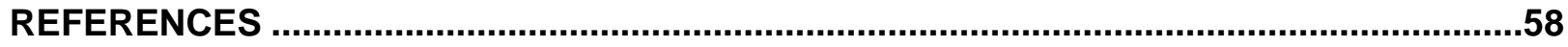

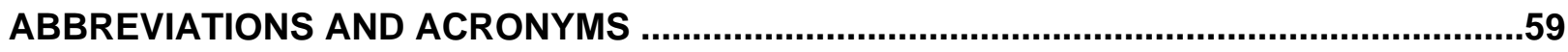

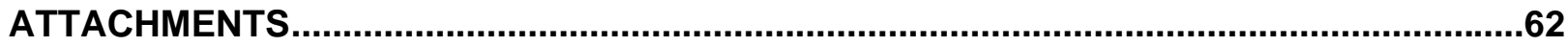


This page is intentionally left blank. 


\section{MESSAGE FROM THE DIRECTOR}

Last year I again challenged Laboratory employees to reduce our environmental impact. I am pleased to report that through the actions taken in our directorates' Environmental Action Plans, and the efforts of many dedicated individuals, my challenge was successfully met, and we are operating a more efficient Laboratory today than we were yesterday. Our site experienced a reduction in energy (11\% over last year), water ( $30 \%$ over last two years), and overall energy intensity (more than $16 \%$ over last 10 years), all while growing high energy missions like computing.

The achievements of today's Laboratory must be extended and new sustainable initiatives implemented

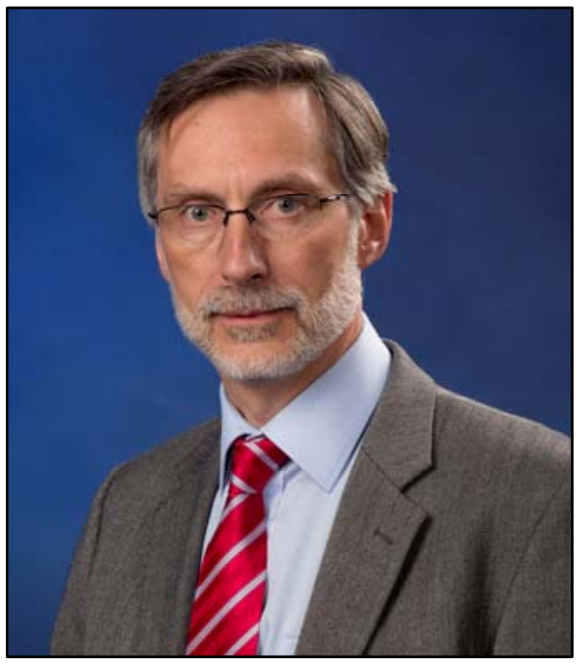
for the Lab of the future. It is only through the cumulative effect of consistent efforts taken over a number of years that we will accomplish our mission in a sustainable manner.

Together we can maintain this momentum by taking further action on the sustainability built into our Strategic Plan's four goals. We can

1. Accomplish our core stockpile stewardship mission and global security activities in a sustainable way;

2. Continue breakthrough science that furthers national energy goals;

3. Make the Laboratory of the best places in the world to work by increasing energy awareness, promoting sustainable behavior, and continuing site planning work that keeps our surroundings safe and clean; and,

4. Conduct our operations in a manner that applies sustainable solutions to infrastructure, purchasing, transportation, and waste decisions.

Sustainability must be a part of the way we do business. It is an investment in our future, results in cost savings, and complements our Long-Term Strategy for Environmental Stewardship and Sustainability. Our "Bold Future" is dependent upon each of us consistently incorporating environmentally conscientious decisions in all we do.

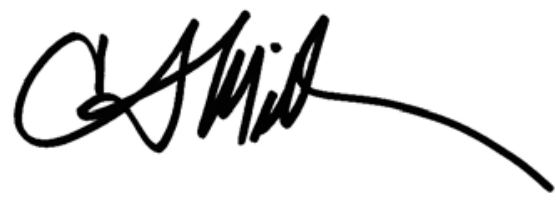

Charles F. McMillan

Director

Los Alamos National Laboratory 
This page is intentionally left blank. 


\subsection{EXECUTIVE SUMMARY}

\subsection{INTRODUCTION}

Los Alamos National Laboratory is taking action to operate as a living laboratory for sustainable solutions in buildings, climate, energy, purchasing, transportation, waste, and water. Executive Orders (EO) 13423, Strengthening Federal Environmental, Energy, and Transportation Management, and 13514, Federal Leadership in Environmental, Energy, and Economic Performance, and The United States (U.S.) Department of Energy (DOE) Strategic Sustainability Performance Plan (SSPP) detail sustainability goals for all sites, including:

- Planning, executing, evaluating, and continually improving DOE operations to maximize sustainable use of energy and natural resources

- Developing cost-effective energy efficiency and renewable energy (RE) projects

- Improving the performance of existing facilities

- Using low-greenhouse gas (GHG)-emitting energy sources to replace existing grid energy

- Preventing pollution and reducing or eliminating the generation of waste

LANL prepared the fiscal year (FY) 2015 Site Sustainability Plan (SSP) to describe progress towards the goals established in the SSPP. In addition, per the requirements of DOE Order 436.1, Departmental Sustainability, Los Alamos National Laboratory (LANL) uses its International Organization for Standardization (ISO) 14001:2004 certified Environmental Management System (EMS) to establish objectives to improve compliance, reduce environmental impacts, increase operational capacity, and meet long-term sustainability goals. The goals of the 2015 SSP are fully integrated into LANL's institutional environmental objectives under the EMS and its Long-Term Strategy for Environmental Stewardship \& Sustainability (LTSESS).

LANL's SSP is managed through the Principal Associate Director for Operations and Business. The Laboratory also issued a program description document setting up the Site Sustainability Program, which was established in order to meet the sustainability goals prescribed by the DOE SSPP. The Site Sustainability Program reports to the Environmental Senior Management Steering Committee as part of the quarterly EMS management review process.

The challenges presented by the sustainability goals established in DOE Order 436.1 require innovative solutions that draw upon the many organizations, resources, and talents at the Laboratory. This SSP follows DOE's Guidance for FY 2015 DOE Site Sustainability Plans and the NNSA Supplemental Guidance. The FY 2015 SSP builds on the FY 2014 accomplishments and outlines FY 2015 actions that enable LANL to continue progress toward DOE's sustainability reporting requirements and goals.

LANL has invested in a number of projects, including the Sanitary Effluent Reclamation Facility (SERF) operations, High Performance Sustainable Building (HPSB) implementation, heating, ventilation, and air conditioning (HVAC) re-commissioning, building automation system (BAS) upgrades for night set-back capability, and footprint reduction efforts to contribute toward energy, water, and GHG reduction goals.

LANL reduced energy intensity (BTU/sq. ft.) by over 16\% compared to the 2003 baseline year and has reduced water consumption by $20 \%$ compared to FY 2013. LANL will continue to invest in facility upgrades including HVAC recommissioning and BAS upgrades to reduce energy consumption. 
In FY 2015, through investments in building automation systems, lighting, and other sustainability projects, LANL plans to achieve the following sustainability goals:

- Reduce energy intensity by 3\% compared to FY 2014 from the 2003 baseline $(18.5 \%$ by the end of FY 2015) and

- Maintain water use at or below FY 2014 levels

In addition, LANL is relying on broad employee engagement in site sustainability efforts through LANL's EMS to reduce energy, water, and waste generation through its programs.

\subsection{SITE SUSTAINABILITY MANAGEMENT VISION}

The intent of the Site Sustainability Program is to incorporate energy and water conservation into everyday business practices. The program manages, implements, and tracks progress toward meeting DOE SSPP's goals. The program is responsible for reporting progress toward Site Sustainability Plan milestone implementation to the Senior Environmental Steering Committee and Los Alamos Field Office through metrics in the LANL Dashboard system (Figure 1), which is part of the Laboratory's Contractor Assurance System.

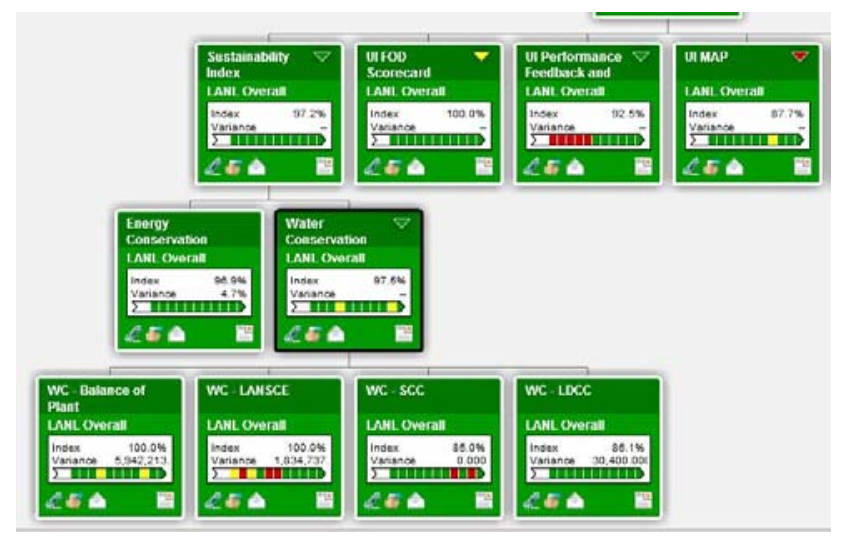

Figure 1. LANL Sustainability Goals in Senior Management Metrics Dashboard

The Site Sustainability Program provided its Consolidated Energy Data Report (CEDR), published with the annual Site Sustainability Plan, to the National Nuclear Security Administration (NNSA) to be included in the annual NNSA Composite Sustainability Plan. The program receives funding to prioritize and execute projects to assist in meeting the Site Sustainability Plan milestones. In addition, the Site Sustainability Program has established a longer-term sustainability strategy based on compliance with the requirements and goals established in the DOE SSPP and DOE 0 436.1, Departmental Sustainability.

LANL's LTSESS articulates the Laboratory's vision for sustainability as an integral part of our mission to meet the nation's scientific challenges. Implementation of that vision on a tactical level is managed through a number of institutional plans. The annual Site Sustainability Plan is one of the Laboratory's key plans to focus on three primary objectives: make targeted investments that improve our efficiency and resource utilization, transparently track our progress through metrics, and engage employees and programs at all levels in the organization through its established ISO 14001:2004-certified Environmental Management System (EMS). The Site Sustainability Program works to integrate its sustainability strategy and objectives with other related Laboratory programs and plans including the LTSESS. 
LANL's EMS established goals and objectives for FY 2015 address LANL's key environmental improvement priorities and significant environmental aspects. The EMS program engages employees and organizations across the Laboratory to ensure that sustainability is part of the program execution. Energy and water use, GHG, pollution prevention, sustainable acquisition, and storm water management are considered significant environmental aspects for LANL and organizations are encouraged to identify actions to mitigate their impact and work toward achieving the goals in the Site Sustainability Plan.

\subsection{MAJOR SITE SUSTAINABILITY PLANNING ASSUMPTIONS: ISSUES \& FUNDING STRATEGIES}

In FY 2015, the Laboratory will invest $\$ 3.3 \mathrm{M}$ in the Site Sustainability Program, provided by the Director through indirect funding. Additionally the Laboratory invests $\$ 3.2 \mathrm{M}$ per year of indirect funding in the operation of SERF to achieve its water reductions.

The Laboratory is also investing in facility renovation and rehabilitation to improve material condition in the facilities and consolidate operations. This effort is being conducted in conjunction with the footprint reduction efforts at the Laboratory to right-size available institutional space. Many of the facility renovation, rehabilitation, or footprint reduction efforts have a corresponding benefit to reduce energy and water consumption. LANL continues to work on improving long-range space planning to take credit for the impacts on the sustainability goals.

Staffing levels for the program include four full-time equivalent (FTEs) employees for executing measurement and verification, energy and water conservation project implementation, energy and water audits, program reporting and communication, and program management. In addition, a number of additional staff from Engineering Services, Construction Management, and Utilities and Institutional Facilities (UI) Operations and Maintenance supports project execution for the Site Sustainability Program.

LANL completes pollution prevention (P2) and waste minimization efforts in compliance with DOE O 436.1, DOE 0 435.1, DOE 0 458.1, and the New Mexico Environment Department (NMED) Hazardous Waste Facility Permit. LANL provides funding for pollution prevention and waste minimization projects, for core subject matter expert (SME) institutional support staff, and for pollution prevention, waste minimization, EMS, and sustainable acquisition compliance reporting.

In FY 2014, the Pollution Prevention program, which directly funds generators to execute pollution prevention and waste minimization projects, totaled approximately \$1.4M. In FY 2015, LANL will fund the Pollution Prevention program from the Infrastructure Support Program and provide approximately $\$ 1.2 \mathrm{M}$ for pollution prevention and waste minimization projects, and core SME support and annual compliance reporting will be funded at $\$ 240,000$.

The Laboratory's Site Sustainability Program developed a long-range Sustainability Funding Strategy. If funded as requested, the Program has the opportunity to meet key SSPP goals within the next five years. For example, if the FY 2015 energy intensity goal project work is funded at a level of $\$ 2-3 \mathrm{M} /$ year for the next four years, a total reduction of 30\% is achievable in the FY 2018-2020 range. More importantly, if the Program is funded as requested, the breakeven return on investment will be achieved after approximately seven years. If the Program is not funded, LANL most likely could maintain the $16 \%$ energy intensity reduction compared to FY 2003, but is unlikely to progress further.

In order to make progress toward the sustainability goals, LANL will pursue a combination of additional investments in renewable energy, High Performance Sustainable Building projects, and facility and operational improvements for energy efficiency. LANL has developed a Return on 
Investment (ROI) funding strategy to work toward achieving the SSPP goals. This strategy includes investing in recommissioning, facility improvements, building automation systems, publicity and outreach, lighting retrofits, and implementing energy and water conservation measures. The FY 2015 projects were selected to target facilities with a high energy intensity or consumption. LANL uses a database to track all potential conservation measures. This database compares approximately 100 conservation measures based on a simple return on investment calculation. In addition, LANL uses this database to track savings associated with completed conservation measures. LANL's Site Sustainability Program is requests additional funding from the Institutional Support Program each year to make significant progress on the SSPP goals and has identified unfunded high priority projects (Table 1). LANL has identified this long-range Sustainability Funding Strategy that could enable the Laboratory to close the gap on energy intensity performance within the next five years and continue to invest in order to meet the greenhouse gas reduction targets. The funding strategy includes projects that will require a diverse set of funding mechanisms including grants, indirect, and Energy Savings Performance Contracts. The Consolidated Energy Data Report includes a list of ranked potential sustainability projects (see Attachment 1).

Table 1. Site Business Case for Key Unfunded Sustainability Projects

\begin{tabular}{|c|c|c|c|c|c|c|c|c|}
\hline $\begin{array}{l}\text { Project } \\
\text { No. }\end{array}$ & $\begin{array}{l}\text { Conservation } \\
\text { Measure Name } \\
\text { or Description }\end{array}$ & $\begin{array}{c}\text { Starting } \\
\text { Year }\end{array}$ & $\begin{array}{c}\text { Est. Imp. } \\
\text { Cost } \\
\text { (\$) }\end{array}$ & $\begin{array}{c}\text { Est. } \\
\text { Annual } \\
\text { Energy } \\
\text { Savings } \\
\text { (BTU^6) }\end{array}$ & $\begin{array}{c}\text { Est. } \\
\text { Annual } \\
\text { Energy } \\
\text { Cost } \\
\text { Savings } \\
(\$ / Y r)\end{array}$ & $\begin{array}{c}\text { Payback } \\
\text { Year } \\
\text { Time (Yr) }\end{array}$ & SIR & Status \\
\hline $\begin{array}{l}\text { NNSA- } \\
0101-0007\end{array}$ & $\begin{array}{l}\text { Cogen, TA3 } \\
\text { steam system } \\
\text { reconfigure }\end{array}$ & 2015 & $\$ 125 M$ & 50,000 & $\begin{array}{l}\$ 250,000 \\
\text { (see note } \\
\text { below) }\end{array}$ & 10 & 1.7 & Identified \\
\hline none & $\begin{array}{l}5 \mathrm{MW} \\
\text { Photovoltaic Plant }\end{array}$ & none & $\$ 25 \mathrm{M}$ & 37,500 & $\$ 880,000$ & 28 & 0.72 & Identified \\
\hline none & $\begin{array}{l}\text { Server } \\
\text { Consolidation }\end{array}$ & none & $\$ 3 M$ & 6100 & $\$ 144,000$ & 21 & 0.73 & Identified \\
\hline none & $\begin{array}{l}\text { Compressed Air } \\
\text { Systems } \\
\text { Optimization }\end{array}$ & none & $\$ 173,112$ & 1410 & $\$ 33,072$ & 5 & 2.89 & Identified \\
\hline none & VFDs on Motors & none & $\$ 178,000$ & 760 & $\$ 17,800$ & 10 & 1.52 & Identified \\
\hline none & $\begin{array}{l}\text { Lighting \& } \\
\text { Controls Retrofits }\end{array}$ & none & $\$ 7.2 \mathrm{M}$ & 17,448 & $\$ 409,000$ & 18 & 0.86 & Identified \\
\hline none & $\begin{array}{l}\text { Energy Star } \\
\text { Equipment }\end{array}$ & none & $\$ 393,700$ & 780 & $\$ 18,300$ & 22 & 0.70 & Identified \\
\hline Total & & & $\$ 161 \mathrm{M}$ & 113,998 & & & & \\
\hline
\end{tabular}


Note on the proposed Cogeneration Project at TA-3: The project is presented here as a self-funding ESPC project; it will produce electricity at the price LANL currently pays, and with a portion of this income, a bond obtained by the ESCO to finance the project will be paid off over 20 years. A maintenance budget is included in the financial model to keep the plant in usable condition for 30 years. The project is financially attractive, saving an average $\$ 12.6$ million/year, primarily because, after the bond is paid off, the price of its electricity drops. Additional savings are realized due repairs on the steam distribution system that save $\sim 50,000$ million BTU/yr and because the new plant has reduced operating costs versus the existing plant.

\subsection{SUCCESSES \& CHALLENGES}

LANL's sustainability successes include a leadership structure that supports and encourages efficient business best practices. Investments in local, economically viable, renewable energy systems, facility improvements, footprint reduction, and sound metrics form a firm foundation to advance sustainability. In addition, just as critical to success, is the partnership between the science to advance sustainability and the operations responsible for implementing sustainability. The synergy between the scientific and operations staff provides a unique capability that can cultivate a new environment to bridge the gap between mission growth and resource use beyond existing capacity.

NNSA awarded 15 Sustainability Awards for innovation and excellence to its national laboratories and sites, and LANL was among the winners, with honorees in both the Best in Class and Environmental Stewardship categories. In the "Best In Class" category, Los Alamos was honored for Green Buildings: High Performance Sustainable Building Integrated Commissioning Team. This award recognized the project for implementing comprehensive green building principles and making progress toward meeting the Guiding Principles for High Performance Sustainable Buildings. The project involved recommissioning buildings to optimize performance of existing systems such as heating and electrical controls. For Environmental Stewardship Awards, the Laboratory also earned the following:

- Change Agent: Jean Dewart: This award category recognizes an individual who takes the initiative to foster behavior change.

- Service/Sustainability Champion: Dr. John S. Isaacson - A Sustainability Champion. The exceptional/sustainability champion demonstrates a history of exemplary performance in leading implementation of sustainable practices.

- Greenhouse Gas Scope 1 and 2: Eliminating Sulfur Hexafluoride in X-Ray Pulsers. This award category recognizes site greenhouse gas reduction strategies and management approaches that address Scope 1 and 2 emissions.

- Renewable Energy: Implementation of Field-Based Photo Voltaic Charging of Automated Samplers. This award category recognizes outstanding achievements in planning, design, and constructing renewable energy to replace or lower conventional energy consumption.

In addition, in FY 2014, the Laboratory's significant site sustainability successes include the following:

- Completed recommissioning efforts in 12 facilities, including the main campus Otowi building

- Sanitary Effluent Reclamation Facility operations sent over 20 million gallons of recycled water to the Strategic Computing Complex for use within its cooling towers

- Completed building automation system upgrades in two facilities to utilize night set-back energy efficiency features

- Installed two electric vehicle charging stations

- Implemented 33 P2 Projects with 31 projects completed, resulting in a total cost savings to the Laboratory of $\$ 4,852,331$

- Modified major subcontracts that represented the largest significant suppliers of products and services to include Sustainable Acquisition language 
Laboratory management acknowledges the conflict in forecast mission growth and the SSPP energy, water, and GHG reduction goals. The Laboratory will focus efficiency measures within facilities that have a potential to successfully impact energy and water reduction goals and allow the Laboratory to successfully compete for mission growth opportunities. Specifically, to make progress toward the water reduction goals, the Laboratory will continue to operate SERF and implement small reduction projects, but major reductions will not occur given the Laboratory's mission path and the associated increases in supercomputing and Los Alamos Neutron Science Center (LANSCE) accelerator operations.

The Laboratory is also challenged by the impact of footprint reductions on the energy intensity metric. Through FY 2014, LANL has reduced the footprint by over 700k gross square feet (gsf) compared to the FY 2003 baseline year. The reduction in footprint and the operations consolidation have had a greater net effect on the energy intensity data than the associated energy reductions. It is important to capture the net energy reductions and track them separately to see what effect the energy conservation measures have separately from the square footage metric (Figure 2).

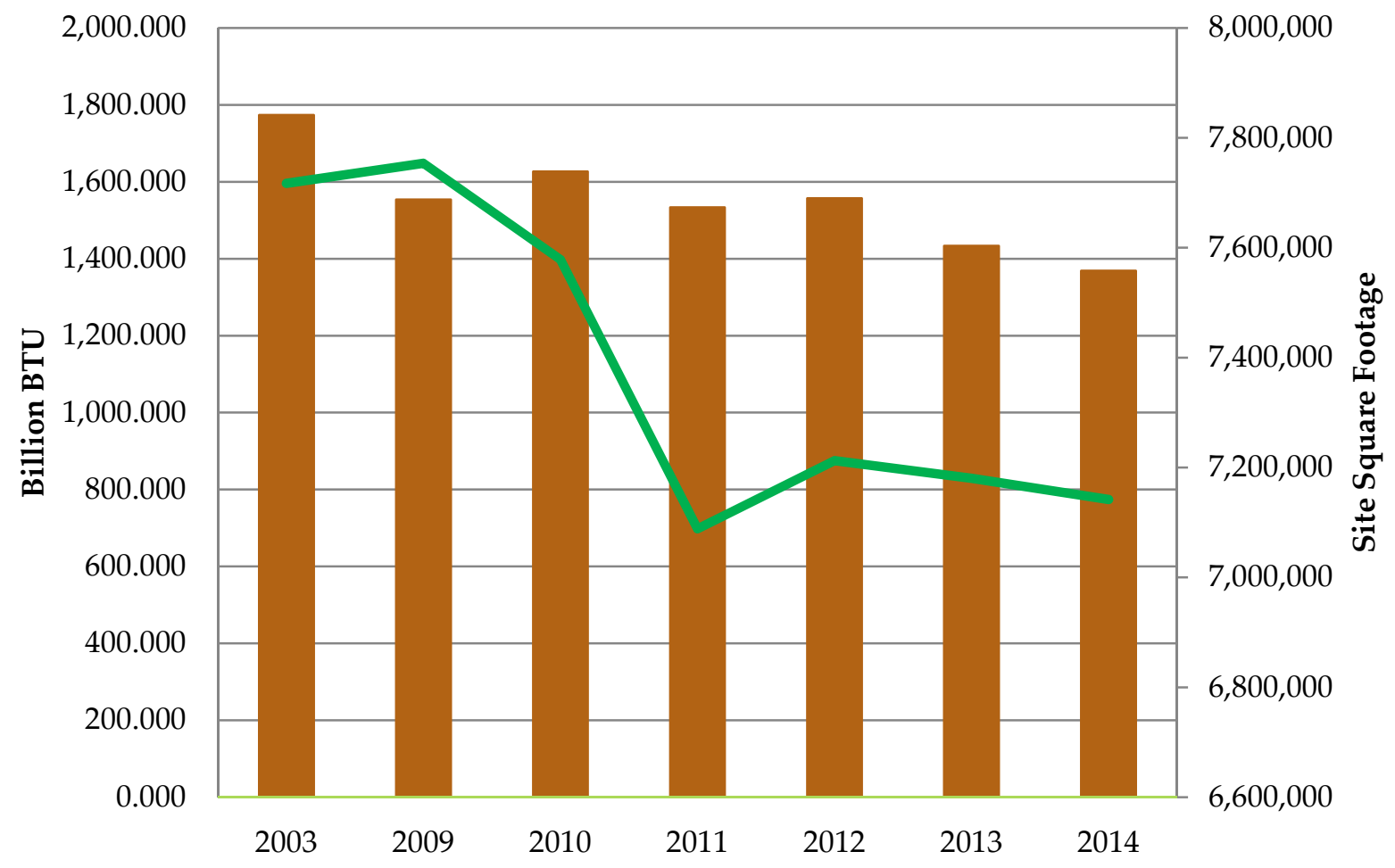

Figure 2. Site Energy Use (orange bars) Compared to Site Growth (green line)

The Laboratory is working to institute cultural change to implement all DOE sustainability goals. Outreach efforts drive cultural change, and this change requires the use of a sustainability lens in all corporate management decisions; planning, executing, evaluating, and improving operations to maximize sustainability and support sound business practices. Table 2 lists a summary of the goal targets for the Laboratory's sustainability efforts. 
Table 2. Site Sustainability Plan Summary Table of Goal Targets

\begin{tabular}{|c|c|c|c|c|}
\hline SSPP Goal \# & DOE Goal & Performance Status through FY 2014 & Planned Actions \& Contribution & $\begin{array}{l}\text { Risk of Non- } \\
\text { attainment }\end{array}$ \\
\hline \multicolumn{5}{|c|}{ GOAL 1: Greenhouse Gas Reduction and Comprehensive Greenhouse Gas Inventory } \\
\hline 1.1 & $\begin{array}{l}28 \% \text { Scope } 1 \& 2 \text { GHG } \\
\text { reduction by FY } 2020 \text { from a } \\
\text { FY } 2008 \text { baseline ( } 2014 \text { target: } \\
19 \%)\end{array}$ & $\begin{array}{l}\text { LANL plans to met this goal. LANL achieved a } \\
19 \% \text { reduction in Scope } 1 \text { \& } 2 \text { GHG emissions } \\
\text { compared to the FY } 2008 \text { baseline due to the } \\
\text { decrease in electricity use on site and } \\
\text { purchase of renewable energy credits. }\end{array}$ & $\begin{array}{l}\text { LANL will continue to pursue lower } \\
\text { carbon electricity resources, as } \\
\text { economically practical, and energy } \\
\text { reduction projects to reduce GHG } \\
\text { emissions and as part of an overall } \\
\text { strategy to maintain the } 28 \% \text { reduction. }\end{array}$ & Low \\
\hline 1.2 & $\begin{array}{l}\text { 13\% Scope } 3 \text { GHG reduction } \\
\text { by FY } 2020 \text { from a FY } 2008 \\
\text { baseline ( } 2014 \text { target: } 5 \%)\end{array}$ & $\begin{array}{l}\text { LANL plans to met this goal. LANL achieved a } \\
25 \% \text { reduction in Scope } 3 \text { GHG emissions } \\
\text { due to decreased air and ground travel and } \\
\text { employee commuting. }\end{array}$ & $\begin{array}{l}\text { LANL recognizes that the most practical } \\
\text { way to reduce Scope } 3 \text { GHG emissions } \\
\text { is by continuing to reduce commuting. } \\
\text { LANL is piloting options for reducing } \\
\text { commuting, e.g., working from home } \\
\text { policies and tax incentives for car- } \\
\text { pooling. }\end{array}$ & Low \\
\hline
\end{tabular}

GOAL 2: Buildings, Energy Savings Performance Contract (ESPC) Initiative Schedule, and Regional \& Local Planning

\begin{tabular}{|l|l|l|l|}
\hline 2.1 & $\begin{array}{l}\text { 30\% energy intensity (Btu per } \\
\text { gross square foot) reduction by } \\
\text { FY 2015 from a FY 2003 } \\
\text { baseline (2014 target: 27\%) }\end{array}$ & $\begin{array}{l}\text { LANL did not meet this goal. In FY 2014, } \\
\text { LANL calculated and tracked a rolling 12- } \\
\text { month energy intensity based on a FY 2003 } \\
\text { baseline. A year-end net energy intensity } \\
\text { reduction of 16\% was reported. }\end{array}$ & $\begin{array}{l}\text { In FY 2015, LANL plans to strategically } \\
\text { invest \$2M to reduce energy } \\
\text { consumption in facilities. This } \\
\text { investment is estimated to yield an } \\
\text { energy reduction percentage of } \\
\text { approximately 3\%. With the same level } \\
\text { of annual investment through FY 2020, } \\
\text { LANL anticipates achieving a } \\
\text { cumulative energy intensity reduction of } \\
\text { 25-30\% compared to the FY 2003 } \\
\text { baseline. }\end{array}$ \\
\hline
\end{tabular}




\begin{tabular}{|c|c|c|c|c|}
\hline SSPP Goal \# & DOE Goal & Performance Status through FY 2014 & Planned Actions \& Contribution & $\begin{array}{l}\text { Risk of Non- } \\
\text { attainment }\end{array}$ \\
\hline 2.2 & $\begin{array}{l}\text { Energy, Independence, and } \\
\text { Security Act Section } 432 \\
\text { energy and water evaluations }\end{array}$ & $\begin{array}{l}\text { LANL met this goal. LANL completed the } \\
\text { EISA07 "covered" facilities energy and water } \\
\text { assessments identified in the 4-year } \\
\text { assessment schedule for FY } 2014 \text {. }\end{array}$ & $\begin{array}{l}\text { LANL will continue to evaluate } \\
\text { "covered" facilities on a 4-year cycle to } \\
\text { identify energy and water conservation } \\
\text { measures and prioritize and implement } \\
\text { energy and water conservation } \\
\text { projects. }\end{array}$ & Low \\
\hline 2.3 & $\begin{array}{l}\text { Individual buildings metering for } \\
90 \% \text { of electricity (by October } \\
1,2012) \text {; for } 90 \% \text { of steam, } \\
\text { natural gas, and chilled water } \\
\text { (by October } 1,2015)^{2}(2014 \\
\text { target: } 90 \% \text { and } 75 \%, \\
\text { respectively) }\end{array}$ & $\begin{array}{l}\text { LANL met this goal. LANL evaluates the } \\
\text { installation of meters using a simple return on } \\
\text { investment calculation based on } 2 \% \text { energy } \\
\text { savings. LANL completed an upgrade to a } \\
\text { new metering software server and migrated all } \\
\text { the metering data to capture energy use in a } \\
\text { new dashboard system. }\end{array}$ & $\begin{array}{l}\text { LANL will re-evaluate required meter } \\
\text { installations when the Federal Energy } \\
\text { Management Program issues new } \\
\text { metering guidance. }\end{array}$ & Low \\
\hline 2.4 & $\begin{array}{l}\text { Cool roofs, unless } \\
\text { uneconomical, for roof } \\
\text { replacements unless project } \\
\text { already has Critical Decision } \\
\text { (CD)-2 approval. New roofs } \\
\text { must have thermal resistance } \\
\text { of at least R-303 }\end{array}$ & $\begin{array}{l}\text { LANL met this goal. All new roofs meet cool } \\
\text { roof requirements per engineering standards. } \\
\text { In FY 2014, there was } 36,000 \text { square feet of } \\
\text { cool roofing installed. }\end{array}$ & $\begin{array}{l}\text { LANL plans the replacement of approx. } \\
66,000 \text { square feet of roof for } 2015 \text {. } \\
\text { Every roof will be replaced within the } \\
\text { parameters established at an R-value } \\
\text { of } 30 \text { or above and the membranes will } \\
\text { meet the cool roof initiatives. }\end{array}$ & Low \\
\hline
\end{tabular}

2 Per NECPA (42 U.S.C Section 8253), the term “buildings" includes industrial, process, or laboratory facilities.

3 Secretary of Energy Dr. Steven Chu, Installation of Cool Roofs on Department of Energy Buildings, Memorandum for Heads of Departmental Elements, June 1, 2010. 


\begin{tabular}{|c|c|c|c|c|}
\hline SSPP Goal \# & DOE Goal & Performance Status through FY 2014 & Planned Actions \& Contribution & $\begin{array}{l}\text { Risk of Non- } \\
\text { attainment }\end{array}$ \\
\hline 2.5 & $\begin{array}{l}15 \% \text { of existing buildings } \\
\text { greater than } 5,000 \text { gross } \\
\text { square feet (GSF) are } \\
\text { compliant with the Guiding } \\
\text { Principles (GPS) of HPSB by } \\
\text { FY } 2015(2014 \text { target: } 13 \%)\end{array}$ & $\begin{array}{l}\text { LANL did not meet this goal. LANL has an } \\
\text { average } 65 \% \text { Guiding Principle } \\
\text { implementation rate within the selected } 31 \\
\text { HPSBs. In FY 2014, LANL completed } \\
\text { recommissioning activities in } 8 \text { HPSBs. }\end{array}$ & $\begin{array}{l}\text { LANL plans to continue implementing } \\
\text { the Guiding Principles within selected } \\
\text { HPSBs focusing on HVAC and BAS } \\
\text { recommissioning. LANL is investing } \\
\text { approximately } \$ 1.3 \mathrm{M} \text { in HPSBs in FY } \\
2015 \text { as part of the overall funding to } \\
\text { reduce energy use in facilities. The risk } \\
\text { of non-attainment is high because } \\
\text { LANL will focus on high ROI energy } \\
\text { reduction in order to also make } \\
\text { progress in energy intensity reduction. }\end{array}$ & High \\
\hline 2.6 & $\begin{array}{l}\text { All new construction, major } \\
\text { renovations, and alterations of } \\
\text { buildings greater than } 5,000 \\
\text { GSF must comply with the } \\
\text { GPs } 4\end{array}$ & $\begin{array}{l}\text { LANL met this goal. DOE provided on-site } \\
\text { LEED training to over } 20 \text { LANL employees } \\
\text { including the TRU Waste Facility project } \\
\text { management team. The TRU Waste Facility } \\
\text { design projects a LEED platinum facility. }\end{array}$ & $\begin{array}{l}\text { Over } 600,000 \text { square feet of major new } \\
\text { projects, currently in the planning } \\
\text { stages are being formulated to be } \\
\text { certified as LEED Gold projects. LANL } \\
\text { will continue to implement and manage } \\
\text { efforts to address the requirement for } \\
\text { achieving LEED Gold and the } 35 \% \\
\text { improvement over ASHRAE } \\
\text { requirement for new projects using cost } \\
\text { effective capital outlay strategies to } \\
\text { achieve long-range operational } \\
\text { benefits. }\end{array}$ & Low \\
\hline
\end{tabular}

4 DOE considers buildings meeting the following criteria as complying with GPs: any building that achieves Leadership in Energy and Environment Design (LEED)-Existing Buildings (EB) Silver or higher or LEED-New Construction (NC) Gold or higher; any building that achieves a Green Globes-NC rating of four or a Green Globes Continual Improvement for Existing Buildings (CIEB) rating of three; any building that has been occupied for more than one year that achieves Living Status designation by the Living Building Challenge. (Although included as policy in the 2012 SSPP, these equivalencies are contingent on Office of Management and Budget (OMB) and Council on Environmental Quality (CEQ) approval.) 


\begin{tabular}{|c|c|c|c|c|}
\hline SSPP Goal \# & DOE Goal & Performance Status through FY 2014 & Planned Actions \& Contribution & $\begin{array}{l}\text { Risk of Non- } \\
\text { attainment }\end{array}$ \\
\hline 2.7 & $\begin{array}{l}\text { Efforts to increase regional and } \\
\text { local planning coordination and } \\
\text { involvement }\end{array}$ & \multicolumn{3}{|c|}{$\begin{array}{l}\text { The Laboratory sponsors and engages interactive and ongoing relationships with all neighbors to promote } \\
\text { common goals and interest, as well as resolving cross-jurisdictional issues. The Laboratory participates as } \\
\text { a positive partner in many community efforts and, as a large stakeholder, has the ability to bring diverse } \\
\text { entities together in a common effort. }\end{array}$} \\
\hline \multicolumn{5}{|c|}{ GOAL 3: Fleet Management } \\
\hline 3.1 & $\begin{array}{l}10 \% \text { annual increase in fleet } \\
\text { alternative fuel consumption by } \\
\text { FY } 2015 \text { relative to a FY } 2005 \\
\text { baseline ( } 2014 \text { target: } 136 \% \\
\text { cumulative since } 2005)\end{array}$ & $\begin{array}{l}\text { LANL met this goal. In FY } 2014 \text {, alternative } \\
\text { fuel consumption was } 86,754 \text { gallons, which is } \\
\text { an } 876 \% \text { increase compared to the FY } 2005 \\
\text { baseline. }\end{array}$ & $\begin{array}{l}\text { LANL will continue to purchase and } \\
\text { increase utilization of alternative fuel for } \\
\text { vehicles using E-85 and B-5 in FY } \\
2015 .\end{array}$ & Low \\
\hline 3.2 & $\begin{array}{l}2 \% \text { annual reduction in fleet } \\
\text { petroleum consumption by FY } \\
2020 \text { relative to a FY } 2005 \\
\text { baseline ( } 2014 \text { target: } 18 \% \\
\text { cumulative since } 2005 \text { ) }\end{array}$ & $\begin{array}{l}\text { LANL met this goal. LANL decreased its fleet } \\
\text { petroleum use in FY } 2014 \text { by } .05 \% \text { compared } \\
\text { to FY } 2013 \text { usage and reduced fleet } \\
\text { petroleum use by } 21 \% \text { compared to a FY } \\
2005 \text { baseline. }\end{array}$ & $\begin{array}{l}\text { LANL will continue to right-size the fleet } \\
\text { and expand alternative fuel use to } \\
\text { reduce petroleum consumption. }\end{array}$ & Low \\
\hline 3.3 & $\begin{array}{l}\text { 100\% of light duty vehicle } \\
\text { (LDV) purchases must consist } \\
\text { of alternative fuel vehicles } \\
\text { (AFV) by FY } 2015 \text { and } \\
\text { thereafter ( } 75 \% \text { FY } 2000- \\
2015) .5 \text { (For MSAareas.) }\end{array}$ & $\begin{array}{l}\text { Los Alamos is not located in a Metropolitan } \\
\text { Statistical Area (MSA). LANL's total fleet } \\
\text { consists of } 1,546 \text { vehicles, of which } 772 \text { or } \\
49 \% \text { of those are considered LDVs. Of the } \\
772 \text { LDVs, } 549 \text { or } 71 \% \text { are AFVs. }\end{array}$ & $\begin{array}{l}\text { LANL will continue to replace vehicles } \\
\text { with AFVs as economically practicable. }\end{array}$ & Low \\
\hline
\end{tabular}

5 EPAct 1992 goal updated per Presidential Memorandum on Federal Fleet Performance on May 24, 2011: http://www.whitehouse.gov/the-pressoffice/2011/05/24/presidential-memorandum-federal-fleet-performance 


\begin{tabular}{|c|c|c|c|c|}
\hline SSPP Goal \# & DOE Goal & Performance Status through FY 2014 & Planned Actions \& Contribution & $\begin{array}{l}\text { Risk of Non- } \\
\text { attainment }\end{array}$ \\
\hline \multicolumn{5}{|c|}{ GOAL 4: Water Use Efficiency and Management } \\
\hline 4.1 & $\begin{array}{l}26 \% \text { potable water intensity } \\
\text { (gal. per gross square foot) } \\
\text { reduction by FY } 2020 \text { from a } \\
\text { FY } 2007 \text { baseline ( } 2014 \text { target: } \\
14 \%)\end{array}$ & $\begin{array}{l}\text { LANL does not plan to meet this goal. In FY } \\
2014 \text { LANL's water use reduction was } \\
\text { dependent on SERF operations and industrial } \\
\text { water reuse at the SCC. LANL's total water } \\
\text { use in FY } 2014 \text { was approximately } 307 \text { million } \\
\text { gallons, } 80 \text { million gallons less than last year. } \\
\text { Water intensity has decreased by } \\
\text { approximately 3\% compared to the FY } 2007 \\
\text { baseline. }\end{array}$ & $\begin{array}{l}\text { In FY } 2015 \text { SERF operations will avoid } \\
\text { consumption of potable water in the } \\
\text { SCC operations. LANL's sustainability } \\
\text { efforts will focus on small, targeted } \\
\text { water conservation measures that } \\
\text { dovetail with site infrastructure } \\
\text { upgrades and also emphasizing energy } \\
\text { efficiency to reduce LANL's regional } \\
\text { impact on water use associated with } \\
\text { energy generation. In FY } 2015 \text { LANL } \\
\text { plans to maintain water consumption at } \\
\text { or below FY } 2014 \text { levels. }\end{array}$ & High \\
\hline 4.2 & $\begin{array}{l}20 \% \text { water consumption (gal.) } \\
\text { reduction of industrial, } \\
\text { landscaping, and agricultural } \\
\text { (ILA) water by FY } 2020 \text { from a } \\
\text { FY } 2010 \text { baseline ( } 2014 \text { target: } \\
8 \%)\end{array}$ & $\begin{array}{l}\text { Currently, all of LANL's water use is potable } \\
\text { water and is, therefore, considered part of the } \\
26 \% \text { water intensity reduction goal reporting. }\end{array}$ & $\begin{array}{l}\text { LANL will not report on the ILA goal but } \\
\text { will focus efforts in total potable water } \\
\text { intensity reduction as described above. }\end{array}$ & N/A \\
\hline \multicolumn{5}{|c|}{ GOAL 5: Pollution Prevention and Waste Reduction } \\
\hline 5.1 & $\begin{array}{l}\text { Divert at least } 50 \% \text { of non- } \\
\text { hazardous solid waste, } \\
\text { excluding construction and } \\
\text { demolition debris, by FY } 2015\end{array}$ & $\begin{array}{l}\text { LANL met this goal. In FY 2014, LANL } \\
\text { diverted } 54 \% \text { of solid, non-hazardous waste. }\end{array}$ & $\begin{array}{l}\text { LANL will continue to identify and } \\
\text { implement opportunities for } \\
\text { improvement in non-hazardous solid } \\
\text { waste recycling / diversion in FY } 2015 .\end{array}$ & Low \\
\hline 5.2 & $\begin{array}{l}\text { Divert at least } 50 \% \text { of } \\
\text { construction and demolition } \\
\text { materials and debris by FY } \\
2015\end{array}$ & $\begin{array}{l}\text { LANL met this goal. In FY 2014, LANL } \\
\text { recycled or diverted } 93 \% \text { of construction and } \\
\text { demolition waste. }\end{array}$ & $\begin{array}{l}\text { LANL will continue diverting } \\
\text { construction and demolition waste in FY } \\
2015 \text {. }\end{array}$ & Low \\
\hline
\end{tabular}




\begin{tabular}{|c|c|c|c|c|}
\hline SSPP Goal \# & DOE Goal & Performance Status through FY 2014 & Planned Actions \& Contribution & $\begin{array}{l}\text { Risk of Non- } \\
\text { attainment }\end{array}$ \\
\hline \multicolumn{5}{|c|}{ GOAL 6: Sustainable Acquisition } \\
\hline 6.1 & $\begin{array}{l}\text { Procurements meet } \\
\text { requirements by including } \\
\text { necessary provisions and } \\
\text { clauses in } 95 \% \text { of applicable } \\
\text { contracts }\end{array}$ & $\begin{array}{l}\text { In FY 2014, LANS ensured that the } \\
\text { sustainable acquisition clause language was } \\
\text { included in the LANL's Food Services contract } \\
\text { extension. This contract extension will cover } \\
\text { the next one to two years as LANL prepares } \\
\text { to issue a new RFP at that time. }\end{array}$ & $\begin{array}{l}\text { In FY } 2015 \text { LANL will continue to strive } \\
\text { to increase its procurement of } \\
\text { environmentally preferable products } \\
\text { while simultaneously increasing its } \\
\text { visibility of those procurements and the } \\
\text { associated reporting capability. }\end{array}$ & Medium \\
\hline \multicolumn{5}{|c|}{ GOAL 7: Electronic Stewardship and Data Centers } \\
\hline 7.1 & $\begin{array}{l}\text { All data centers are metered to } \\
\text { measure a monthly Power } \\
\text { Use/Utilization Effectiveness } \\
\text { (PUE) of } 100 \% \text { by FY } 2015 \\
\text { (2014 target: } 90 \% \text { ) }\end{array}$ & $\begin{array}{l}\text { LANL did not meet this goal. LANL has } \\
\text { identified } 3 \text { CORE data centers: the Strategic } \\
\text { Computing Complex (SCC), Laboratory Data } \\
\text { Communications Center (LDCC), and the } \\
\text { Central Computing Facility (CCF). All three } \\
\text { facilities have electric meters that feed } \\
\text { information to our main metering database. } \\
\text { The SCC and LDCC have advanced PUE } \\
\text { monitoring systems. }\end{array}$ & $\begin{array}{l}\text { Energy use in the SCC and the LDCC } \\
\text { is equivalent to about } 87 \% \text { of the } \\
\text { energy used in data centers on site. } \\
\text { The CCF PUE is calculated. Energy } \\
\text { use in the CCF is equivalent to about } \\
8 \% \text { of the energy used in data centers. } \\
\text { No action is planned in FY } 2015 \\
\text { pending upgrades in the CCF that may } \\
\text { include a PUE monitoring system. }\end{array}$ & High \\
\hline 7.2 & $\begin{array}{l}\text { Maximum annual weighted } \\
\text { average PUE of } 1.4 \text { by FY } \\
2015 \text { (2014 target: } 1.5)\end{array}$ & $\begin{array}{l}\text { LANL did not meet this goal. The PUE at the } \\
\text { SCC is currently averaging } 1.56 \text { and the PUE } \\
\text { at the LDCC is averaging at } 1.57 \text {. The Central } \\
\text { Computing Facility (CCF) estimated PUE is } \\
\text { 1.47. The FY } 2014 \text { annual weighted average } \\
\text { PUE for all three major data centers is } 1.55 \text {. }\end{array}$ & $\begin{array}{l}\text { LANL is planning to upgrade the SCC } \\
\text { with Trinity beginning in } 2016 \text {. The } \\
\text { planned PUE for Trinity will be } \\
\text { approximately } 1.2 \text {. With this upgrade, } \\
\text { LANL will meet the PUE goal of } 1.4 \text {, but } \\
\text { most likely not until FY } 2016 \text { after } \\
\text { Trinity comes online. }\end{array}$ & Medium \\
\hline 7.3 & $\begin{array}{l}\text { Power Management: } 100 \% \text { of } \\
\text { eligible PCs, laptops, and } \\
\text { management actively } \\
\text { implemented and in use by FY } \\
2012\end{array}$ & $\begin{array}{l}\text { LANL met this goal. In FY 2014, LANL } \\
\text { continued to implement power management of } \\
\text { Windows desktops and laptops. }\end{array}$ & $\begin{array}{l}\text { In FY 2015, LANL will continue use of } \\
\text { the power management of Windows } \\
\text { desktops and laptops on eligible } \\
\text { systems. }\end{array}$ & Low \\
\hline
\end{tabular}




\begin{tabular}{|c|c|c|c|c|}
\hline SSPP Goal \# & DOE Goal & Performance Status through FY 2014 & Planned Actions \& Contribution & $\begin{array}{l}\text { Risk of Non- } \\
\text { attainment }\end{array}$ \\
\hline 7.4 & $\begin{array}{l}\text { Electronic Stewardship: } 95 \% \text { of } \\
\text { eligible electronics acquisitions } \\
\text { meet EPEAT standards }\end{array}$ & $\begin{array}{l}\text { In FY2014 LANL reviewed and prioritized four } \\
\text { subcontract areas to address this goal } \\
\text { including Electrical/Information Technology } \\
\text { Hardware. }\end{array}$ & $\begin{array}{l}\text { LANL will complete an analysis of } \\
\text { existing service subcontracts that } \\
\text { potentially supply energy-affecting } \\
\text { repair parts and make similar efforts to } \\
\text { modify or plan for the eventual } \\
\text { modification of those subcontracts to } \\
\text { provide acquisition data that covers all } \\
\text { procurement mechanisms. }\end{array}$ & Low \\
\hline \multicolumn{5}{|c|}{ GOAL 8: Renewable Energy } \\
\hline 8.1 & $\begin{array}{l}20 \% \text { of annual electricity } \\
\text { consumption from renewable } \\
\text { sources by FY } 2020 \text { (2014 } \\
\text { target: } 7.5 \%)\end{array}$ & $\begin{array}{l}\text { LANL exceeded the } 7.5 \% \text { renewable energy } \\
\text { goal in FY 2014. The Laboratory used } \\
\text { approximately } 386,000 \text { MWh of electricity in } \\
\text { FY } 2014 \text { including onsite renewable } \\
\text { generation. The purchased renewable energy } \\
\text { credit amount }(27,000 \mathrm{MWh} \text { ) in addition to } \\
\text { onsite renewable energy amounts to } 12 \% \text { of } \\
\text { the annual electricity consumption. }\end{array}$ & $\begin{array}{l}\text { LANL will continue to purchase RECs } \\
\text { and utilize the on-site renewable } \\
\text { sources, such as the Abiquiu dam low- } \\
\text { flow turbine, to meet this goal. In } \\
\text { addition, LANL is requesting an update } \\
\text { to the } 2008 \text { Renewable Energy } \\
\text { feasibility study through the Federal } \\
\text { Energy Management Program to } \\
\text { explore additional renewable } \\
\text { investments. }\end{array}$ & Low \\
\hline \multicolumn{5}{|c|}{ GOAL 9: Climate Change Resilience } \\
\hline 9.1 & $\begin{array}{l}\text { Address DOE Climate Change } \\
\text { Adaptation Plan goals }\end{array}$ & \multicolumn{3}{|c|}{$\begin{array}{l}\text { The Laboratory has initiated a new comprehensive site planning process, partly in recognition that climatic } \\
\text { events have had significant negative impacts on operations and infrastructure since the last comprehensive } \\
\text { site plan in } 2000 \text {. The intent is to provide a vision for Laboratory operations and infrastructure for a } 25 \text { to } 30 \\
\text { year planning horizon. Such planning will now include processes, procedures, and policies to account for } \\
\text { climate change impacts. }\end{array}$} \\
\hline
\end{tabular}




\begin{tabular}{|c|c|c|c|c|}
\hline SSPP Goal \# & DOE Goal & Performance Status through FY 2014 & Planned Actions \& Contribution & $\begin{array}{l}\text { Risk of Non- } \\
\text { attainment }\end{array}$ \\
\hline \multicolumn{5}{|c|}{ GOAL 10: Energy Performance Contracts } \\
\hline 10.1 & $\begin{array}{l}\text { Utilization of Energy } \\
\text { Performance Contracts }\end{array}$ & \multicolumn{3}{|c|}{$\begin{array}{l}\text { LANL has begun the planning process to upgrade a nominal 23-megawatt combustion utilizing an Energy } \\
\text { Savings Performance Contract and is waiting for a response on the proposal from the Los Alamos Site } \\
\text { Office. The upgrade would modify the turbine into a high-efficiency, dual-cycle unit with a steam turbine as } \\
\text { the second cycle. Steam will also be extracted from the turbine when needed to power a refurbished campus } \\
\text { heating system in a cogeneration mode. In addition, LANL is pursuing an upgrade to the } 2008 \text { Renewable } \\
\text { Energy Feasibility Study through the Federal Energy Management Program to develop a solar energy scope } \\
\text { of work for an Energy Savings Performance Contract. }\end{array}$} \\
\hline
\end{tabular}




\title{
PERFORMANCE REVIEW AND PLAN NARRATIVE
}

\author{
GOAL 1: GREENHOUSE GAS REDUCTION AND COMPREHENSIVE \\ GREENHOUSE GAS INVENTORY
}

\section{8\% SCOPE 1 \& 2 GHG REDUCTION BY FY 2020 FROM A FY 2008 BASELINE}

\section{Performance Status}

LANL has achieved a 19\% reduction in Scope 1 \& 2 GHG emissions compared to the FY 2008 baseline largely through reductions in electricity use and purchases of renewable energy credits (RECs). In FY 2014, LANL purchased 27,000 MWhr RECs. LANL reduced its energy use from 1,443,459 Million British Thermal Units (MBTU) in FY 2013 to 1,368,677 in FY 2014. The funded energy reduction projects mainly contribute to Scope 2 greenhouse gas emissions reductions. However, LANL's energy use is expected to steadily increase over the next 10 years as computing requires additional electricity and expanded programmatic activities at LANSCE consume greater quantities of power.

During FY 2014, LANL funded a project to reduce sulfur hexafluoride emissions from its turbulence lab. This is a multi-year project, and in FY 2014, the project team began the engineering design and modeling to determine if new equipment could be installed to capture and reuse the mixture of air and sulfur hexafluoride required for the experiments. If successful, project leaders expect to reduce emissions of the sulfur hexafluoride and air mixture by over $2,000 \mathrm{~kg}$ annually.

Upgrades to facilities are critical in order to meet the energy efficiency goal and reduce greenhouse gas emissions. The J.R. Oppenheimer Building, also called the Study Center, was recently remodeled and upgraded to host a newly designed Collaboration Space (Figure 3). Located on the first floor of the Study Center at TA-3, the Collaboration Space's central location and strategic design makes it an ideal space for collaborative initiatives that reach across disciplines, organizations, and functions to develop innovative solutions that enable Laboratory missions. This space also serves as an alternative workplace and optimizes existing space at the Laboratory. Plans to upgrade the second floor are underway. The upgrade also included all new Light Emitting Diode (LED) lighting for energy efficiency.

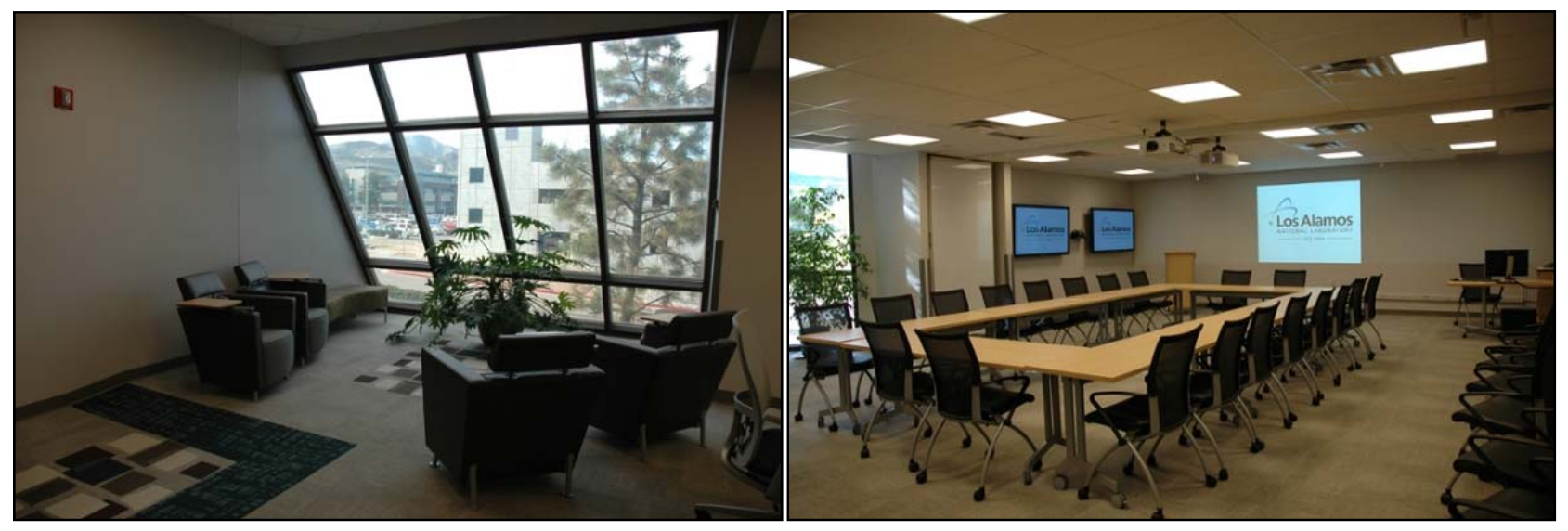

Figure 3. Upgrades to Study Center

\section{Projected Performance}

LANL is interested in exploring a number of initiatives to meet the GHG emissions reduction goals. Based on the major contributors to GHG, LANL plans on reducing GHG from heating by improving the efficiency of the on-site central heating and distribution system. One option includes improving the overall efficiency by 
adding a second cycle on the combustion turbine and using cogeneration to produce heat for the Technical Area (TA)-3 complex. LANL has begun this planning process to upgrade the nominal 23-megawatt combustion turbine it currently uses as a backup generator resource. The upgrade would modify the turbine into a high-efficiency, dual-cycle unit with a steam turbine as the second cycle. Steam will also be extracted from the turbine when needed to power a refurbished campus heating system in a cogeneration mode. The new unit will be operated as a base-load machine and will provide 31 megawatts on average; its net effect will be to meet the growing demand of LANL's high-performance computing program with a lower carbon resource than is currently available in the New Mexico region rather than displacing current generation. The revitalized central heating system is tied with upgrades to several older facilities as part of the Lab's Long Range Development Plan that will improve the energy efficiency of the building HVAC systems. LANL is exploring the financing mechanisms to support this project and also provided a proposal to NNSA to complete the work using an Energy Savings Performance Contract. Table 3 shows greenhouse gas emissions avoided by upgrading to a combined heat and power plant.

Table 3. Potential Greenhouse Gas Emission Savings

\begin{tabular}{|l|c|c|c|}
\hline $\begin{array}{c}\text { Meeting the Same Energy } \\
\text { Demand: }\end{array}$ & $\begin{array}{c}\text { Primary Energy } \\
\text { Consumed } \\
\text { (Billion Btu/Yr.) }\end{array}$ & $\begin{array}{c}\text { Effective Use Of } \\
\text { Primary Energy } \\
\text { (Percent) }\end{array}$ & $\begin{array}{c}\text { Greenhouse Gas } \\
\text { Generated } \\
\text { (Metric Tons } \\
\text { Co2/Yr.) }\end{array}$ \\
\hline Continue on Current Path & 3,400 & $31.4 \%$ & 312,000 \\
\hline $\begin{array}{l}\text { Proposed Combined Heat and } \\
\text { Power Upgrade }\end{array}$ & 2,000 & $53.8 \%$ & 106,000 \\
\hline
\end{tabular}

In addition to improved efficiency, LANL plans to reduce GHG from electrical energy by either purchasing RECs to replace fossil-fuel-dependent energy or focusing on a power purchase agreement (PPA) for lower or no carbon-producing energy in order to change its generation mix to reduce the carbon footprint of electricity supplies. LANL's projections show that these initiatives will bring its carbon emissions to approximately $70 \%$ of the FY 2008 baseline, even though in the same period electrical consumption will grow by $135 \%$ (Figure 4). One option under consideration is contracting for renewable power as the source of supply after the point in time when the generation owned by the Los Alamos County cannot meet the demand. LANL is requesting an update to the 2008 Renewable Energy Feasibility Study through the Federal Energy Management Program in order to propose further onsite renewable investments. Power generated in the NM-AZ region is $60 \%$ coal-fired, and it is anticipated that either onsite renewable resources or a PPA would displace open market purchases largely generated in regional coal-fired plants. 


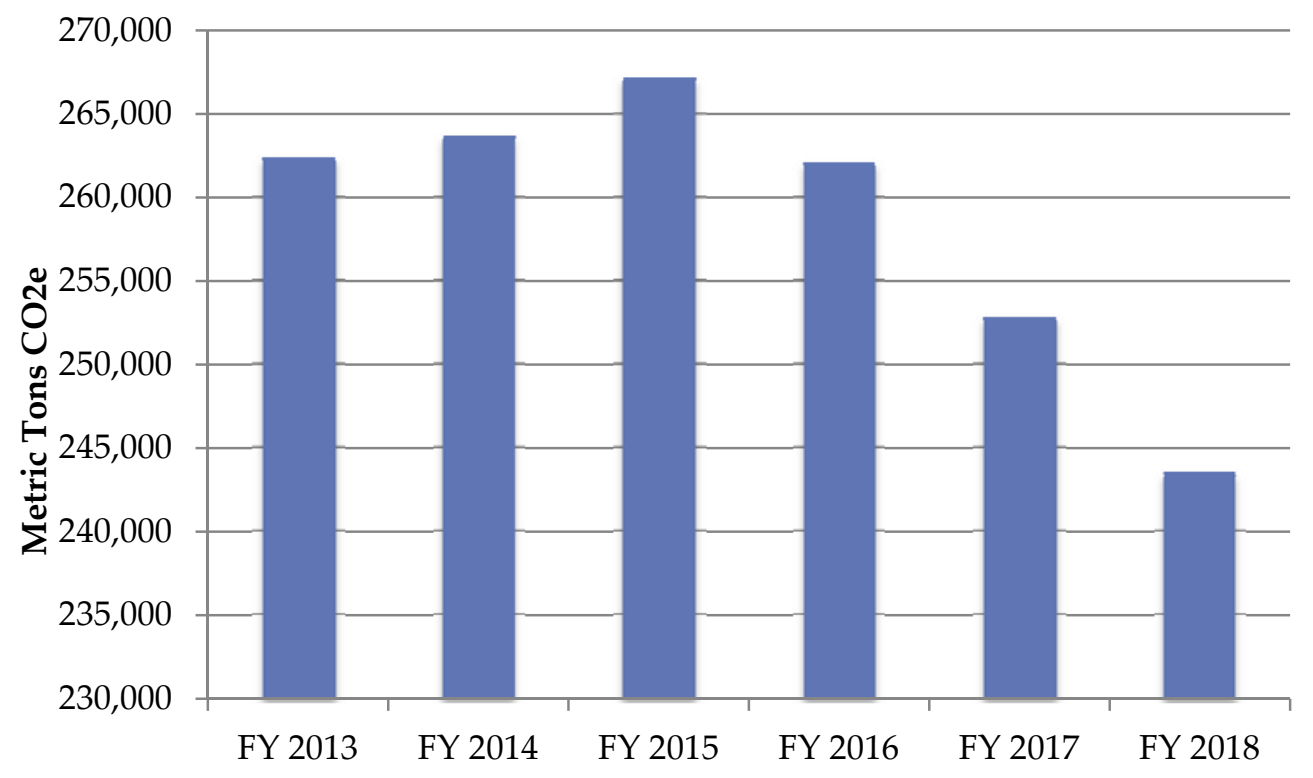

Figure 4. Five-Year Direct Carbon Dioxide Equivalent (C02e) Emissions Projection

\section{3\% SCOPE 3 GHG REDUCTION BY FY 2020 FROM A FY 2008 BASELINE}

\section{Performance Status}

LANL has achieved a reduction of $26 \%$ in Scope 3 GHG emissions due to decreased air and ground travel and employee commuting compared to the FY 2008 baseline year. In FY 2014, LANL performed its second statistical commuting survey, and overall commuting patterns were similar to those found during FY 2013. LANL plans to focus on further reducing commuting to reduce Scope 3 GHG emissions through work schedule modification, telecommuting, or workplace relocations. In addition to GHG reductions, telecommuting may also contribute to a reduction in infrastructure operating costs, enable LANL's footprint reduction initiative, and improve employee work/life benefits.

LANL is working with its information technology and cyber security infrastructure to ensure that work-from-home policies and technologies are available and in place. LANL is reviewing work-from-home options since nearly all other federal sites have telecommuting or flexible workplace options available to workers, and responses to the commuting survey indicated that workers are very interested in telecommuting.

LANL maintains and allows public access to a central transit station facility within TA-3 on NNSA property. This central station allows three transit systems to converge at this point: the Laboratory taxi and bus system, the County of Los Alamos Atomic City Transit, and the State of New Mexico's Department of Transportation Park and Ride that contracts with All-Aboard America to provide a regional bus service. The County's Atomic City Transit provides transportation from the community of White Rock at the southeast edge of Los Alamos County, to the Los Alamos town site at the north end of the county, and within these communities.

Employee commuting contributes the largest percentage to Scope 3 GHG emissions at LANL, and supporting data are located within the attached CEDR. Prior to 2008 and the establishment of the FY 2008 baseline, LANL implemented a 9/80 schedule, which gave employees the option to work 80 hours during nine days in 
a two-week period. This schedule option allowed employees to cut their commute distance and time by 10 percent. About $70 \%$ of the LANL workforce is on the $9 / 80$ schedule.

Mass transit to LANL via bus has been expanded from the surrounding communities of Santa Fe and Española and also within Los Alamos and White Rock. In addition, the Rail Runner train provides employees from the Albuquerque area the option to connect with buses from Santa Fe to Los Alamos instead of driving personal vehicles. LANL provides taxi service for employees to travel between sites during the day so that fewer people require their personal vehicles. For many years, LANL has organized a special section on its internal website to connect potential carpoolers with each other.

There was slightly more business air travel at LANL in FY 2014 compared with FY 2013. Business use of rental cars was also slightly higher in FY 2014 compared with FY 2013. Many divisions within LANL restricted travel significantly since FY 2012 due to budget cuts. Eliminating travel and using video or teleconferencing when possible was one of the easiest ways for divisions to cut costs.

Employees in LANL leased space utilize a County-owned wastewater treatment plant with aerobic and denitrification treatment. LANL operates its own centralized wastewater treatment plant. The GHG emissions from the LANL plant are related to the number of employees working at LANL.

LANL has actively participated in pollution prevention for about two decades, and one of the targets has always been to reduce the volume of municipal solid waste generated at LANL. All municipal solid waste from LANL is disposed of off site. In FY 2014, there was a special emphasis placed on office and lab cleanouts throughout the Laboratory, and this resulted in greater waste generation than during FY 2013. Many kinds of unwanted materials can be recycled at LANL, including toner cartridges, aluminum cans, plastic bottles, brush, paper, asphalt, concrete, and cardboard.

\section{Projected Performance}

LANL is working to evaluate the cost-benefit of telecommuting and other options to reduce overall employee commuting. Depending on the number of additional employees who were allowed to telecommute, miles driven and GHG emissions from commuting would drop accordingly. Reducing the number of miles commuted by LANL employees would make the most significant reduction to Scope 3 GHG emissions since commuting contributed over $80 \%$ of the Scope 3 GHG emissions at LANL in FY 2014. LANL plans to conduct a statistical commuting survey annually to track changes in commuting behavior over time.

To a lesser extent, other ongoing activities will also reduce Scope 3 greenhouse gas emissions. GHG emissions from municipal solid waste and offsite and onsite wastewater treatment make up a very small fraction of LANL's Scope 3 emissions. LANL's recycling programs are ongoing, and the Pollution Prevention team is always looking for new ways to minimize the amount of municipal solid waste that is generated onsite. Recycling as much as possible will reduce GHG emissions related to municipal solid waste generation.

In addition, LANL is using a new instant messaging and desktop teleconferencing system called Lync. Using the Lync system can reduce travel on site and has the potential to preclude long-distance travel with advanced video teleconferencing and web meeting capabilities.

\section{GOAL 2: BUILDINGS, ESPC INITIATIVE SCHEDULE, AND REGIONAL \& LOCAL PLANNING}

$30 \%$ ENERGY INTENSITY (BTU/GSF) REDUCTION BY FY 2015 FROM A FY 2003 BASELINE

\section{Performance Status}


Between FY 2003 and FY 2014, LANL reduced its cumulative energy intensity by 16\%. In FY 2003, LANL used 227,880 BTUs/sq. ft., and in FY 2014, LANL used 192,225 BTUs/sq. ft. Figure 5 shows the Laboratory's energy intensity by fiscal year.

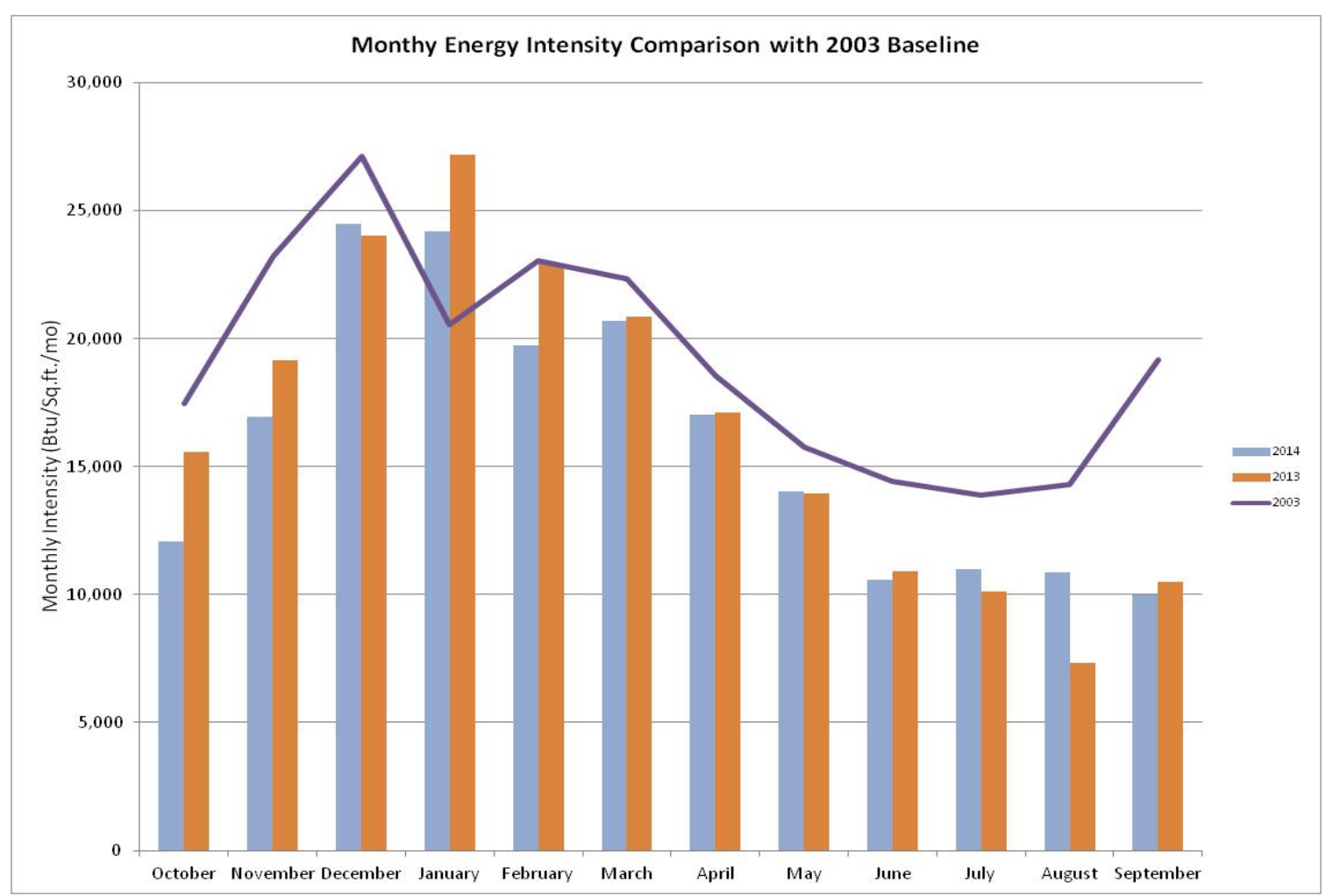

Figure 5. Monthly Energy Intensity Comparison with 2003 Baseline (BTU/sq. ft./month)

LANL has invested in a number of energy reduction initiatives in FY 2014 including BAS repairs and upgrades, implementing night setback schedules, and recommissioning in HPSB facilities, which has reduced energy use in some facilities by up to 50\%. LANL also completed an ESPC in 2012 and upgraded existing HVAC and lighting at several facilities and was estimated to reduce the energy in Goal-Target facilities by about 65,000 Million BTUs (MBTU) per year.

LANL is working to develop a broader set of metrics for maintenance and operations staff to improve understanding of the site's energy use and reduction performance. The proposed new metrics, such as night setback implementation and cooling tower cycles of concentration, will provide a more detailed view of progress toward accomplishing the sustainability goals.

LANL has made strong progress to improve effective use of energy as shown on an energy per mission dollar and energy per capita basis. Figure 6 details the Laboratory's total energy use divided by the total operational budget of the site, and Figure 7 details the site's total energy use divided by the total operational staff on site. Due to the decrease in energy use and staff, a decline is shown in both graphs. 


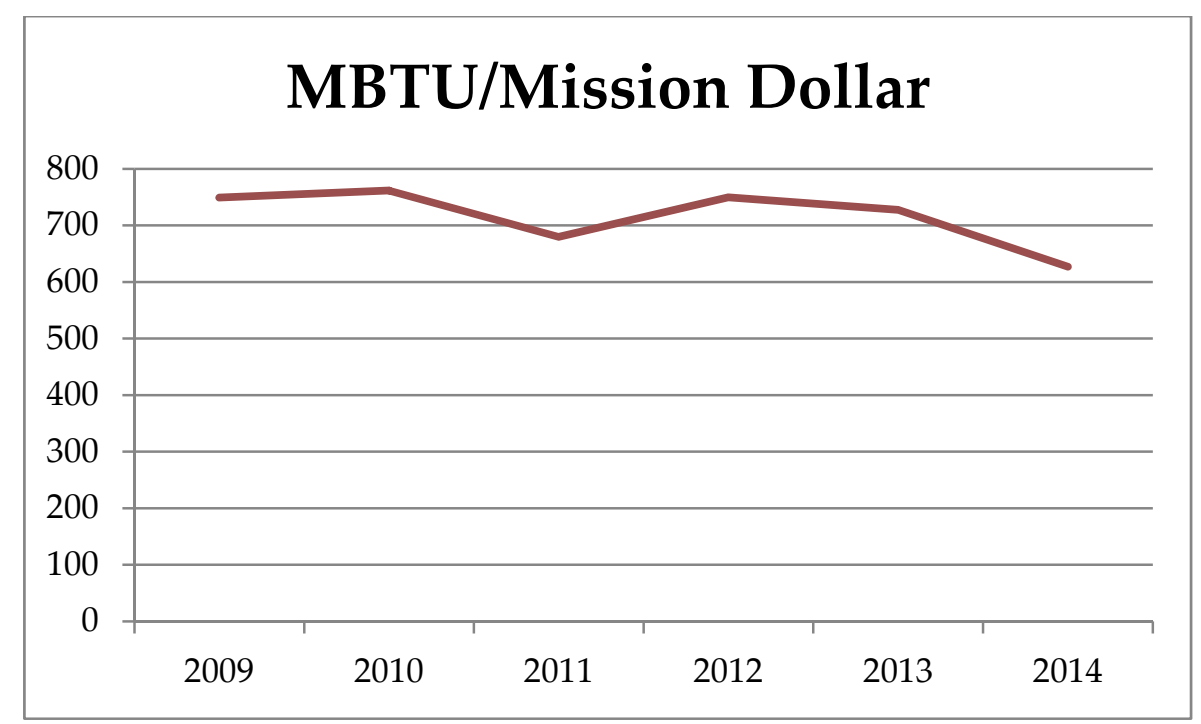

Figure 6. Site's Total Energy Use Divided by Total Operational Budget of Site (MBTU/mission dollar)

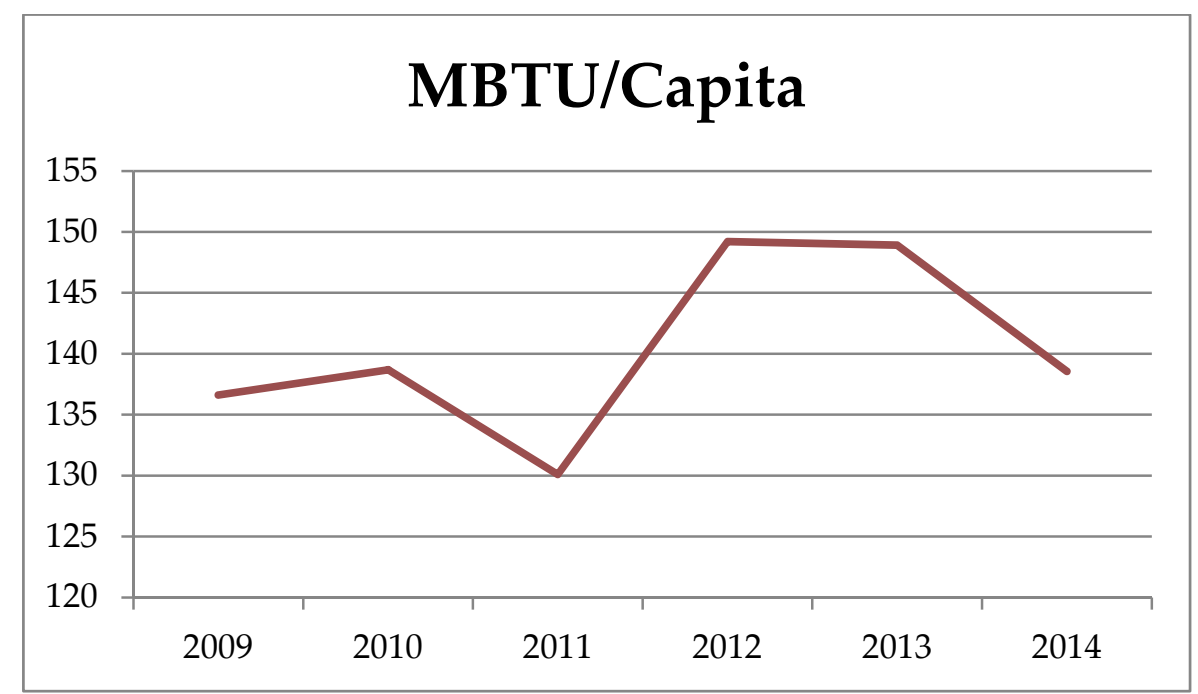

Figure 7. Site's Total Energy Use Divided by Total Operational Staff on Site (MBTU/capita)

\section{Projected Performance}

Approximately 50k gsf of facility construction is planned to be occupied between the beginning of FY 2015 through FY 2020. Much of this construction is the TRU Waste Facility Project. The reduction in space during that time period is planned to be about 420k gsf. Therefore, net footprint reduction will be about 370k gsf. Approximately 950k gsf is planned to be excessed between FY 2015 and FY 2020. Net energy reduction is estimated to be about 135,000 million BTU/yr.

Table 4 shows the Laboratory's actual and projected electricity consumption in the high-energy mission specific facilities (HEMSF).

Table 4. Actual and Projected Electricity Consumption and HEMSF/Demand Growth (MWh)

\begin{tabular}{|c|c|c|c|c|c|c|c|c|c|c|}
\hline & 2014 & 2015 & 2016 & 2017 & 2018 & 2019 & 2020 & 2021 & 2022 & 2023 \\
\hline $\begin{array}{l}\text { Total Electricity } \\
\text { Consumption }\end{array}$ & 396,079 & 496,960 & 541,603 & 565,153 & 563,002 & 583,135 & 700,107 & 713,679 & 741,302 & 752,542 \\
\hline DARHT & 5,658 & 5,580 & 5,580 & 5,580 & 5,580 & 5,580 & 5,580 & 5,580 & 5,580 & 5,580 \\
\hline
\end{tabular}




\begin{tabular}{|c|c|c|c|c|c|c|c|c|c|c|}
\hline NHMFL & 4,214 & 4,200 & 4,200 & 4,200 & 4,200 & 4,200 & 4,200 & 4,200 & 4,200 & 4,200 \\
\hline SCC & 67,512 & 103,284 & 135,197 & 127,153 & 127,153 & 138,506 & 188,217 & 162,726 & 162,726 & 171,808 \\
\hline CCF & 10,267 & 13,736 & 17,217 & 17,170 & 17,170 & 17,170 & 17,217 & 17,170 & 17,170 & 17,170 \\
\hline LDCC & 29,690 & 55,801 & 55,954 & 55,801 & 55,801 & 55,801 & 55,954 & 55,801 & 55,801 & 55,801 \\
\hline $\begin{array}{l}\text { SM-30 (this } \\
\text { location or } \\
\text { another) }\end{array}$ & 0 & 0 & 0 & 16,819 & 16,819 & 16,819 & 67,461 & 67,277 & 67,277 & 67,277 \\
\hline $\begin{array}{l}\text { TA53 (all } \\
\text { programs) }\end{array}$ & 81,932 & 107,946 & 107,811 & 125,864 & 125,864 & 137,132 & 155,960 & 197,864 & 227,864 & 232,364 \\
\hline RLUOB/CMRR & 9,668 & 10,424 & 16,801 & 16,383 & 16,759 & 16,759 & 16,759 & 16,759 & 16,759 & 16,759 \\
\hline TA-55 & 13,775 & 14,022 & 14,004 & 14,004 & 14,004 & 14,004 & 14,004 & 14,004 & 14,004 & 14,004 \\
\hline $\begin{array}{l}\text { All Other } \\
\text { Consumption }\end{array}$ & 169,363 & 181,967 & 184,839 & 182,179 & 179,653 & 177,164 & 174,756 & 172,299 & 169,922 & 167,579 \\
\hline \multicolumn{11}{|c|}{ Effect of Sustainability Investments in Conservation (MW-Hrs) } \\
\hline $\begin{array}{l}\text { Building } \\
\text { Automation } \\
\text { Upgrades }\end{array}$ & 1,100 & 1,100 & 2,200 & 3,300 & 4,400 & 5,500 & 6,600 & 7,700 & 8,800 & 9,900 \\
\hline $\begin{array}{l}\text { Building Re- } \\
\text { Commissioning }\end{array}$ & 2,900 & 1,200 & 2,400 & 3,600 & 4,800 & 6,000 & 7,200 & 8,400 & 9,600 & 10,800 \\
\hline $\begin{array}{l}\text { Server } \\
\text { Consolidation @ } \\
\text { CCF }\end{array}$ & 0 & 900 & 1,800 & 1,800 & 1,800 & 1,800 & 1,800 & 1,800 & 1,800 & 1,800 \\
\hline $\begin{array}{l}\text { Resulting } \\
\text { Electricity } \\
\text { Consumption }\end{array}$ & 396,079 & 493,760 & 535,203 & 556,453 & 552,002 & 569,835 & 684,507 & 695,779 & 721,102 & 730,042 \\
\hline
\end{tabular}

Through planned investments in FY 2015, LANL estimates that the site will reduce its energy intensity by 3\%. In FY 2015, LANL will invest \$1.8M in its facilities to conduct recommissioning activities in HPSB facilities and upgrade BASs in one large exhaust facility and the main campus library to enable night setbacks and repair HVAC systems. These two facilities were selected due to the potential impact on the energy intensity reduction target.

Funding projections are adjusted annually as part of the budget process. LANL modifies its site-wide Facility Disposition Plan to align with program funding expectations for disposition. The disposition plan includes funding source, planned excess year, estimated disposition year, amount of gsf, and related costs. Annual disposition plans are aligned with this Site Sustainability Plan, the Ten-Year Site Plan (TYSP), which includes new construction or lease plans, and the LRDP.

Integration of the Facility Disposition Plan with the Site Sustainability Plan goals assures that investments are not made for metering or for energy reduction projects in facilities that are planned for disposition. In addition, plans to meet the FY 2015 energy intensity goals must factor in the effect of the reduction of the total Laboratory footprint and projected energy reduction associated with facilities planned for disposition. 


\section{EISA SECTION 432 ENERGY AND WATER EVALUATIONS, BENCHMARKING, PROJECT IMPLEMENTATION, AND MEASURES FOLLOW-UP}

\section{Performance Status}

LANL has 84 covered facilities that receive energy and water audits to comply with benchmarking requirements. In FY 2014, LANL completed energy audits in 21 buildings or approximately 25\% of the covered facilities. LANL's EISA 07 facility evaluations are used to generate a list of energy and water conservation measures. All proposed measures are entered into a searchable "Energy Management Database," which was initially developed in 2012 and captures improvement measures at the building level. Energy and water conservation measures are categorized using a return on investment or simple payback calculation. Maintenance staff can use the list of measures for their annual maintenance planning and include any necessary maintenance in the deferred maintenance reports.

\section{Projected Performance}

LANL is scheduled to perform energy and water audits within approximately $25 \%$ of the covered facilities in FY 2015. LANL will complete energy and water assessments concurrently following the original HVAC schedule. The list of 84 facilities to be audited in FY 2015 is reported within the annual CEDR.

\section{INDIVIDUAL BUILDINGS OR PROCESSES METERING FOR 90\% OF ELECTRICITY (BY OCTOBER 1, 2012); FOR 90\% OF STEAM, NATURAL GAS, AND CHILLED WATER (BY OCTOBER 1, 2015)}

\section{Performance Status}

In FY 2011, LANL completed electric meter installations and achieved compliance with the electric meter goal and is metering over $90 \%$ of electric consumption on individual buildings and processes loads of the site's total electricity use. All electricity distributed throughout LANL is measured by 131 electric meters at the 13.2-kilovolt level in distribution switchgears. During year-end review the metered percentage of LANL's electric load dropped below the previous reported 90\% metered most likely due to an increase in nonmetered usage. In FY 2015, LANL will review non-metered facilities with regard to occupancy and process for future metering candidates where economically practicable.

LANL has 21 water meters that were previously read through a standalone Equipment Surveillance System (ESS). In FY 2015, these meter locations will be evaluated as possible candidates to tie into the same network data collection system as the electric meters. There were eight cooling towers and eight water tanks remotely monitored by the ESS. There are eight satellite steam plants and one individual building that have their water meters manually read and reported on a monthly basis. LANL will install individual building water meters per the recommendations of the recently revised FEMP guidance and where practicable.

Natural gas coming into LANL is metered at two main stations, Tech Meters 1 and 4 . There are 47 other gas meters/consumers that are read and usage reported. Of these 47 meters, 10 gas meters are interchange points between LANL and Los Alamos County. Steam is generated at the TA-3 Co-Generation Plant and is metered as it leaves the facility. During FY 2014, two individual building steam meters and five individual facility heating hot water meters were installed, and data have begun to be collected. Table 5 lists the Laboratory's metering goals, status, and planned actions. 
Table 5. Metering Goals, Status, and Planned Actions

\begin{tabular}{|c|c|c|}
\hline SSPP Metering Stretch Goals & FY 2014 Performance Status & Planned Actions and Key Issues \\
\hline $\begin{array}{l}\text { Install electricity meters on individual } \\
\text { buildings or processes at each site so } \\
\text { that these individually metered } \\
\text { buildings and processes account for at } \\
\text { least } 75 \% \text { of the site's total electricity } \\
\text { use by October } 1,2011 \text {, working } \\
\text { toward a goal of } 90 \% \text { by October } 1 \text {, } \\
2012 \text {. }\end{array}$ & $\begin{array}{l}\text { LANL achieved compliance with the } \\
\text { electric meter goal of metering } 90 \% \text { of } \\
\text { the sites' total electric load on an } \\
\text { individual building and process load } \\
\text { level by October } 1,2012 \text {. Recent data } \\
\text { have shown an increase in } \\
\text { consumption, which has reduced the } \\
\text { metered load to } 87.8 \% \text {. }\end{array}$ & $\begin{array}{l}\text { Non-metered facilities will be evaluated } \\
\text { for possible future electric meter } \\
\text { installations and installed where } \\
\text { practicable. }\end{array}$ \\
\hline $\begin{array}{l}\text { Install natural gas, steam, and chilled } \\
\text { water meters on individual buildings or } \\
\text { processes so that these individually } \\
\text { metered buildings and processes } \\
\text { account for at least } 10 \% \text { of the site's } \\
\text { natural gas, steam, and chilled water } \\
\text { use by October } 1,2011 \text { (10\% for each } \\
\text { utility) and } 90 \% \text { by October } 1,2015 \\
\text { ( } 90 \% \text { for each utility). }\end{array}$ & $\begin{array}{l}\text { In FY14, LANL focused metering } \\
\text { program efforts on upgrading the } \\
\text { server and software that supports the } \\
\text { metering platform. Data were also } \\
\text { collected and utilized for building } \\
\text { maintenance and energy reduction } \\
\text { efforts. }\end{array}$ & $\begin{array}{l}\text { LANL will continue to support and expand } \\
\text { the metering program to support the } \\
\text { sustainability goals. LANL will review new } \\
\text { FEMP metering guidance and update the } \\
\text { metering plan to meet new metering } \\
\text { goals. }\end{array}$ \\
\hline $\begin{array}{l}\text { Independently meter } 40 \% \text { of agency } \\
\text { data centers by October } 1,2011 \text {, } \\
\text { working toward a goal of } 100 \% \text { by } \\
\text { October } 1,2015 \text {. }\end{array}$ & $\begin{array}{l}\text { Currently, LANL has two of the three } \\
\text { major data centers sub-metered, } \\
\text { approximately } 66 \% \text { complete. }\end{array}$ & $\begin{array}{l}\text { LANL will continue to monitor the LDCC } \\
\text { and the SCC PUE data. LANL will } \\
\text { continue to monitor the overall energy use } \\
\text { in the CCF and evaluate upgrades to } \\
\text { include PUE monitoring. }\end{array}$ \\
\hline
\end{tabular}

\section{Projected Performance}

LANL has one remaining economically practicable thermal (steam) meter installation to complete. LANL has chilled water for comfort cooling in only two main facilities: TA-03-0207, LANL Research Library, and TA03-0132, Central Computing Facility, which also feeds several smaller building loads. These two locations receive chilled water from the TA-03-1498, Laboratory Data Communications Center (LDCC). LANL has determined that metering these facilities is not economically practicable and will re-evaluate meter installation activities after receiving new DOE metering guidance.

\section{COOL ROOFS, UNLESS UNECONOMICAL, FOR ROOF REPLACEMENTS UNLESS PROJECT ALREADY HAS CD-2 APPROVAL, NEW ROOFS MUST HAVE THERMAL RESISTANCE OF AT LEAST R-30}

\section{Performance Status}

NNSA's Roof Asset Management Program (RAMP) manages roofing assets across the DOE Complex. RAMP was established to help manage and preserve the roof systems that protect the critical assets in the NNSA inventory. All roofs replaced through RAMP are required to meet the Secretary's initiatives to reduce energy consumption with increased thermal requirements of R-30 insulation and "cool" roof membranes. Since 2006, a RAMP design criterion specifies that new roofs have a 20+ year life and meet a thermal resistance of R-30. RAMP designs have also permitted LANL to disallow the use of inferior roofing systems with short life spans. RAMP has been providing reflective light-colored or white surfaces on roof replacements since 2005.

While individual metering of energy costs at a building level have not been obtained, estimates using the EnergyWise energy savings calculator have established average cost reductions of over 69\% per year for all NNSA managed sites. At LANL, this equates to $\$ 143,500 /$ year and $\$ 2.8$ million over 20 -year roof life expectancy. The RAMP database ranks all facilities by age/remaining life and mission dependency. Facilities 
with poor or failed roofs have been upgraded to mission-dependent and mission-critical as the goals of LANL have changed, therefore allowing for roof replacement to meet new mission needs. When necessary, poor roofs of aging facilities are often repaired to extend the life of the roof to meet a future demolition date in lieu of a full replacement. Fiscally responsible management of the roof assets to ensure enduring operations until a facility is no longer needed.

In FY 2014, through RAMP, LANL repaired or replaced 41,705 sq. ft. of building roofs with better insulated roofs.

\section{Projected Performance}

Cool roofs are part of LANL's engineering standards and will continue to be implemented for most roof replacement projects. Every roof will be replaced within the parameters established at an R-value of 30 or above and the membranes will meet the cool roof initiatives.

In FY 2015, a total of eight facilities, or about 65,857 sq. ft., will receive a replacement of all roofs or portions of the roofs.

\section{$15 \%$ OF THE NUMBER OF EXISTING BUILDINGS GREATER THAN 5,000 GROSS SQUARE FEET (GSF) TO BE COMPLIANT WITH THE FIVE GUIDING PRINCIPLES OF HPSB BY FY 2015}

\section{Performance Status}

Executive Order 13514, Sec. 2(g) directs the head of each agency to "implement high performance sustainable Federal building design, construction, operation and management, maintenance, and deconstruction by ensuring that all new construction, major renovation, or repair and alteration of Federal buildings complies with the Guiding Principles for Federal Leadership in High Performance and Sustainable Buildings (Guiding Principles) and ensuring that at least 15\% of the agency's existing buildings (above 5,000 gross square feet) and building leases (above 5,000 gross square feet) meet the Guiding Principles by fiscal year 2015 and that the agency makes annual progress toward 100\% conformance with the Guiding Principles for its buildings inventory."

In response to these goals and guidance on implementing the Guiding Principles, LANL has selected 31 buildings (15\% of total number of buildings that are 5,000 square feet and above) and is working to implement the guiding principles within these facilities. LANL is currently reporting 73\% completion in the Environmental Protection Agency's (EPA's) Energy Star Portfolio Manager database. LANL plans to continue implementing the Guiding Principles within selected HPSBs focusing on HVAC and BAS recommissioning. LANL is investing approximately $\$ 1.3 \mathrm{M}$ in HPSBs in FY 2015 as part of the overall funding to reduce energy use in facilities. LANL will focus on high ROI energy reduction, such as recommissioning, in order to also make progress in energy intensity reduction.

LANL is comprised of many aging facilities, which is part of the historical charm, but also considered a maintenance and retrofit challenge. A Recommissioning Agent was hired in 2011, and an internal dedicated team was formed. The Recommissioning Team is comprised of skilled individuals selected from different Laboratory organizations and consists of system engineers, mechanical engineers, recommissioning/startup experts, building automation system/controls experts, HVAC technicians, and engineering students. In addition, in recognition of the positive impacts this program has on energy reduction, the Maintenance department dedicated two technicians to the team. The team was fully formed in 2013 . The team uses the following five main recommissioning strategies: 1 ) building automation system scheduling for occupied/unoccupied time periods, 2) building automation system control re-set (static pressure re-set, temperature re-set and chilled/hot water re-set), 3) mechanical/controls validation of valves and actuators, 4) validation of sensors (flow and pressure), and 5) validate or rewrite and verify sequences of operation. The team verifies energy savings by comparing facility energy use after recommissioning strategies are 
implemented to the previous year's energy use. The team has achieved over $50 \%$ energy savings in some facilities and has completed recommissioning activities in over 700,000 square feet of facility space.

LANL's HPSB Recommissioning Team reduced the Laboratory's electrical usage by over $700 \mathrm{MWh}$ in FY 2014, which represents a savings of over 1,658 tons CO2e GHG emissions. The two highest reductions for the HPSB Recommissioning Team were buildings TA-3-1410 at 34\% reduction and TA-3-1411 at 54\% reduction. Full recommissioning was completed in 10 buildings within the HPSB program in FY 2014. The program also established a Building Automation System (BAS) Operations Center in FY 2014, which assists in sustaining the energy savings measures by allowing closer monitoring of the systems. During the summer of 2014, the second annual Building Energy Challenge was organized. The goal of the challenge was to increase energy usage awareness and encourage positive tenant behavioral changes.

The HPSB Recommissioning Team has already shown energy savings in key facilities while improving tenant comfort, and Laboratory management is very supportive of this effort (Figure 8). LANL is no stranger to multidisciplinary research teams dedicated to a single mission. The dedicated multidisciplinary

Recommissioning Team has created several key recommissioning processes that work well in aging facilities to save energy and reduce greenhouse gas emissions. High facility energy use had become the norm, but this team stepped in and now works closely together and solves problems. The team collaborates with recommissioning experts from other national laboratories, participates in conference calls, and recently shared lessons learned and program successes at the annual American Society of Heating and AirConditioning Engineers High Performing Buildings conference. The significant improvements in HPSB facility energy use are detailed in Figures 9 and 10.

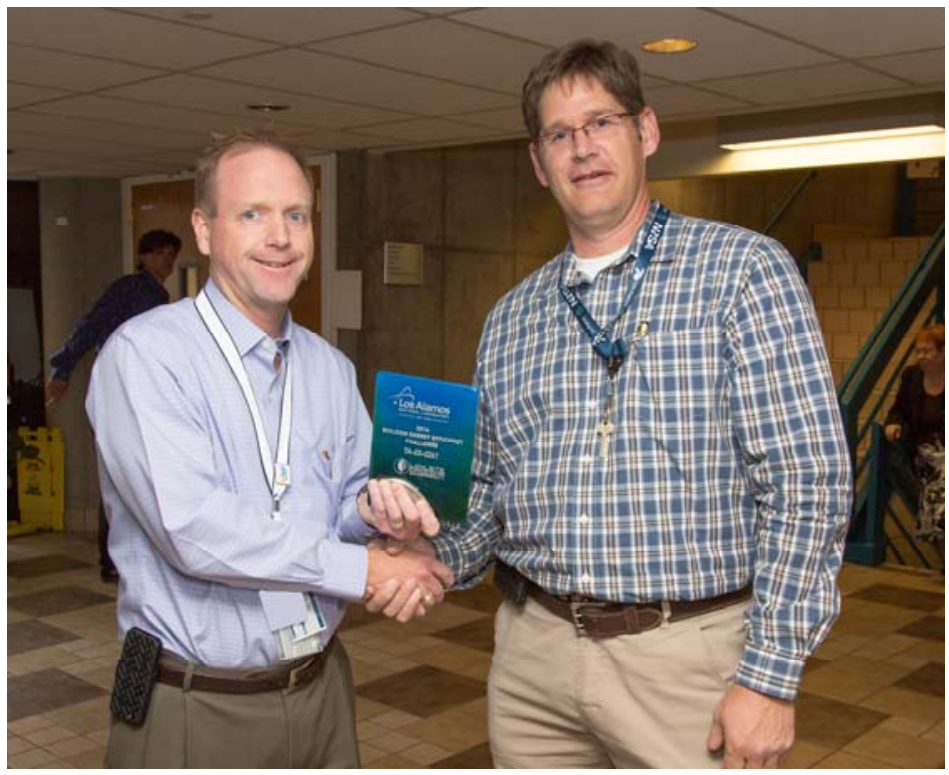

Figure 8. Carl Beard, former Principal Associate Director for Operations (left), presenting a 2014 Building Energy Efficiency Challenge trophy to Grant Stewart, Deputy Facilities Operations Director for Utilities and Institutional Facilities, for saving energy in the Otowi building. 


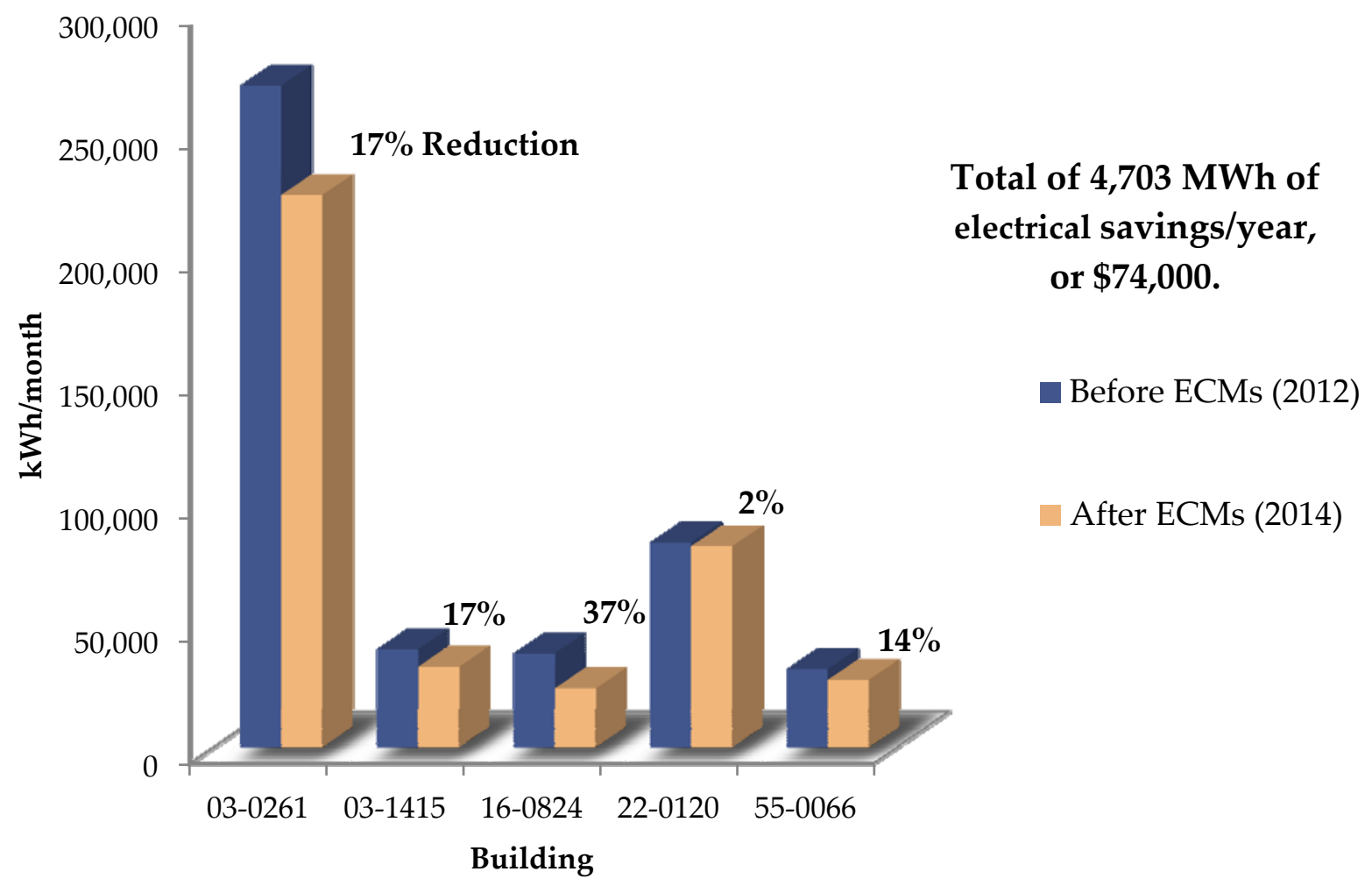

Figure 9. Monthly Energy Usage Reductions Achieved through Recommissioning

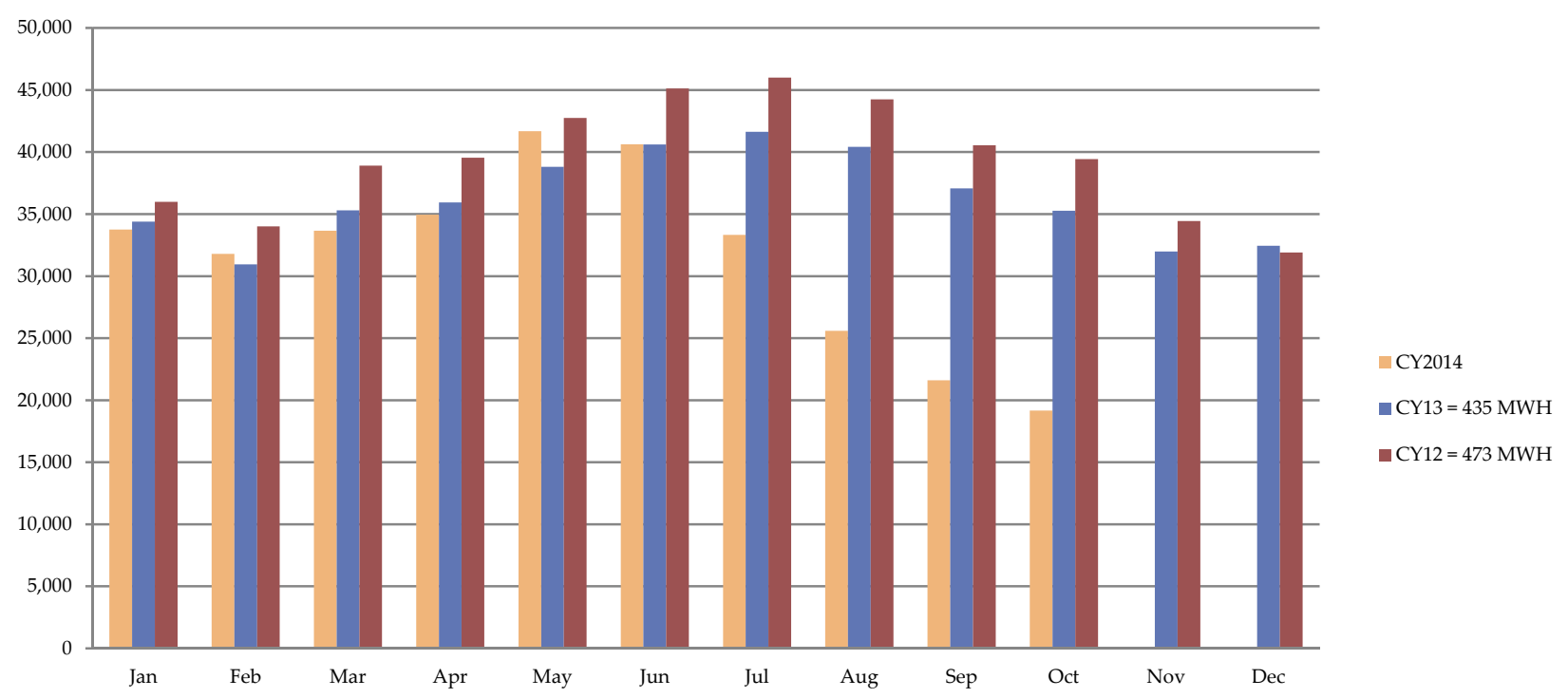

Figure 10. Monthly Energy Use Comparison for Building 03-1415 (MWh) 
In addition, the Institution's EMS EAP for FY 2015 will include HPSB elements. The directorates housed in buildings chosen for the HPSB program will be encouraged to include measurable goals within their EAPs to address tenant education and green purchasing. The HPSB program has integrated with the Laboratory's Long-Range Development Plan and the current leasing agreements in order to reach the goal target.

One of the initiatives LANL pursues is the establishment of building-level green teams, focusing on buildings that are part of the LANL HPSB program. The objective is integrating sustainability by discussing, planning, and executing sustainable practices in line with EMS objectives and targets and site sustainability goals on a building level. The goal is to improve integration and lines of communication between stakeholders, educate, inspire, and empower building occupants around sustainability, and create ownership in the effort to operate and maintain LANL buildings efficiently.

During FY 2014, LANL had four active green teams. LANL is using the green team approach to strengthen building-level stakeholder collaboration and communication. Building-level green teams help educate and incentivize building occupants to promote green practices. LANL Green teams are initiated through the EAP process because it indicates an Associate Directorate's commitment to promoting efficient use of resources, encouraging its staff to reducing waste, and promoting sustainable practices in the buildings they occupy. Building green teams are often composed of a champion (Associate Director), a senior management representative who acts as the green team lead, designated procurement representative, LANL HPSB team members, waste management coordinator, LANL energy manager, EMS/P2 team representative, building operations manager (Facility Operations Director [FOD]), building maintenance coordinator, WSST member, AD EMS point of contact (POC), division EMS POC, and tenant representative. To date, green teams have contributed to achieving LANL copy paper (containing at least 30\% post-consumer fiber) goals, energy conservation goals, sustainable acquisition goals, green janitorial cleaning product goals, and green furniture goals.

Table 6 identifies the time frame for completing recommissioning activities and remaining HPSB scope for full completion. 
Table 6. Remaining HPSB Scope

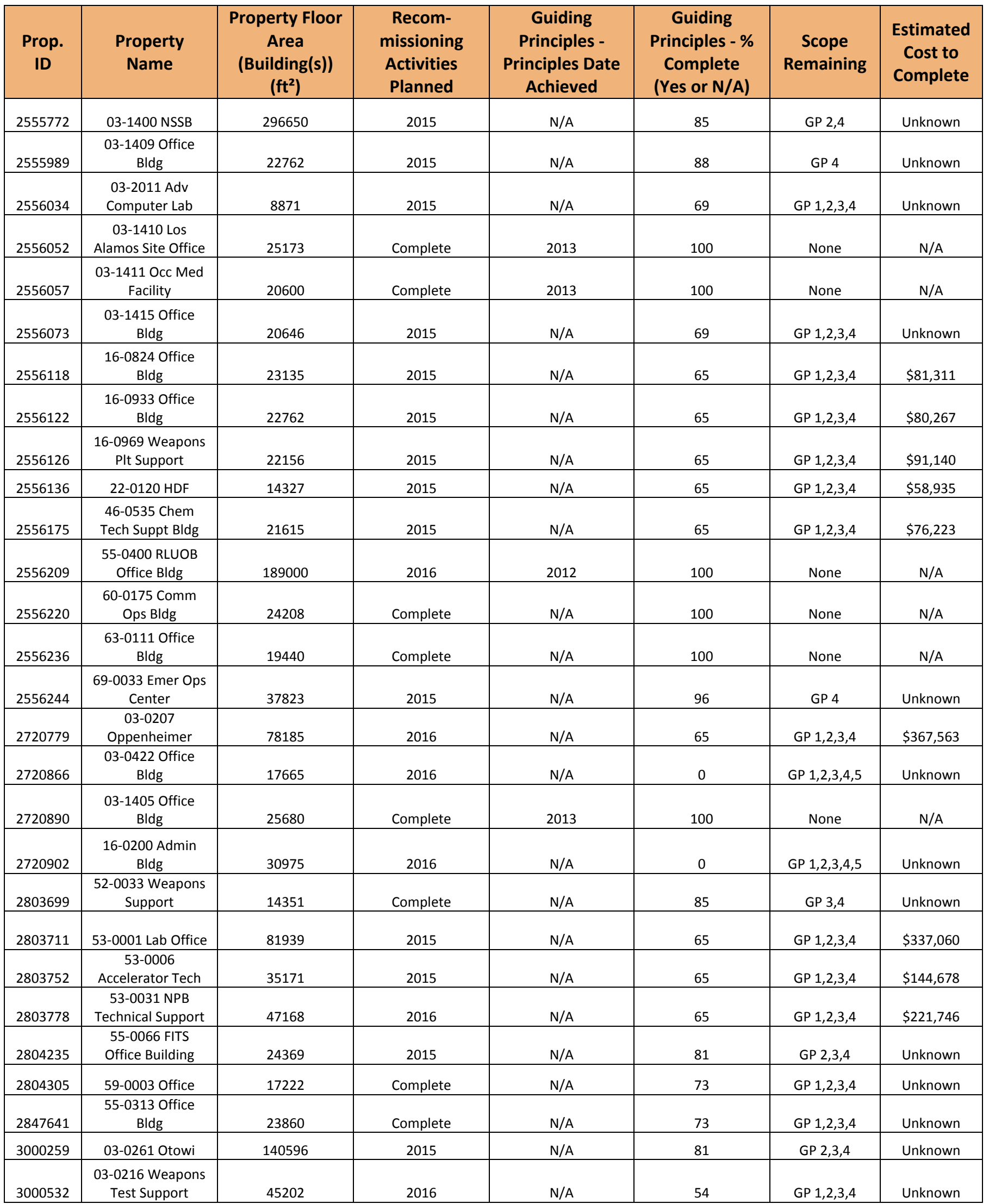




\section{Projected Performance}

In FY 2015, LANL plans to invest approximately \$1.3M in HPSB HVAC recommissioning and BAS controls tuning as part of the overall funding to reduce energy use in facilities. LANL will target energy reduction as the main HPSB focus in order to make progress in energy intensity reduction. LANL will complete HVAC recommissioning efforts in five facilities, which includes walk downs, BAS controls re-work, installing occupancy controls and water flow restrictors on faucets, and performing a test and balance of the air distribution after the BAS is optimized. LANL's Ten-Year Site Plan includes a list of sustainability projects highlighting HVAC improvements and recommissioning efforts in the HPSBs, lighting upgrades, implementation of energy conservation measures from the EISA 07 audits, and advanced utility metering. LANL is working to integrate sustainability with the project planning and increase the percentage of building's compliance with the HPSB Guiding Principles. LANL has completed the Guiding Principles in five facilities and does not plan on full completion of the HPSB Guiding Principles within any facilities in FY 2015 and will focus on recommissioning to get the highest ROI. LANL will meet the FY 2015 HPSB goal and has assigned this goal a "High" risk of non-attainment as it focuses investment on higher ROI projects.

\section{ALL NEW CONSTRUCTION, MAJOR RENOVATIONS, AND ALTERATIONS OF BUILDINGS GREATER THAN 5,000 GSF MUST COMPLY WITH THE GUIDING PRINCIPLES}

\section{Performance Status}

LEED Gold for new construction is included in LANL's Engineering Standards as of 2009.

Four buildings built between FY 2003 and FY 2006 were designed and constructed to LEED 1.0 standards. However, these four buildings were not registered or certified through the United States Green Building Council (USGBC). These buildings are the Defense Program's Nicholas C. Metropolis Center for Modeling and Simulation (otherwise known as the SCC); the National Security Sciences Building (NSSB); the Defense Nuclear Nonproliferation program's Nonproliferation and International Security Complex (NISC); and the Office of Science's Center for Integrated Nanotechnologies (CINT).

Since 2006, two additional buildings have been registered under the USGBC: the RLOUB and the Tactical Training Facility (TTF). The RLOUB has been completed and certified as LEED Gold. The TTF has been completed and is currently under review for LEED certification.

\section{Projected Performance}

LEED Gold and energy performance as standard design/construction requirements are being incorporated into early project design. Over 600,000 square feet of major new projects, currently in the early planning stages, are being formulated to be certified as LEED Gold projects. These facilities include the MaRIE Making, Measuring, and Modeling Materials (M4) Laboratory/Office building (100,000 sq. $\mathrm{ft}$.), the Global Security Laboratory/Training/Office building (170,000 sq. ft.), the CERDA Energetic Materials Laboratory/Office (40,000 sq. ft.), the TA-03 Fire Station (30,000 sq. $\mathrm{ft}$.), the TRU Waste Office (30,000 sq. ft.), and the Wellness Center Replacement (20,000 sq. ft.). Beginning in FY 2020, LANL will be investigating methods to achieve design of all new buildings as net-zero energy by FY 2030. Currently, under DOE directive, all new LEED construction is designed to meet a minimum improvement of $30 \%$ better than the American Society of Heating, Refrigeration, and Air-conditioning Engineers (ASHRAE) energy consumption baseline, where applicable. Some facilities, due to their experimental uses, are unable to meet the $30 \%$ energy-efficiency criterion because of the nature of their work activity requirements and must be considered on a case-bycase basis. 


\section{REGIONAL AND LOCAL PLANNING}

The Laboratory is situated on federally owned property located in Northern New Mexico within Los Alamos County and is currently operated by Los Alamos National Security (LANS) for DOE. The County was formed during World War II by the federal government as the site for Project Y of the Manhattan Project. Since that time, the Laboratory has been transformed through real property transfers to tribal, federal, local governments, and private landowners, resulting in the current LANL site area of approximately 36 square miles, which comprises a significant portion of the 109 square miles that Los Alamos County now encompasses. The County of Los Alamos governs the communities of Los Alamos and White Rock. The Laboratory's neighbors include among others the tribal governments of the Pueblo de San Ildefonso, Santa Clara Pueblo, Pueblo of Jemez, and Cochiti Pueblo. Other neighbors are Bandelier National Monument, administered by the National Park Service (NPS); and the Santa Fe National Forest, administered by the US Forest Service (USFS). Neighboring counties include Santa Fe, Sandoval, and Rio Arriba counties.

The Laboratory sponsors and engages interactive and ongoing relationships with all neighbors to promote common goals and interests, as well as resolving cross-jurisdictional issues. The Laboratory participates as a positive partner in many community efforts and, as a large stakeholder, has the ability to bring diverse entities together in a common effort.

The Laboratory maintains and allows use of a central transit station facility within TA-3 on DOE property. This central station allows three transit systems to converge at this point: the Laboratory taxi and bus system, the County of Los Alamos's Atomic City Transit, and the State of New Mexico's Department of Transportation Park and Ride, which contracts with All-Aboard America providing a regional bus service.

LANL and City of Santa Fe water managers work closely together to ensure that runoff from LANL into the Rio Grande does not adversely affect the Buckman Direct Diversion project, which takes surface water from the Rio Grande for use by the City and County of Santa Fe. LANL participates as a member of the East Jemez Resources Council, which also includes USFS, US Fish and Wildlife Service, NPS, Pueblo de San Ildefonso, New Mexico State Forestry Division, NMED, and New Mexico Department of Game and Fish. The Council has technical working groups that focus and report on resource-specific issues and efforts. LANL sponsors a Trails Working Group that coordinates trail management activities among interested stakeholders, including USFS, NPS, Pueblo de San Ildefonso, local residents, and Los Alamos County. LANL's Wildfire Management Program operates as part of the Southwest Coordinating Group, which collaboratively manages wildland fire and other incident management activities, and includes the USFS, USDI Bureau of Land Management, NPS, US Bureau of Indian Affairs, US Fish and Wildlife Service, the State of Arizona, and the State of New Mexico. LANL conducts periodic briefings and discussion sessions with members of the Four Accord Pueblos (Pueblo de San Ildefonso, Santa Clara Pueblo, Pueblo of Jemez, and Cochiti Pueblo), and has a Memorandum of Agreement with Pueblo de San Ildefonso for environmental sampling on their property. LANL is also participating in a Natural Resources Damage Assessment (NRDA) for the site. Trustee Council members for the NRDA include DOE, New Mexico State Office of the Natural Resource Trustee, Pueblo of Jemez, Santa Clara Pueblo, Pueblo de San Ildefonso, and USFS.

LANL is undertaking land management initiatives to mitigate risks on the site. LANL has an ongoing Wildfire Management Program to help prepare for and respond to wildland fires. LANL also recently completed a Forest Management Plan, which provides recommendations to address forest health and soil erosion risks in the face of a warming climate. LANL is currently developing a Boundary Protection Program, which would provide sediment filters and traps to reduce the transport of chemicals and radionuclides associated with sediments off LANL property. Finally, LANL is preparing a Stormwater Management Plan to address institutional stormwater quality and flooding issues. The plan will document a long-term strategy for improving water quality and stormwater hydrologic conditions. 


\section{GOAL 3: FLEET MANAGEMENT}

\section{$10 \%$ ANNUAL INCREASE IN FLEET ALTERNATIVE FUEL CONSUMPTION BY FY 2015 RELATIVE TO A FY 2005 BASELINE}

\section{Performance Status}

LANL has limited use of E-85 fuel in flex-fuel capable Protective Force (SOC) vehicles and in the Utility organization. Additionally, it has expanded the use of bio-diesel in its maintenance support vehicles. LANL subcontracts with a Northern New Mexico pueblo-owned business to provide bulk E-85 and bio-diesel fuel, which is transported to the site in a LANL mobile fuel tanker. In FY 2014, alternative fuel consumption was 86,753 gallons, of which 78,941 gallons was E-85 and 7,813 gallons was bio-diesel. Alternative fuel consumption in FY 2014 increased by approximately 31\% compared to the FY 2013 consumption (Figure 11).

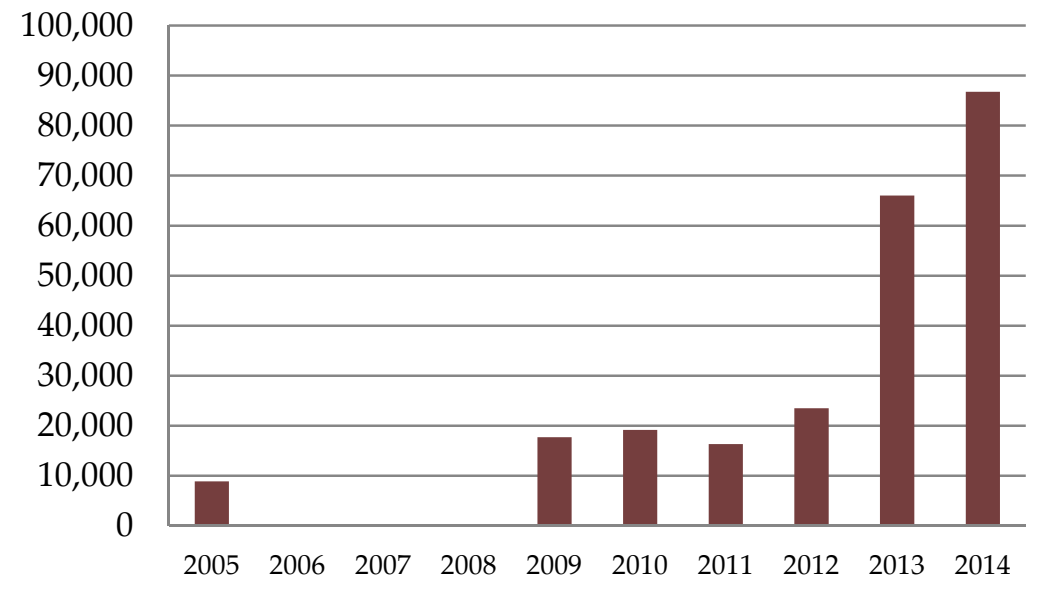

Fiscal Year

Figure 11. LANL Alternative Fuel Use (gallons)

\section{Projected Performance}

LANL will continue working toward increasing use of alternative fuel in the current fleet and will continue to use mobile fueling to provide alternative fuel.

\section{$2 \%$ ANNUAL REDUCTION IN FLEET PETROLEUM CONSUMPTION BY FY 2020 RELATIVE TO A FY 2005 BASELINE}

\section{Performance Status}

LANL decreased its fleet petroleum use in FY 2014 by $0.05 \%$ compared to FY 2013 usage (Figure 12). However, LANL has reduced fleet petroleum use by 21\% compared to a FY 2005 baseline. In FY 2014, LANL acquired 63 additional low GHG vehicles and increased its sedans by 19. The increase of sedans is the result of LANL's continuing effort to right-size its fleet and reduce overall fleet costs. Additionally, during the FY 2014 replacement cycle, LANL downsized 30 vehicles to smaller more fuel-efficient vehicles. 


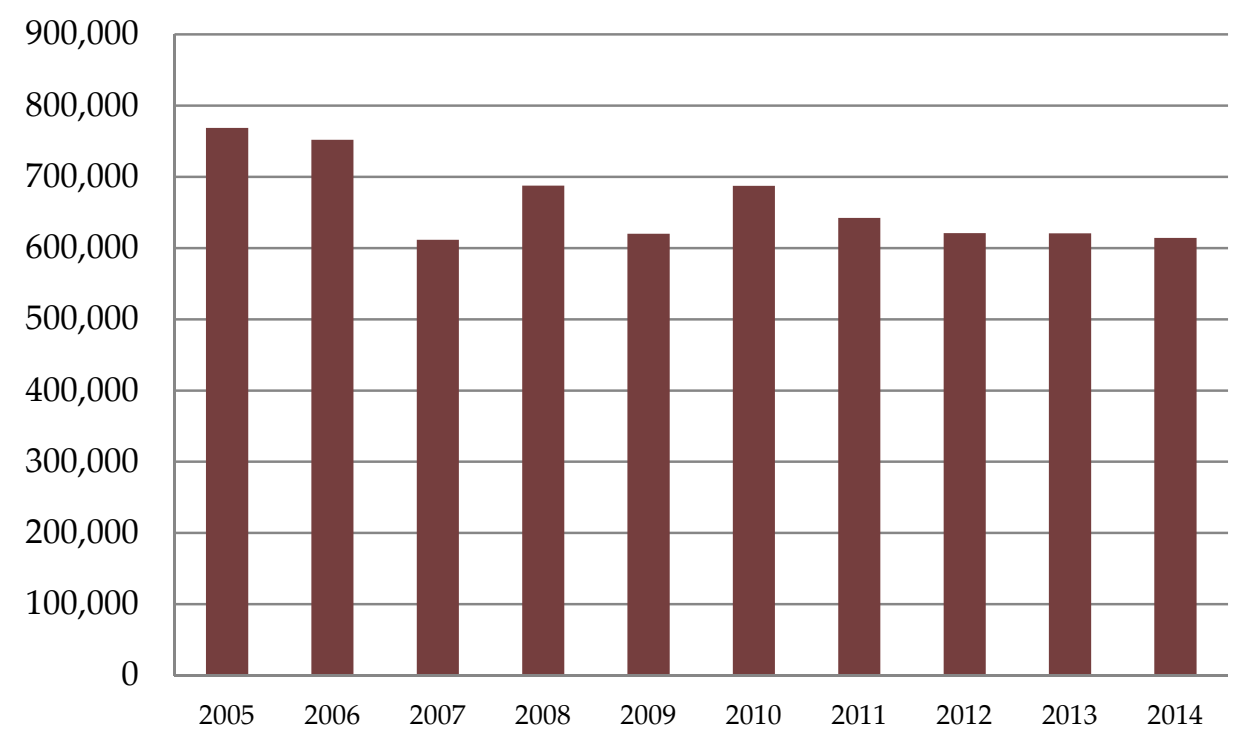

Fiscal Year

Figure 12. LANL Petroleum Fuel Use (gallons)

\section{Projected Performance}

LANL continues to research and test AFVs, including plug-in hybrids and electric cars as available. LANL continues to collect data on E-85 and hybrid vehicles and is working with management to downsize and right-size the Laboratory's fleet. During the FY 2015 annual replacement cycle, LANL will order more fuelefficient vehicles and low-GHG emitting vehicles where practical to meet the fleet sustainability goals. In FY 2013, LANL acquired two Chevrolet Electric Volts to pilot for further deployment across the Laboratory. These organizations have expressed an interest in supporting and promoting alternative vehicle use at the Lab and will provide customer feedback as to what their experience has been using this technology. More support is needed from GSA to reduce up front incremental costs for plug-in hybrid vehicles to encourage sites to adopt this technology.

\section{$100 \%$ OF LIGHT DUTY VEHICLE PURCHASES MUST CONSIST OF AFVS BY FY 2015 AND THEREAFTER (75\% FY 2000-FY 2015)}

\section{Performance Status}

LANL's total fleet consists of 1,546 vehicles, of which 772 or $49 \%$ of those are considered Light Duty Vehicles (LDVs). Of the 772 LDVs, 549 or $71 \%$ are AFVs. Vehicles that weigh less than 8,500 lbs gross vehicle weight rating (GVWR) are considered LDVs. EPAct 2005 requirements apply to fleets of 20 or more LDVs that are centrally fueled or "capable of being centrally fueled" and are primarily operated in a MSA/Consolidated Metropolitan Statistical Area (CMSA). Vehicles heavier than 8,500 lbs GVWR or not located or operated primarily in an MSA or CMSA are exempt from the requirements. Since Los Alamos is not located in an MSA, we are exempt from this requirement, however, in support of the requirements, 71\% of LANL's current LDVs are alternative fuel vehicles.

\section{Projected Performance}

LANL will continue to increase the number of AFVs in its light duty fleet during each annual vehicle replacement cycle. 


\section{REDUCE FLEET INVENTORY ON NON-MISSION CRITICAL VEHICLES BY 35\% BY FY 2013 RELATIVE TO A FY 2005 BASELINE}

\section{Performance Status}

In support of the DOE Secretary's 35\% reduction plan, LANL has been contributing to NNSA's right-sizing collective effort of the fleet by reducing the number of vehicles that are no longer needed or are underutilized. LANL contributed to this initiative by reviewing and re-categorizing its vehicles into two categories: Mission Support and Mission Essential. As part of this year's annual GSA re-order process, vehicles not meeting NNSA's utilization standards, averaged over the last 24 months, will not be re-ordered. LANL continues to turn in vehicles that are no longer needed to meet the Laboratory's programmatic mission and turn in vehicles that have continually been underutilized.

\section{Projected Performance}

LANL will continue to support NNSA's reduction goal of 35\% by ensuring its fleet objectives are working towards the collective NNSA fleet management goal to right-size the composition of its fleet with its mission.

\section{GOAL 4: WATER USE EFFICIENCY AND MANAGEMENT}

$26 \%$ WATER INTENSITY (GAL./GSF) REDUCTION BY FY 2020 FROM A FY 2007 BASELINE

\section{Performance Status}

In FY 2014, LANL's water use reduction was heavily influenced by SERF operations and industrial water reuse at the SCC. LANL's total water use in FY 2013 was approximately 307 million gallons. About $25 \%$ of that total was used by the SCC, LDCC, and LANSCE cooling towers. Water intensity (gallons/sq. ft.) has decreased by approximately 3.5\% compared to the FY 2007 baseline. LANL water use was reduced by over 26\% in FY 2014 compared to FY 2013.

LANL's total water consumption for FY 2007 (about 335 million gallons), the baseline year used to calculate the water intensity, was the second lowest within the last 10 years. The average total water consumption for FY 2007 to FY 2013 is approximately 389 million gallons (Figures 13-15). In addition, LANL's footprint reduction efforts project an 835,000 sq. ft. reduction between FY 2007 and FY 2015. Due to the expected water use increase and increased water use to meet cooling demands, reaching the FY 2020 water intensity goal will be uneconomical for LANL. 


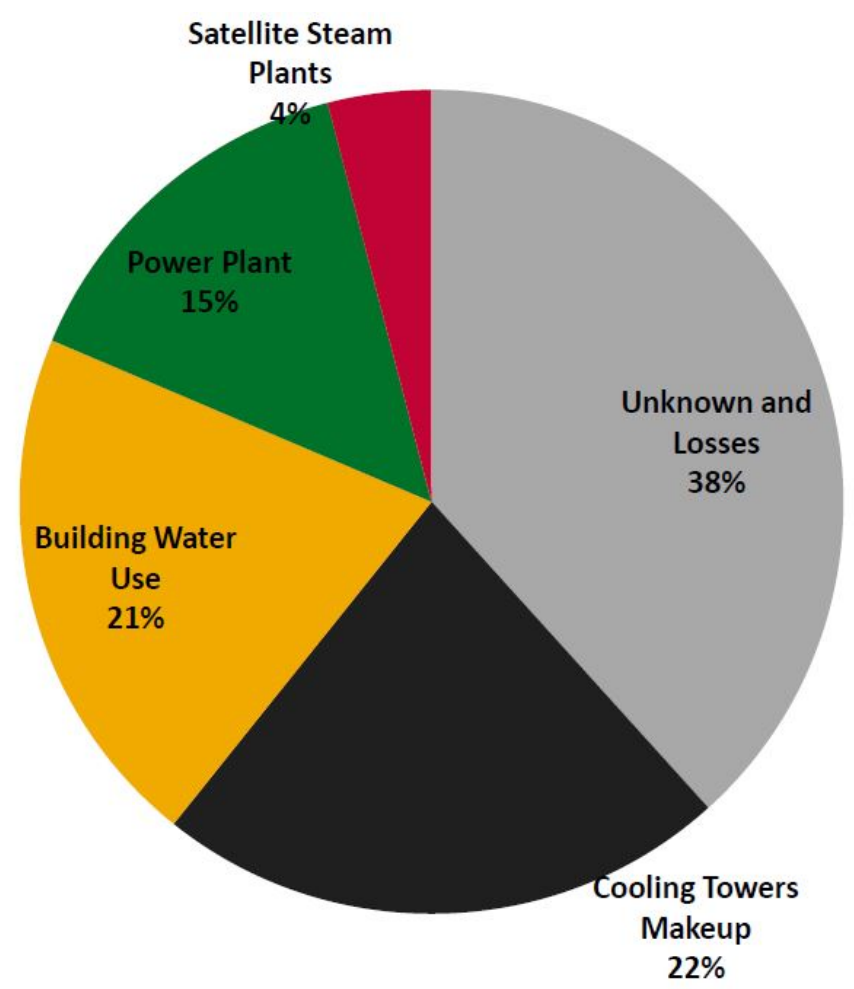

Figure 13. FY 2014 LANL Water Balance Prepared by PNNL during Water Assessment

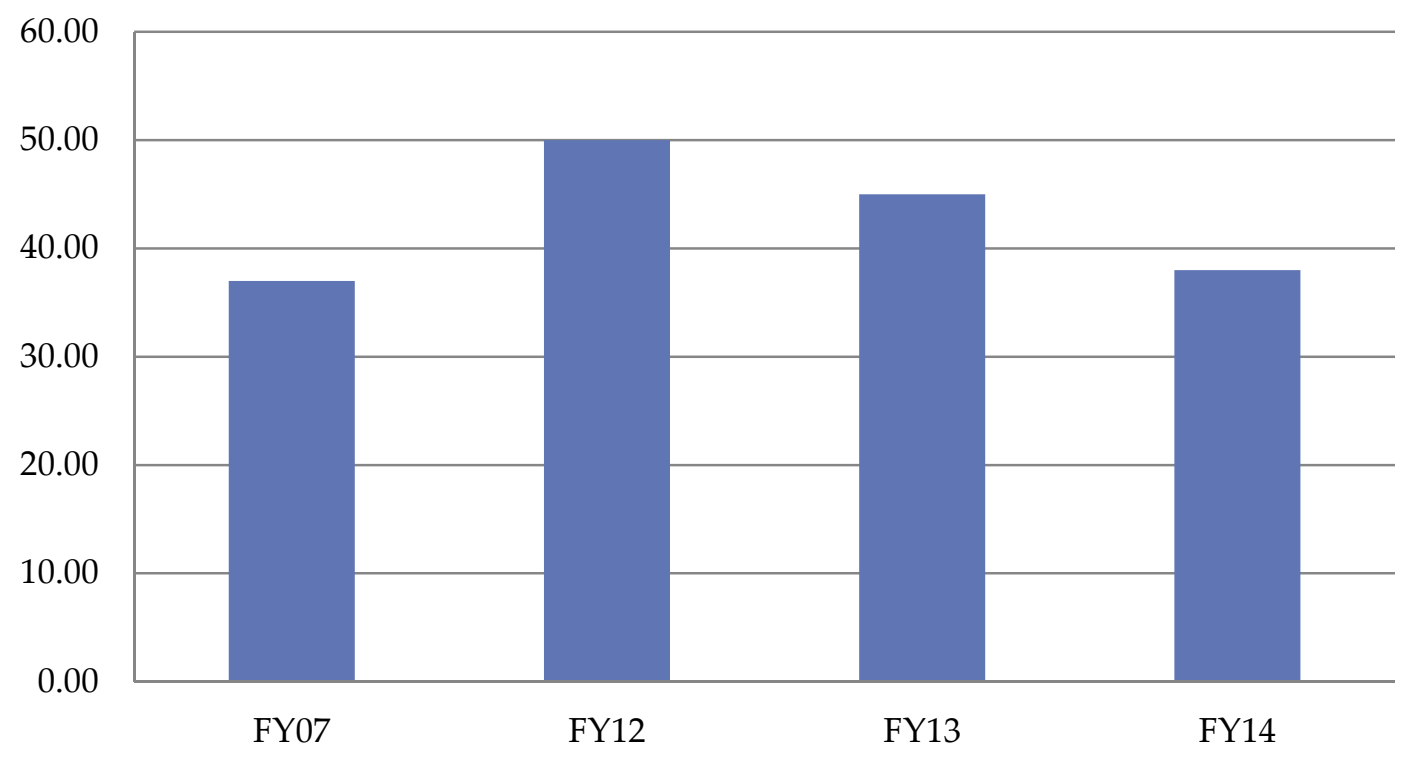

Figure 14. Total Water Use Intensity (gallons/sq. ft.) 


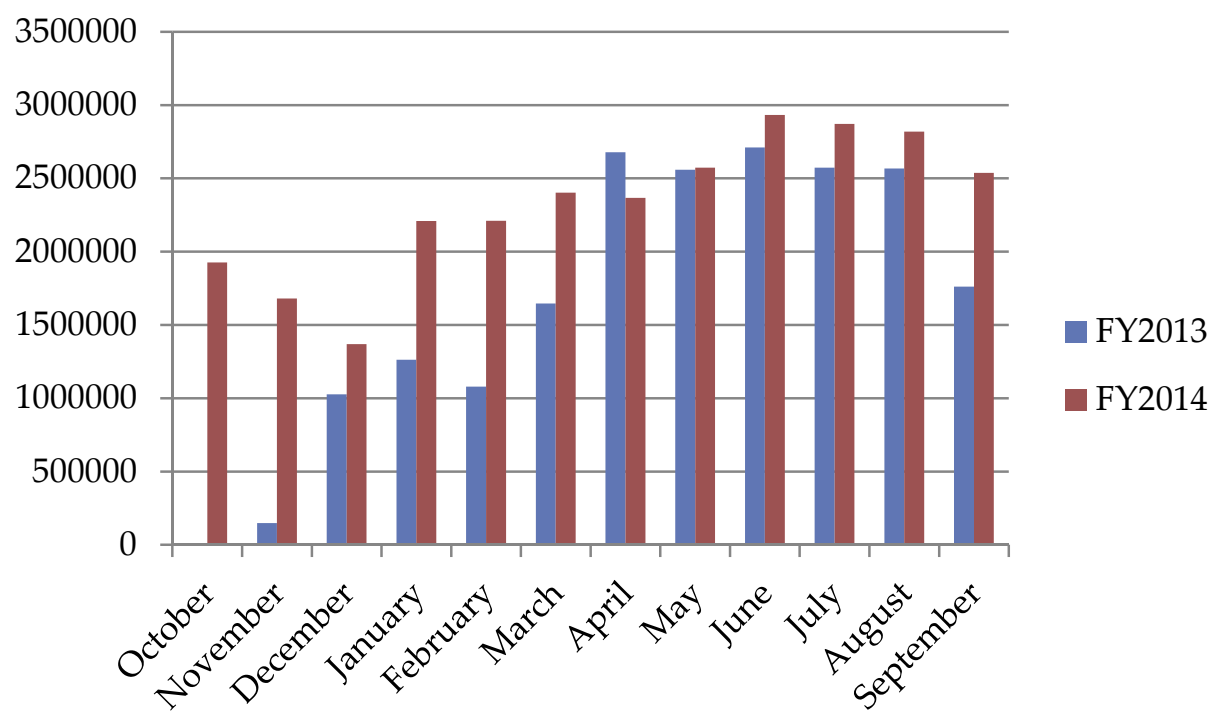

Figure 15. Monthly SERF to SCC Total Water Use (gal.)

LANL water usage represents approximately one-third of the total water usage from the regional aquifer. The 2008 Site-wide Environmental Impact Statement (SWEIS) measures potential environmental impacts by comparing projections of utility resource requirements against utility system capacities. LANL's annual water use ceiling, the system capacity, is 542 million gallons. Any water use exceeding this ceiling can be considered an indicator of an environmental impact, and further analysis is warranted. Water use below this ceiling is not expected to have any additional impacts to the regional aquifer. In addition, as projected in the 2008 SWEIS, trends in water levels in wells reflect a plateau-wide decline in regional aquifer water levels starting in 1977 in response to municipal water production, typically by several feet each year. No unexplained changes in patterns have occurred since this time. The decline is gradual and does not exceed one to two feet per year for most production wells. In areas where pumping has been reduced, water levels show some recovery. When pumping stops, the static water level returns in about six to 12 months. Hence, the water level trends suggest no adverse impacts on long-term water supply production from groundwater withdrawals (LANL 1998, LANL 2003).

\section{Projected Performance}

Due to the low environmental impact from LANL's current water level usage, LANL's overall sustainability efforts focus mainly on a cost-effective life-cycle approach emphasizing energy efficiency to reduce LANL's regional impact on water use associated with energy generation. In FY 2014, the Site Sustainability Program was funded at a level of $\$ 3.5 \mathrm{M}$ by the Director through indirect funding. Approximately $\$ 200,000$ of the $\$ 3.5 \mathrm{M}$ was allocated for cooling tower upgrades. Additionally, the Laboratory is investing \$3.2M per year of indirect funding in the operation of SERF to achieve its water reductions. Figure 16 shows the Laboratory's projected water consumption compared to the NNSA goal through FY 2023. Water use is expected to rise in FY 2018 due to increased use of cooling towers to support site and mission operations.

Although there is no expectation of supply shortfall nor of substantive environmental degradation from continued usage at present levels, LANL is implementing a project to reduce potable water use in selected cooling processes and in the steam generation equipment. In addition, LANL has collected water conservation measures from water assessments in over 80 facilities. Extrapolating from the audits completed to date, 8 million gallons per year could be saved if all LANL facilities were upgraded. This amounts to $2 \%$ of the average yearly water consumption over the last 10 years. Unfortunately, due to the low cost of water, the payback period is over 100 years. In light of this ROI, LANL has adopted an incremental approach to upgrade plumbing fixtures as they fail. LANL is making smart investments in water 
conservation measures that have a cost-effective life cycle (e.g., SERF and select cooling tower upgrades), and with a primary focus on high ROI energy efficiency measures, in order to reduce LANL's regional impact on water use associated with energy generation.

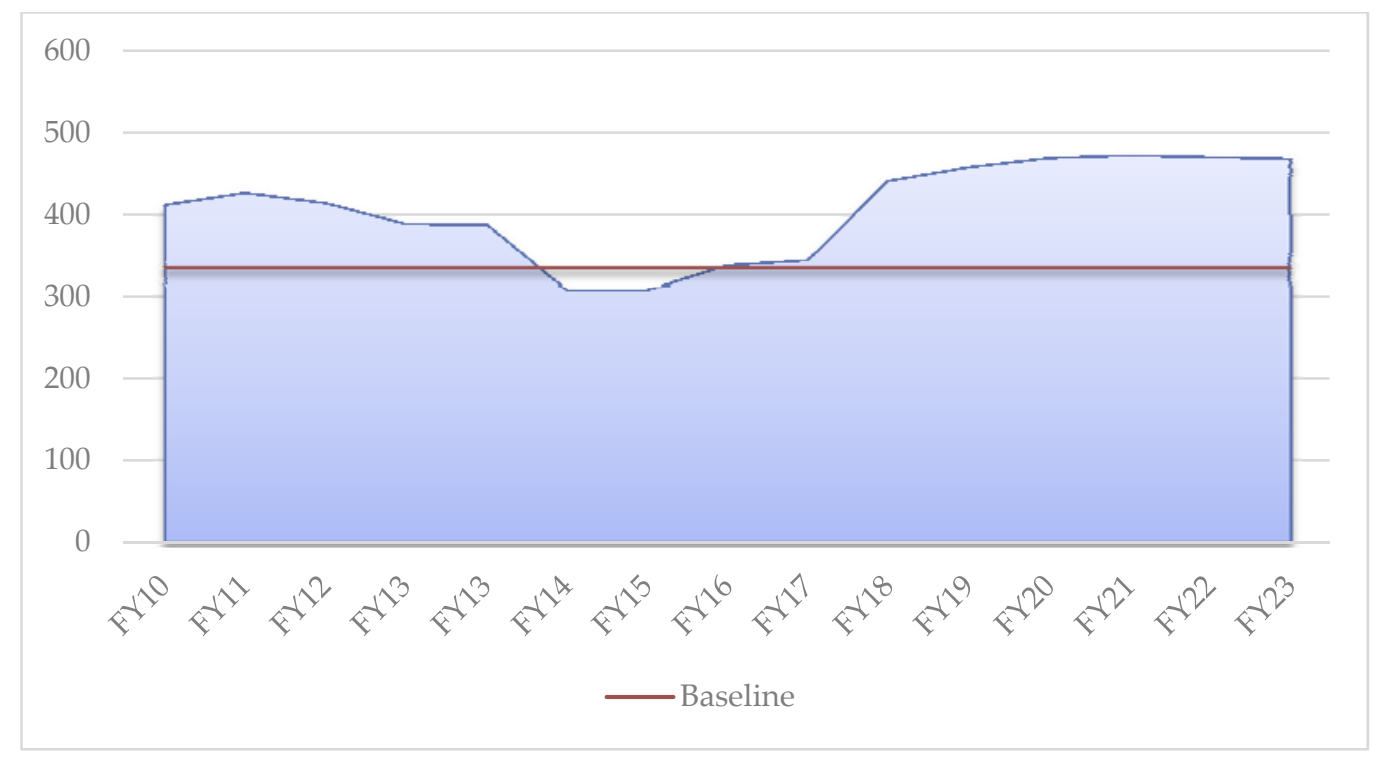

Figure 16. Water Use (Mgal) and Forecast

In addition to energy conservation measures that address regional water use, LANL will focus on the projects listed below to further reduce water consumption.

- In FY 2014, LANL started a construction project to install a new water chemical treatment system for the cooling towers at TA-55 that will provide real-time monitoring of the system and use a silica inhibitor to aide in the increase of cycles of concentration. Construction is scheduled for completion in calendar year 2014.

- SERF can produce up to $110,000 \mathrm{kgal} / \mathrm{yr}$ of reclaimed industrial water and is connected to the SCC cooling towers and the TA-3 steam plant. In FY 2014, SERF met all of SCC water needs. It is forecasted that the SCC will not consume all of SERF's capacity until 2018.

- LANL conducts a leak detection survey every two years and is scheduled for a survey in 2015. The identified water system leaks are prioritized with all other water system maintenance for repair. LANL will continue to maintain the distribution system by replacing portions of the more than 60year-old system as leaks are identified.

- Fifty monitored water meters have been installed. Many of these meters measure large consumers such as the TA-3 Co-Generation Plant processes, cooling towers, satellite steam plants, and water distribution flows. Data are being accumulated to establish a basis for conserving water.

- Water savings fixtures are being installed in HPSBs to align with the recommissioning schedule, as economically practicable.

- Domestic plumbing fixtures are being upgraded to modern water-conserving fixtures as fixtures fail.

- Many of the water-cooled cooling towers will be replaced due to age of the system. As the systems are funded for replacement, system engineers will evaluate options for water-conserving air-cooled systems. 
- In FY 2011, Pacific Northwest National Laboratory (PNNL) evaluated water usage and identified water saving opportunities across LANL. The report highlighted potential water conservation measures and their associated water, energy, and cost savings. One of the report findings identified approximately $23 \%$ of site consumption as "unknown." As a result, LANL metered a section of main water piping to determine the leak rate. The leak rate was relatively small $(\sim 5 \%)$ compared to industry average. LANL will continue investigations to determine the supply and discharge from main water users on site.

- In FY 2014, PNNL evaluated water usage at the Laboratory and found no significant water reporting errors and the "unknown" water use remains unknown. LANL is working with PNNL to develop an economical metering strategy and is planning to proceed with low-cost insertion type zone water meters with battery-powered data loggers to help identify the "unknown" water use.

$20 \%$ WATER CONSUMPTION REDUCTION OF INDUSTRIAL, LANDSCAPING, AND AGRICULTURAL (ILA) WATER BY FY 2020 FROM A FY 2010 BASELINE

\section{Performance Status}

All of LANL's water use is potable water and is, therefore, considered part of the $26 \%$ water intensity reduction goal reporting.

\section{Projected Performance}

LANL does not report on the ILA goal.

\section{GOAL 5: POLLUTION PREVENTION}

\section{RECYCLING \& WASTE DIVERSION (50\% BY FY 2015)}

\section{Performance Status}

The LANL Pollution Prevention (P2) program conducts pollution prevention projects, prepares the Hazardous Waste Minimization Report in compliance with the NMED Hazardous Facility Operating Permit, completes P2 regulatory compliance and DOE Sustainability Goal reporting in the SSP, holds the annual LANL P2 Projects awards competition, submits LANL P2 awardees for National P2 Awards, and directly funds generators to conduct P2 projects via the P2 Project Fund.

LANL has a large inventory of clean metals encumbered under the 2000 DOE Secretarial Moratorium and Suspension on recycling metals once located in a radiological area. In order to develop the processes and procedures to recycle such metals should the moratorium be lifted, LANL executed a pilot project in 20132014 using metals unencumbered by the moratorium. Following the development of new radiological survey and safety procedures, the 95-ton Energetic Pion Channel and Spectrometer (EPICS) at the Los Alamos Neutron Science Center was dismantled and surveyed to demonstrate that the metal is indistinguishable from background radiation. To further demonstrate hoisting, rigging, and transportation processes, several large cryogenic tank systems and obsolete storage tanks were also shipped for recycling in 2014. The first 40 tons of unencumbered, clean materials were shipped out in August and September 2014. Large-scale recycling of unencumbered metals will continue in 2015 and pave the way for the recycling of thousands of tons of additional materials should the moratorium be lifted. The photo on the left in Figure 17 shows the EPICS system in Area A, which was occupying valuable research space, and the photo on the right shows the EPICS system dismantled as of July 2014. 

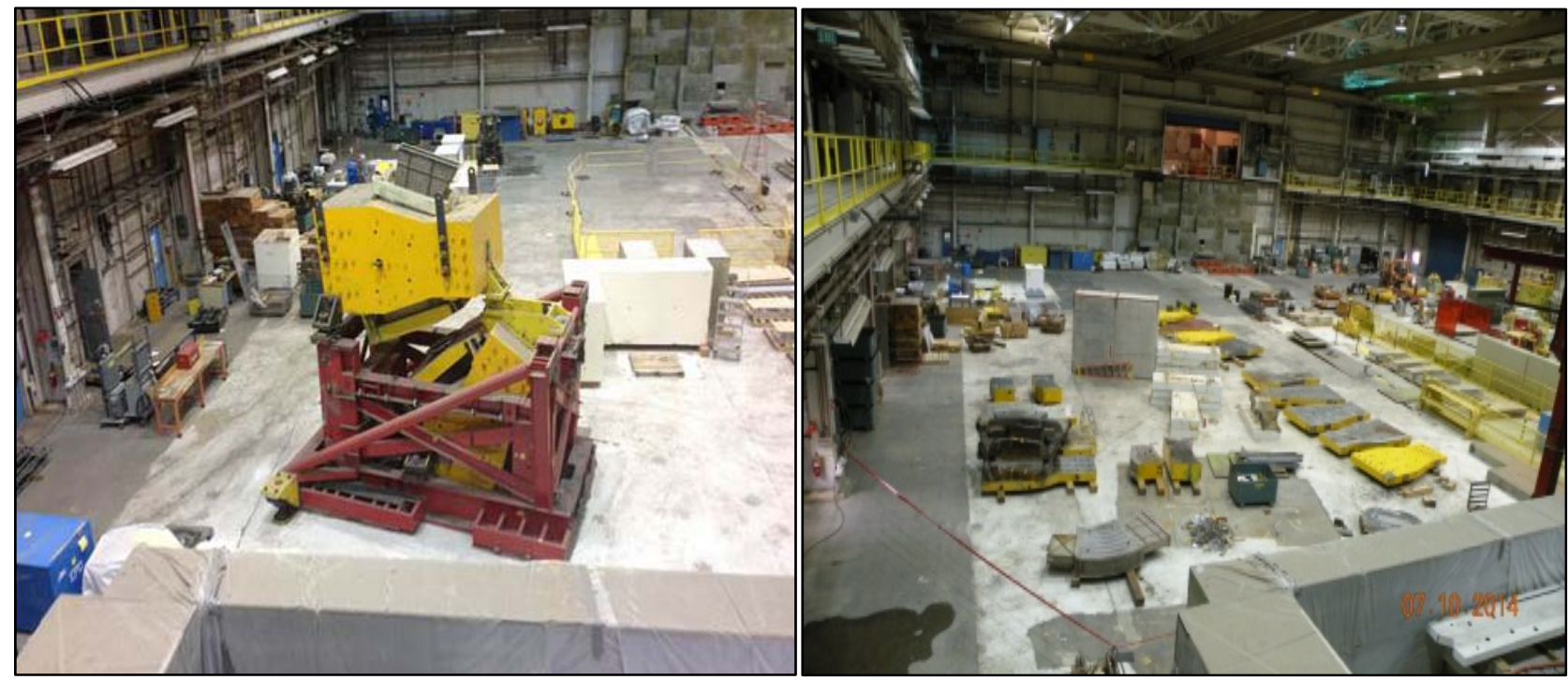

Figure 17. (Right) Area A EPICS System; (Left) EPICS System dismantled in July 2014

\section{Solid Non-Hazardous And Construction/Demolition Waste Diversion}

LANL diverted 55\% of solid, non-hazardous waste and $92 \%$ of construction and demolition waste in FY 2014. Additionally, LANL construction and demolition activities continued to produce clean fill for reuse on site; however, those numbers were not developed in time for the completion of this report. LANL's progress toward waste diversion goals, and overall recycling rates, is shown in Figure 18.

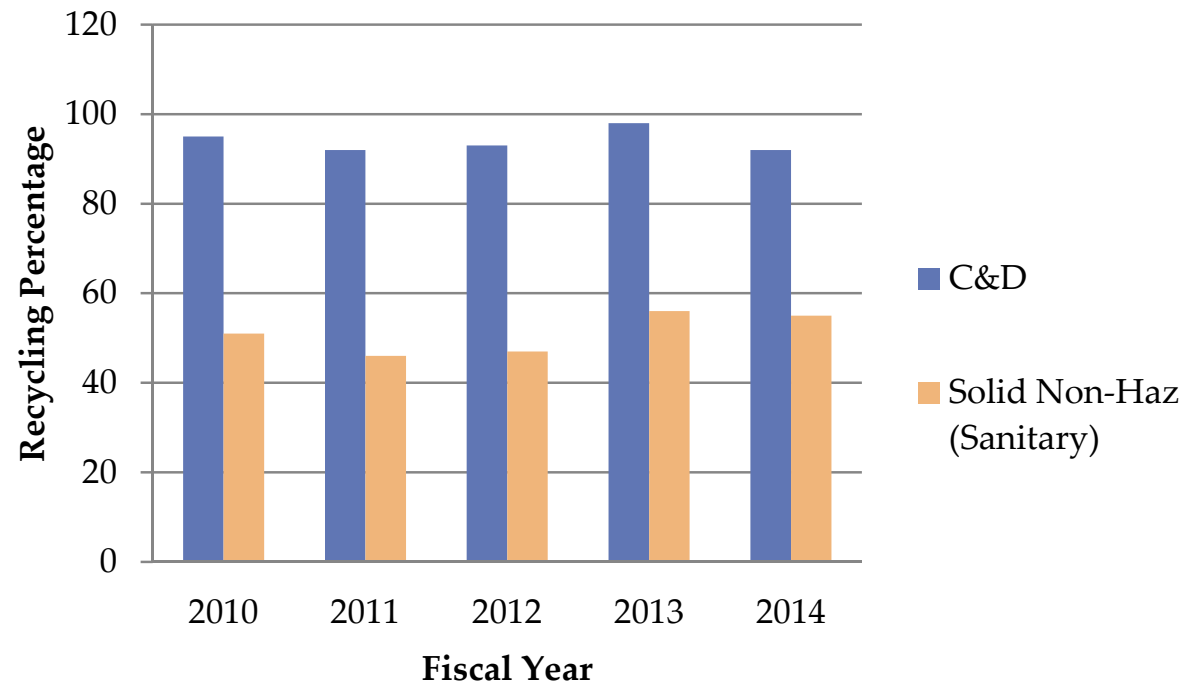

Figure 18. Progress towards Waste Diversion Goals

\section{LANL P2 Awards}

The FY 2014 LANL Annual Pollution Prevention Award Ceremony recognized 28 projects. The projects were completed during FY 2013 and involved more than 200 individuals from across numerous Laboratory organizations. The projects realized a conservatively estimated cost savings of over $\$ 10 \mathrm{M}$. Selected projects recognized at the FY 2014 LANL Pollution Prevention Award Ceremony were nominated for National Pollution Prevention Awards. 


\section{National Pollution Prevention Awards}

LANL received five NNSA National Pollution Prevention Awards during FY 2014, including one Best-in-Class award, and four Environmental Stewardship awards. (Note: The NNSA and DOE Pollution Prevention Awards are given to the previous fiscal year's projects.)

\section{Pollution Prevention Projects/Activities}

In FY 2014, LANL successfully completed 15 pollution prevention projects. The following are brief examples:

- Electronics Roundup $(\$ 30,000)$ : At multiple locations across the Laboratory, old and unwanted electronics were removed from RCAs. Approximately $35 \mathrm{~m}^{3}$ of electronics were collected and disposed as mixed low-level waste (MLLW). The expectation is that this equipment will not be replaced inside the RCAs, or replacement equipment will be smaller so that much less MLLW will be created by old electronics in the future.

- Installation of Covers on Metal Recycling Bins $(\$ 100,000)$ : Storage of metal for recycling presents a number of challenges, one of which involves preventing water (rain/snow) from collecting in the bins. Water collected in this manner must be sampled/analyzed and managed appropriately. Durable bin covers were purchased and installed on all of the metal recycling bins to prevent water collection, and thus eliminate the possibility that a New Mexico Special waste stream could be created inadvertently during storage.

- Replacement of Large Capacity Nitrogen System (\$230,000): An outdated, large capacity nitrogen storage tank and delivery system that was responsible for close to $60 \%$ resource loss due to leakage was replaced. The new tank and jacketed delivery system not only eliminated the loss of resource, but also reduced maintenance and delivery costs by two-thirds. All of the old tank and piping system was recycled.

- Re-purposed Building for Equipment Storage/MSGP No Exposure (25,000): A machinery/equipment storage pad, subject to sampling requirements in accordance with the MSGP, was removed from service after an adjacent building was identified as being a suitable candidate for use as storage. The building was refurbished to meet applicable requirements based on the new use of the building.

- HS-Pu Filtrate Vessel Design \& Replacement $(\$ 20,000)$ : Process operators were able to significantly reduce TRU waste by designing and implementing a new vessel for the filtrate recovery process. This new vessel has a much longer life span for usage, which will eliminate 5 drums of contaminated plastics generated annually $\left(\sim 1 \mathrm{~m}^{3}\right)$.

- Replacement of Oil-containing pumps with Oil-free scroll pumps in Radiological Operations $(\$ 40,000)$ : The application of oil-free pumps for use in radiological operations is an opportunity to eliminate significant sources of MLLW. Each pump contributes between five and 10 gallons of contaminated waste oil annually, so the replacement of six pumps eliminates between 30 and 60 gallons of MLLW.

- Smoke Alarm Recycling $(\$ 18,200)$ : The funds for this project will be used to recycle smoke detectors that contain americium and/or radium. These are smoke detectors that cannot be returned to their manufacturers and would otherwise be handled as MLLW.

\section{Unrestricted Materials Release}

The LANL procedure P412, Environmental Radiation Protection, describes the process and associated requirements for releasing materials from radiological areas. In 2014, two projects were funded by P2 to continue the progress towards radiological assessment capabilities for items/material directly impacted by the DOE moratorium on releasing suspect material to the public. This includes items/material that could be volumetrically contaminated (activated) and/or exhibit low levels of surface contamination potential. Procedures were developed and approved internally with the intent to demonstrate capabilities in FY 2014. A third-party verification audit was conducted on the process in late October 2014, with final results 
pending. LANL has identified four project efforts, affecting between 300 and 400 tons of potentially impacted metal, for execution in FY 2015 pending the outcome of the audit results.

\section{Integration of Pest and Landscape Management Practices}

Pesticide management activities in FY 2014 included the implementation of a Pesticide Discharge Management Plan (PDMP) by LANL in order to comply with changes in EPA's National Pollutant Discharge Elimination System (NPDES) permit requirements. The PDMP describes LANL's actions to minimize pesticide discharges through the use of pest management measures and monitoring/reporting of adverse incidents, including the following:

- Description of Pesticide Management Area and application sites

- Pest problem descriptions and management options

- Chemical/biological pesticides currently in use

- Response and reporting procedures for spills and adverse incidents

- Application, spill, and adverse incident reporting

\section{Projected Performance}

\section{Solid Non-Hazardous and Construction/Demolition Waste Diversion}

LANL's FY 2015 solid, non-hazardous waste and construction and demolition waste diversion performance is expected to be similar to that of FY 2014 and sustain performance levels above the $50 \%$ recycling goal. Additionally, LANL will continue to reuse clean fill generated on-site.

\section{P2 Fund Projects}

In FY 2015, LANL will provide approximately $\$ 650,000$ to generating organizations to conduct P2 projects. Presently, 12 P2 Fund Projects are undergoing final review for funding in FY 2015. These projects will be integrated with the EMS Objectives \& Targets process, as well as the Grand Challenges associated with the Long-Term Strategy for Environmental Stewardship \& Sustainability, ensuring progress is made on successful attainment of institutional goals. Using a new approach and criteria for P2 Projects in FY 2014, the P2 Program used six focus areas to identify specific areas for improvement opportunities (e.g., waste minimization/avoidance, resource conservation, process improvement, etc.). These high priority focus areas allowed organizations to identify projects and understand the alignment with institutional goals. Moving into FY 2015, the P2 program will focus on zero-waste initiatives, increased recycling and re-use, continued SF6 reduction opportunities, and waste-focused process improvements.

LANL will continue implementation of an integrated pest management plan that implements compliance with the PDMP at the worker level, including processes and forms for documenting pesticide investigation and application; adverse incident follow-up and response; spill or release reporting; list of approved pesticides; and continuous improvement practices. In addition to the PDMP, other regulatory drivers, DOE plans, and site-specific considerations impact pesticide application and management, including (but not limited to):

- Federal Insecticide, Fungicide, and Rodenticide Act (FIFRA)

- Site Sustainability Plan

- Pollution prevention and "green" products

- Physical security around nuclear and high security facilities

- Safety concerns about silica exposure and terrain-related slips/trips/falls

- Fuel mitigation and vegetation control in explosives areas

- Stormwater run-on/runoff and erosion control 
SMEs from these areas will be included in periodic reviews and discussions of pesticide management practices for urban and wildland areas as appropriate to ensure that relevant environmental and safety factors are considered.

\section{GOAL 6: SUSTAINABLE ACQUISITION}

\section{PROCUREMENTS MEET REQUIREMENTS BY INCLUDING NECESSARY PROVISIONS AND CLAUSES}

\section{Performance Status}

In FY 2014, LANL continued implementation of its Sustainable Acquisition Plan as described in previous SSP reports. This plan outlines a multi-year approach to increasing LANL's ability to meet, track, and report on sustainable acquisition goals.

\section{SSP Goal 6.1(a)}

Progress on SSP Goal 6.1(a), "to identify between 10 and 15 subcontracts that represent the largest significant suppliers of products/services that fall into EPP categories, and modify these subcontracts whenever possible to ensure that they require the supply or use of environmentally preferable products or services":

- In FY 2014, LANL reviewed and prioritized four subcontract areas to address this goal. Those focus areas and their prioritized rankings were determined to be (1) Custodial Services, (2) Furniture, (3) Cafeteria/Food Services, and (4) Electrical/Information Technology Hardware.

o The nine Custodial Services contracts were finalized and awarded during the course of FY 2014. The modifications of these contract SOWs will ensure that $100 \%$ of the custodial products used by service providers at LANL-owned or leased spaces are green products.

- To ensure $100 \%$ of all custodial products at the Lab are green, the next step will be to identify any subcontracts that allow LANL employees to buy their own cleaning materials and get those subcontracts modified also.

o The Food Services contract SOW was modified in FY 2014 to include the required EPP procurement language. This modification was performed as part of contract extension actions covering the next one to two years.

0 To address the Furniture services contract, LANL created solicitation and subcontract clauses for green/sustainable products, obtained review and approval through the LANL legal office, and published the clauses in every solicitation and subcontract pro forma. The clauses state LANL's preference to receive bids with green/sustainable products and actually be provided green/sustainable products whenever possible, as well as requiring subcontractors to support LANL green reporting requirements.

\section{SSP Goal 6.1(b)}

Progress on SSP Goal 6.1(b), "identify energy-affecting subcontracts such as service subcontracts that include electrical repair parts (e.g., repairs to HVAC systems). Modify these subcontracts whenever possible to ensure that they require the supply or use of environmentally preferable products or services":

- LANL has not made significant progress toward the accomplishment of this goal because completing 6.1(a) developed into a much larger effort than anticipated. Electrical repair parts, identified in the goal, are just one of many commodities that LANL could target and are not one of the commodities that LANL decided to prioritize. 
- In FY 2015, LANL will implementing the next phase of the Oracle business system updates/upgrades that will enable more precise data collection on the actual procurement of environmentally preferable products and enhance reporting capabilities in alignment with DOE requirements.

The above-mentioned accomplishments are due to a combination of working directly with vendors, contract administrators, and the engineering standards program to update specifications that allow LANL to meet or exceed the attribute requirements.

\section{Projected Performance}

In FY 2015, LANL will strive to increase its procurement of environmentally preferable products while simultaneously increasing its visibility of those procurements and the associated reporting capability. LANL will accomplish this through a continuing analysis of what types of products are offered under existing subcontracts for specific commodities, followed by a determination whether the appropriate types of products are offered, and a determination of whether a modification of the subcontract is possible. LANL will consider both modifications to scope and reporting requirements to accomplish this intent. Because of the complexity of this action, coupled with the possibility for increased costs and a need for internal stakeholder and subcontractor cooperation, LANL will target a relatively small population of subcontracts that represent the conduits through which a large volume of EPP are obtained. If it is determined that it would be costprohibitive or unproductive to modify a subcontract, LANL will develop a plan to modify the scope or reporting requirements upon re-solicitation for the commodities and identify the anticipated expiration date of the existing subcontract.

LANL will complete a similar analysis of existing service subcontracts that potentially supply energyaffecting repair parts and make similar efforts to modify or plan for the eventual modification of those subcontracts.

Sustainable Acquisition language continues to be incorporated in new procurements for priority products. In addition, a draft subcontract clause is under development and for incorporation into new eligible subcontracts, with a goal of inclusion in $95 \%$ of subcontracts for sustainable products and $60 \%$ for bio-based products.

\section{GOAL 7: ELECTRONIC STEWARDSHIP AND DATA CENTERS}

\section{0\% OF ALL DATA CENTERS METERED TO MEASURE MONTHLY POWER USE/UTILIZATION EFFECTIVENESS (PUE) BY FY 2015}

\section{Performance Status}

LANL has three institutional "core" data centers: the SCC, the LDCC, and the CCF. These three data centers accounted for about a quarter of the Laboratory's electrical energy use in FY 2014. The Laboratory has an Environmental and Power Monitoring System in the LDCC and the SCC. These systems enable LANL to continually trend power and temperature measurements and systematically optimize efficiencies in both data centers. The CCF PUE is calculated annually by the High Performance Computing Division. Facility upgrades to the CCF are planned by the Laboratory and will include additional power monitoring capabilities. Energy use in the SCC and the LDCC is equivalent to about $87 \%$ of the energy used in data centers on site. Energy use in the CCF is equivalent to about $8 \%$ of the energy used in data centers.

LANL has identified 86 server rooms across the site including both classified and unclassified servers. Excluding classified and large data centers from the 86 server locations, only 48 server locations exist, of which approximately one-half are less than 400 square feet in size. The unclassified data centers total almost 24,000 square feet of space. Excluding large data centers and SCIF infrastructure, the study found some 19 smaller classified data centers, totaling almost 10,000 square feet in size. 
An April 2014 review found all these data centers still in use, with only a slight change in number of servers at any location (Figure 19).

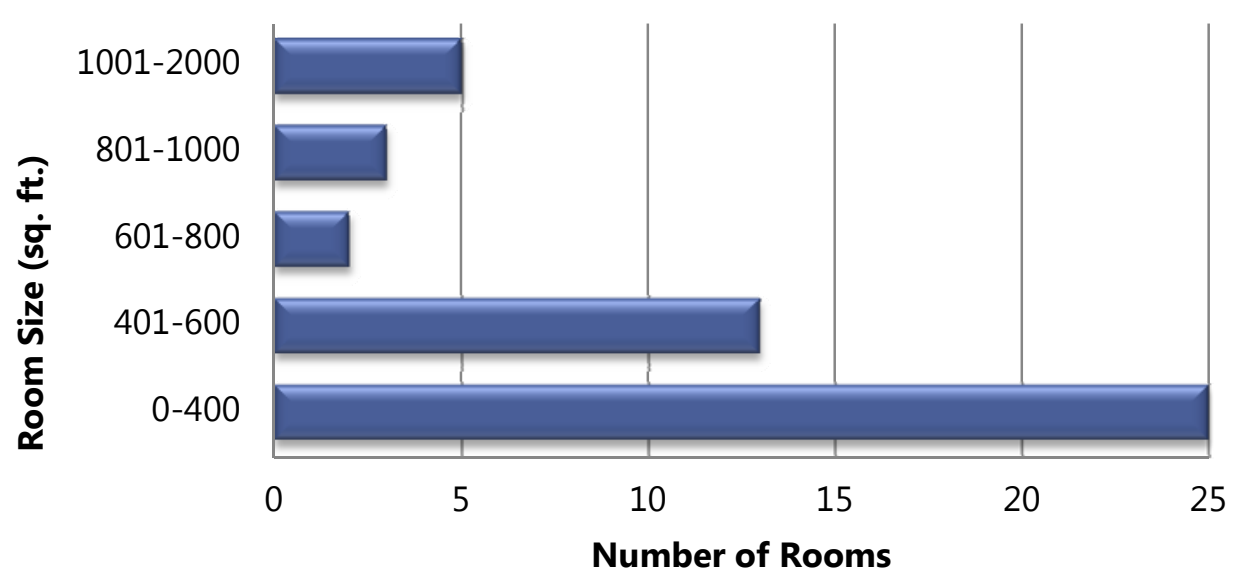

Figure 19. Unclassified Machine Room Size

To identify ways to improve data center efficiencies, LANL shares data center lessons learned, success stories, and accomplishments with other national laboratories, including Lawrence Livermore National Laboratory, Oak Ridge National Laboratory, and Lawrence Berkeley National Laboratory, and Energy Efficient High Performance Computing (HPC) Working Groups, and Supercomputing Trade Shows, as well as appropriate vendors. In addition, the Laboratory is a partner in the DOE Better Building Challenge for Data Centers. The Laboratory has committed to reducing electrical energy in the LDCC by $25 \%$ in the next five years. Recently, temperature increases in LDCC Algorithms and processes were developed and implemented to increase the temperature in the main data center in LDCC. The Laboratory will also begin to install appropriate monitoring scripts and conducting studies on clusters job loads in the SCC in preparation of increasing the temperature after Cielo (currently slated for removal in late 2016) is removed from the floor.

\section{Projected Performance}

LANL is working to implement software and hardware upgrades to update meters and enhance monitoring in the SCC and LDCC, which should be complete in 2016. Meters have been procured and software will be procured and installed in FY 2015. The LDCC will have more accurate metering after this upgrade. The new SCC infrastructure to support the new supercomputer, Trinity, will have the latest Trane and Square D software installed. In addition, installation of metering and monitoring systems for the SCC Cooling Tower project will capture data on environmental impacts of the new Trinity operations.

\section{MAXIMUM ANNUAL WEIGHTED AVERAGE PUE OF 1.4 BY FY 2015}

\section{Performance Status}

LANL closely monitors PUE in the SCC and the LDCC. LANL periodically measures and estimates PUE in the CCF. The PUE at the SCC is currently averaging 1.56, and the PUE at the LDCC is averaging at 1.57. The CCF estimated PUE is 1.47. The FY 2014 annual weighted average PUE for all three major data centers is 1.55.

A sizeable portion of the Laboratory's recent base load electrical growth is attributed to increased energy use for computers and servers across a broad spectrum of the Laboratory's programmatic work and infrastructure support. The Laboratory's trends mirror national increases in server use and electrical consumption. Excluding the SCC and LANSCE programs, the Laboratory's electrical consumption has grown from 265,606 MWh in 2008 to 396,079 MWh in 2014. The rising electrical consumption has been steadily 
increasing the cost of electricity to the Laboratory. Computer energy usage has increased to the point at which energy costs are now an important contributor to the total cost of ownership for computing infrastructure and fast approaching as the dominate life-cycle cost versus the initial capital cost of the equipment for high density computing applications.

LANL is working to consolidate existing server rooms into institutional data center space and continues to grow the institutional Infrastructure On Demand (IOD) virtualization service and provide users the opportunity to consolidate their servers. Currently, this is a voluntary effort for the programmatic server administrators. LANL plans to develop an institutional approach to close smaller building server rooms and consolidate computing resources into larger institutional data centers where feasible. This would include moving appropriate servers to IoD and either re-purposing server rooms into less energy intensive uses or closing them completely. Figure 20 illustrates the increased use of IoD services at the Laboratory.

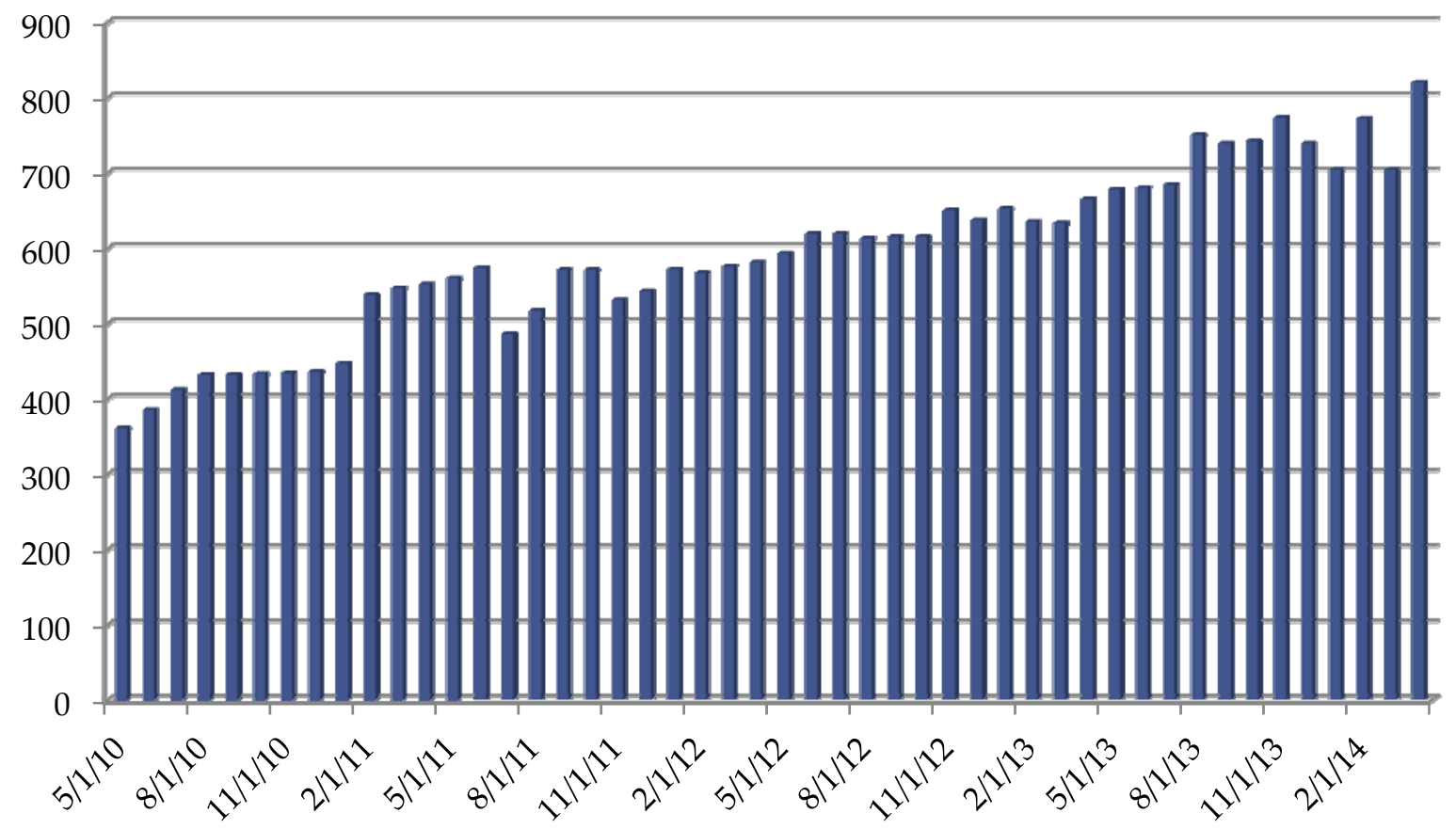

Figure 20. Number of IoD Virtual Machines 2010 to Present

Organizations included in the FY 2014 pilot project include Laboratory Legal Counsel, several Engineering groups, ISR Division, and DSA Division. The Laboratory's Legal Counsel moved to a new location in the summer of 2014, requiring the relocation of IT equipment used by both Legal Counsel and several Engineering groups (located at TA-0, Building 0760). Eight servers, four disk arrays, and associated KVM (keyboard, video, mouse) switch equipment were moved to CCF room 290 in late April 2014. The use of CCF room 290 reduced the costs of the Legal Counsel move (as a new computer room would have been built to accommodate the equipment), although the decision to move to the CCF came late in the move process. In addition, the Audits and Ethics organization completed the virtualization of two servers (moving to the Laboratory's IoD service) formerly hosted with the Legal Counsel equipment. ISR Division installed 12 racks of computing equipment in CCF rooms 270 and 290, moving out of an existing unclassified data center in the Physics Building. The existing data center required various infrastructure upgrades and would have required significant modification to meet the current fire code and install new cooling equipment. DSA Division has moved two clusters into CCF room 290. One of these clusters was moved from TA-16, out of a facility that had systemic problems with cooling infrastructure. The cluster had not been run at full capacity for months before the move. The second cluster moved from CCF room 270, allowing DSA Division to 
collocate equipment and simplifying centralized support for the systems. The net effect of these actions is the closure of three server rooms, two on Laboratory property and the third in leased space.

In addition, classified and unclassified systems have been consolidated in the new RULOB facility, vacating several older data centers at TA-55. The RULOB facility also hosts some Secure IoD (SIoD) infrastructure, in conjunction with the primary site at TA-3. In addition to consolidation of classified computing resources in the RULOB building, several other consolidation projects have taken place for Secret/Restricted Data computing resources. This includes migration to larger networks, virtualization, and physical consolidation of hardware.

To reduce costs and free up the resources needed to implement new services, the Research Library has greatly reduced the number of active servers and disk farms. Virtualization on the yellow and red networks has allowed retirement of older servers and provision of new classified services. Combined with efforts at consolidating applications on newer technology servers, Research Library staff have been able to reduce the overall number of servers in use from approximately 145 to 65 and reduce disk farms from seven to four (and soon going to two disk farms). At the same time, the square footage footprint in use in the Research Library data center has been halved.

\section{Projected Performance}

The Trinity upgrade project will modify existing infrastructure (Figure 21) to add efficient warm water cooling capability to the SCC and includes the following:

- Mechanical equipment

o Five 1200 ton open cell cooling towers

o Five cooling tower pumps: two are $150 \mathrm{HP}$ and three that $300 \mathrm{HP}$

o Four $250 \mathrm{HP}$ process pumps

o Four 3-MW Heat Exchangers

o Eight 40-mesh basket strainers: two inside and six outside

o Three air handling units for equipment cooling

- Electrical

o Two new substations

o Four new 3000A QED switch boards

o Four new power panels

After the new Trinity installation, the SCC is projected to achieve a PUE of 1.2. In addition, the SCC data center will have new LED lights. This will reduce the power required for lighting by one-third. 


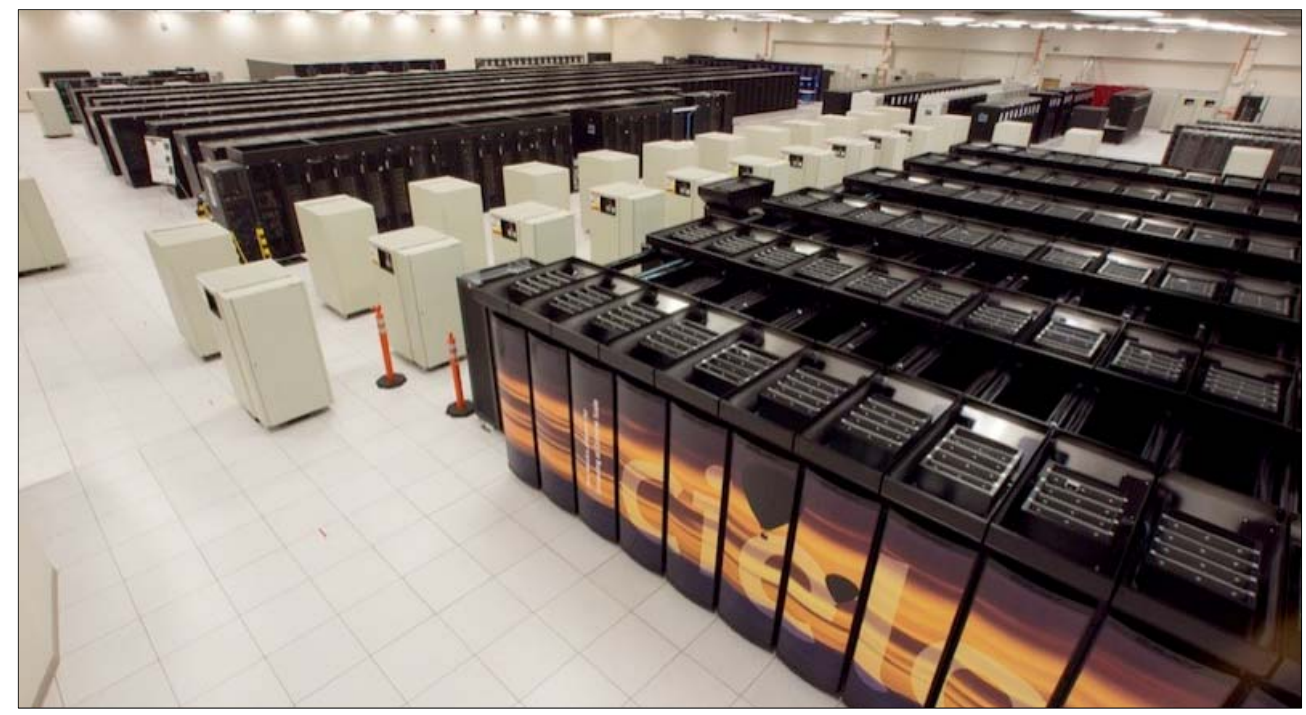

Figure 21. SCC Data Center Showing Cielo the Proposed Trinity Location

The institutional emphasis to reduce the number of distributed computer/server rooms is planned through two areas: to virtualize servers and applications and to consolidate server and high performance computing clusters into managed data centers. Managed data centers provide the most cost-effective mechanism to ensure the industry leading techniques are used to reduce energy consumption in the data center while ensuring high levels of machine availability.

\section{ELECTRONIC STEWARDSHIP - 100\% OF ELIGIBLE PCS, LAPTOPS, AND MONITORS WITH POWER MANAGEMENT ACTIVELY IMPLEMENTED AND IN USE BY FY 2012 AND THEREAFTER}

\section{Performance Status}

LANL has met the goal of $100 \%$ of eligible PCs, laptops, and monitors with power management actively implemented. To achieve that goal, LANL implemented a project in FY 2013 for power management of eligible Windows desktops and laptops using the power management capabilities of Microsoft Systems Center Configuration Manager (SCCM). SCCM leverages power settings on Windows computers to both assess power saving opportunities and to centrally manage client system power settings. These capabilities help to realize energy and cost savings.

Windows computers have built-in power settings to regulate how and when both computers and monitors are powered down to low power states, called "sleep," "standby," or "hibernate." The Windows platform has the most extensive power management capabilities of the desktop computing platforms in use at LANL, and SCCM has the ability to granularly manage those setting in an automated fashion. While the Macintosh has some limited power settings, there are no tools currently available to centrally manage those settings. The Linux platform does not include power management capabilities. Because of these platform-based limitations, the power management effort of PCs at LANL is limited to Windows. Fortunately, Windows computers make up close to $80 \%$ of the desktops in use at LANL.

LANL does not attempt to manage power settings on Windows server systems for obvious reasons, as most servers are designed to have 24/7 availability. Some desktops may also be considered ineligible for power management if they are either incapable of being put into a low power state due to hardware limitations (including virtual computers), or have requirements to be constantly powered on for running experiments, collecting data, or other similar operations. To summarize, computers "eligible" for power management at LANL include all Windows desktops and laptops on the unclassified network except: 
- Computers with incapable hardware

- Virtual computers

- Computers that are voluntarily excluded due to programmatic needs that preclude power management

\section{Projected Performance}

LANL has implemented this goal. Further, due to situations where many Windows systems are failing to sleep at the designated time, the projected cost savings using SCCM may not be as high as initially projected. The DCS-CSD SCCM team is currently evaluating third-party products that actually power off and power on Windows systems rather than putting them into sleep mode.

\section{Actual Cost Savings}

- Average cost per computer per month

o Production: October 2013 - September 2014

- Average number of systems reporting: 8,685

- Average power cost/system/month: $\$ 2.35$

- Savings per system: $\$ 0.35$

- $\quad$ Savings for 8,685 workstation clients for FY14: $\$ 3040 /$ month, $\$ 36,477 /$ year

\section{GOAL 8: RENEWABLE ENERGY}

\section{$20 \%$ OF ANNUAL ELECTRICITY CONSUMPTION FROM RENEWABLE} SOURCES BY FY 2013 AND THEREAFTER (FY 2013 TARGET: 7.5\%)

\section{Performance Status}

LANL exceeded the 7.5\% renewable energy goal in FY 2014. The Laboratory used approximately 386,000 MWh of electricity in FY 2014 including on-site renewable generation. Including the allowable double credit for federal site production and the Abiquiu Dam Low Flow Turbine (LFT), LANL reported a total of 20,016 MWh of renewable energy used on-site. LANL purchased 27,000 Green-e Certified RECs from Oklahoma wind farms. In addition to on-site renewable energy used, this amounts to $12 \%$ of the annual electricity consumption.

In addition, LANL supported NNSA to renegotiate the Los Alamos County Electric Coordination Agreement.

\section{Projected Performance}

LANL plans to meet the FY 2020 renewable energy goal by either purchasing RECs to replace fossil-fueldependent energy or focusing on a power purchase agreement (PPA) for lower or no carbon-producing energy in order to change its generation mix to reduce the carbon footprint of electricity supplies. One option under consideration is contracting for renewable power as the source of supply once the generation owned by Los Alamos County cannot meet demand. In addition, LANL is requesting an update to the 2008 Renewable Energy Feasibility Study through the Federal Energy Management Program in order to propose further onsite renewable investments. The Abiquiu LFT is estimated to conservatively produce 7,000 MWh per year, which is $18,400 \mathrm{MWh}$ with double credit for on-site production.

\section{GOAL 9: CLIMATE CHANGE ADAPTATION}

LANL does not have a designated point of contact for climate change planning, but many programs and plans are in place that address the climate change projections for the Los Alamos area. 


\section{Climate Change Projections for the Los Alamos Area}

1. Analysis of the Southwest US climate using 17 global climate models indicates that a climate regime outside the range of historic variability will develop during this century. Average climate conditions will be more arid than even the hottest, driest years in the historical record

2. Warming temperatures are already being observed. Over the period 1971 through 2011 , average temperatures in the Upper Rio Grande Basin rose at a rate of just under 0.7 degrees Fahrenheit $\left({ }^{\circ} \mathrm{F}\right)$ per decade, approximately double the global rate of temperature rise. The decade 2001-2010 was the warmest in the 110-year instrumental record, with temperatures almost $2^{\circ} \mathrm{F}$ higher than historic averages. Regional annual average temperatures are projected to rise $2.5^{\circ} \mathrm{F}$ to $5.5^{\circ} \mathrm{F}$ by $2041-2070$ and $5.5^{\circ} \mathrm{F}$ to $9.5^{\circ} \mathrm{F}$ by $2070-2099$ with continued growth in global emissions. If global emissions are substantially reduced, projected temperature increases are $2.5^{\circ} \mathrm{F}$ to $4.5^{\circ} \mathrm{F}(2041-2070)$, and $3.5^{\circ} \mathrm{F}$ to $5.5^{\circ} \mathrm{F}(2070-2099)$.

3. No significant declines in average annual precipitation over 30 -year time spans have yet been observed. In the northern part of the Southwest, projected winter and spring precipitation changes are less than natural variations. Projected summer and fall changes are less than natural variations throughout the region. Late winter and spring mountain snowpacks are expected to decrease, mostly because of the effects of warmer temperatures. There is high confidence that winter precipitation will continue to shift from non-erosive snow to erosive rainfall due to increasing winter temperatures.

4. The Southwest is prone to drought. Paleoclimate records for the Southwest show severe megadroughts at least 50 years long. Future droughts are expected to occur at least at the same frequency, but to be accompanied by substantially hotter temperatures. More heat waves and fewer cold waves occurred in the Southwest during 2001-2010 compared to average occurrences in the 20th century.

\section{OBJECTIVE 1: DOE CLIMATE CHANGE ADAPTATION SCREENING ASSESSMENT}

LANL completed the Climate Change Adaptation screening assessment.

\section{OBJECTIVE 2: DETERMINING RISK}

The following are climate-change-related impacts and associated risks that have the greatest potential to affect site mission, operations, and personnel at LANL.

1. Increased Risk of Wildfire: Projected climate changes suggest that forests in the western United States will be increasingly affected by large and intense fires that occur more frequently. Wildfire risk increases with drought as vegetation dies and fuel moisture decreases. LANL has been impacted by two major wildfires in the past 15 years. The latest SWEIS (2008) calculated the risk of a wildfire reaching the LANL boundary at $10 \%$ annually. Wildfire reduces vegetation cover and increases rates of soil erosion, flooding, sediment transport, and associated pollutant transport. LANL maintains an active Wildfire Management Program to mitigate wildfire risk and respond to active wildfire threats. Risks are evaluated periodically and mitigation work packages are submitted to the annual budgeting process.

2. Increased Soil Erosion Rates: Soil erosion rates are projected to increase as vegetation cover decreases and more precipitation falls as rain, instead of snow. In addition, as we lose needleleaf evergreen forests to catastrophic wildfire, drought, or insect infestations, we will also lose the deep protective litter and duff layers associated with those forest types. Catastrophic wildfire in particular results in greatly increased erosion rates in the affected areas. LANL is currently developing a Stormwater Management Program to coordinate management across multiple programs of stormwater, flooding impacts, soil erosion, and sediment discharge. Coordination with the Forest Management Program would address widespread soil erosion issues that result from climate change impacts. 
3. Streamflow Reduction: Models for the Upper Rio Grande basin predict that by 2100 total annual streamflows will be about one-third lower than present flows because of changes to the timing and magnitude of water inputs and temperature-driven increases in evaporation and water use by plants. Summertime flows are expected to decrease sharply, with wintertime flows having less of a decrease, or potentially even an increase. Peak flows would shift from June to April and May. Drought and subsequent low water levels could affect hydroelectric power generation from the Abiquiu Hydroelectric Plant.

4. Periodic Flooding: Flooding in canyons has increased at LANL as a result of drought, wildfire, and extreme rainfall events. A 1,000-year flood event in September 2013 resulted in greater than \$7.4 M in damages to infrastructure, including monitoring wells, gage stations, and road crossings, in addition to increased channel and bank erosion and sediment and pollutant transport.

5. Increased Tree Mortality: Consensus among climate-vegetation model simulations for western North America is that about half of the needleleaf evergreen tree coverage will disappear by the end of this century, accompanied by a doubling of the area covered by shrubs and grasses (Jiang et al. 2013). LANL recently developed a Forest Management Plan with Forest Health thinning prescriptions designed to increase forest resistance to climate change impacts. We are coordinating activities with the Wildland Fire Management Program to implement treatments as funding is available.

6. Expansion of Non-Native Plants: Another concern related to climate change is the potential expansion of non-native invasive plant species. Non-native species, similar to native species, will respond to climate change according to their individual environmental tolerances; some species are projected to increase and some to decrease. Substantial changes in plant community composition may radically alter wildlife habitat and ecosystem function. Management of invasive species is a component of the LANL Forest Management Program. Occurrences of invasive species will be tracked, and we will work with other Lab organizations to control the introduction and spread of these species.

7. Increased cost of electrical supply: LANL receives a portion of its electricity from the San Juan Generating Station (SJGS) in northwest New Mexico. The SJGS has four coal-burning generators that will require emissions upgrades. A small portion of LANL's electricity comes from the Abiquiu and El Vado Hydroelectric Plants, which could be impacted by low water levels in their respective reservoirs. Future power sources to mitigate climate impacts will likely increase the cost of electricity for the site as we seek to switch to renewable and non-carbon electrical generation resources.

\section{OBJECTIVE 3: CURRENT ACTIVITIES}

Ongoing plans designed to address climate impacts to missions, operations, and people, as well as policies and programs that include consideration of climate risks:

1. LTSESS is a program designed to evaluate risks and determine strategies for long-term environmental issues, including climate change. LTSESS submits an annual work plan to the Los Alamos Field Office.

2. The Forest Management Plan, completed in 2014, describes prescriptions to reduce wildfire fuels and restore or preserve forest health under changing climatic conditions.

3. The Wildland Fire Management and Emergency Response programs at LANL are equipped for realtime wildfire behavior modeling, strategic and emergency planning, fuels mitigation, and fire suppression activities. LANL houses an interagency Emergency Operations Center and an interagency fire base with a helicopter and crew on site during the fire season.

4. This SSP was developed in response to DOE Order 436.1, Departmental Sustainability. The SSP sets goals for energy conservation, transportation, and water conservation including the Sanitary Effluent Reclamation Facility-Expansion (SERF-E). Water from the Lab's sanitary wastewater treatment plant 
is pumped to the SERF, cleaned, and reused in cooling towers. Water can be recycled up to eight times before releasing it back to the environment.

5. The Laboratory maintains a robust environmental surveillance program monitoring long-term trends in air quality, surface water, groundwater, soils, foodstuffs, and biota. Monitoring program results are published annually in the Annual Site Environmental Report. The latest 2013 report is available at: http://www.lanl.gov/community-environment/environmentalstewardship/environmental-report.php

6. After the Las Conchas Fire in 2011, a major programmatic effort was mounted to repackage and ship 3,706 cubic meters of transuranic waste to the Waste Isolation Pilot Plant. This program was a direct response to the threat of wildfire on the Pajarito Plateau.

7. After the 2013 flood event, the program for environmental restoration managing contaminants in canyons was redesigned. During the flood, the program suffered significant losses of monitoring equipment, roads, and other infrastructure.

\section{OBJECTIVE 4: FUTURE ACTIVITIES}

Future plans designed to address climate impacts to missions, operations, and people, as well as policies and programs, will be modified to include consideration of climate risks:

1. The Laboratory is developing a Stormwater Management Plan to address institutional stormwater quality and flooding issues. The plan will document a long-term strategy for improving water quality and stormwater hydrologic conditions.

2. The Laboratory has initiated a new comprehensive site planning process, partly in recognition that climatic events have had significant negative impacts on operations and infrastructure since the last comprehensive site plan in 2000 . The intent is to provide a vision for Laboratory operations and infrastructure for a 25- to 30-year planning horizon. Such planning will now include processes, procedures, and policies to account for climate change impacts.

3. Power supply review to change LANL's power generation mix to reduce GHG emissions.

\section{OBJECTIVE 5: REAL PROPERTY AND SUPPLY CHAIN RESILIENCE}

Existing or ongoing efforts to include considerations of climate adaptation and resilience into procurement, acquisition, real property, or leasing decisions:

1. The Lab is in the process of developing and implementing the Long-Range Infrastructure Development Plan. Climate adaptation, resilience, and site sustainability are important factors in the procurement of real property.

\section{OBJECTIVE 6: REGIONAL AND LOCAL COORDINATION}

Regional and local partnerships with other federal agencies, municipalities, and local organizations that improve our understanding of climate change science, share best practices and data, and establish regional coordination in planning and policy:

1. The LANL Institute of Geophysics, Planetary Physics, and Signatures has sponsored climate research at LANL since 1984. General focus areas include studies that extend our understanding of the causes of temporal variations of ocean and atmospheric basin scale oscillations; rapid climate change on both global and regional scales; and the physics and chemistry governing storms, hydrology, geomorphic processes, and land use with a region experiencing climate change. Current funded projects include detection of climate signals from millennial length ice cores; real-time methane observation: attributing sources from Arctic and gas fields; and canopy carbon dynamics in a hotter, drier climate.

2. Scientists and researchers in LANL's Earth and Environmental Sciences Division conduct national, multi-lab initiatives to use the most advanced observational and experimental capabilities available 
to address critical problems facing our world. The Computational Earth Science Group uses high performance computing to examine microscale, mesoscale, and global-scale atmospheric phenomena, and model wildland and urban fire phenomena. The Earth Systems Observation Group has major projects in carbon capture utilization and storage and tree mortality related to drought and temperature. Teams from this group operate stationary and mobile climate research facilities worldwide, study impacts of fire emissions and aerosol-cloud-precipitation interactions on global climate, and contribute to the DOE-Biological and Environmental Research Next Generation Ecosystem Experiment to examine climate change impacts and feedbacks in the Arctic.

3. The DOE Office of Science funds the Climate, Ocean, and Sea Ice Modeling project in the Computer, Computational, and Statistical Sciences Division at LANL. For more than 20 years, the project has been developing high performance component models of the ocean, sea ice, and land ice. The team members apply models to sea level rise, rapid changes in the Arctic, global circulation of the ocean, and biogeochemical ecosystem interactions such as methane release.

4. Following the Cerro Grande Fire in 2000, a state of the art Emergency Operations Center (EOC) was constructed capable of handling multi-agency emergency response and coordination activities. The EOC is largely self-sufficient, running on natural gas with diesel fuel backup systems.

5. An interagency fire base was established on Lab property to support wildfire suppression efforts in the local area.

6. The East Jemez Resources Council is an interagency group of natural resources management professionals that meets twice a year to discuss current and future management issues, including climate change impacts. Meetings are regularly attended by individuals from DOE, LANL, the USFS, the US Park Service, The Valles Caldera National Preserve, the Nature Conservancy, NMED, the New Mexico State Forestry Department, local Pueblos, and Los Alamos County.

7. LANS is a member of the Energy Federal Contractors Group (EFCOG), which provides a forum for sharing information, issues, and best practices on climate adaptation across the DOE Complex through EFCOG subgroups on environment and sustainability. EFCOG has a sustainability initiative to support sites in meeting the Executive Order on Federal Leadership in Environmental, Energy, and Economic performance.

\section{OBJECTIVE 7: REMOVING AND REFORMING BARRIERS}

Existing barriers and how they're being addressed:

- The Lab is in the process of developing and implementing the Long-Range Infrastructure Development Plan. One objective of the plan will be to identify and reform policies or programs that result in unintentional barriers to effective management, including vulnerability to climate change. 


\section{REFERENCES}

DOE (US Department of Energy), 1995. Dual Axis Radiographic Hydrodynamic Test Facility Final Environmental Impact Statement, DOE/EIS-0228, Albuquerque Operations Office, Los Alamos Area Office, Albuquerque, New Mexico, August 1995.

DOE (US Department of Energy), 1998. Environmental Assessment for the Proposed Strategic Computing Complex, Los Alamos National Laboratory, Los Alamos, New Mexico, DOE/EA-1250, Los Alamos Area Office, Los Alamos, New Mexico, December 1998.

DOE (US Department of Energy), 1999. Site-Wide Environmental Impact Statement for Continued Operation of the Los Alamos National Laboratory, Los Alamos, New Mexico, DOE/EIS-0238, Albuquerque Operations Office, Albuquerque, New Mexico, January 1999.

DOE (US Department of Energy)/National Nuclear Security Administration (NNSA), 2008. Site-Wide Environmental Impact Statement for Continued Operation of Los Alamos National Laboratory, Los Alamos, New Mexico, DOE/EIS-0380, Los Alamos Site Office, Los Alamos, New Mexico, May 2008.

DOE (US Department of Energy), 1999. Final Environmental Impact Statement for the Conveyance and Transfer of Certain Land Tracts Administered by the US Department of Energy and Located at Los Alamos National Laboratory, Los Alamos and Santa Fe Counties, New Mexico, DOE/EIS-0293, Los Alamos Area Office, Los Alamos, New Mexico, October 1999.

DOE (US Department of Energy) 2011. Order 436.1, Departmental Sustainability, May 2, 2011. Document can be found through search at http://www.directives.doe.gov.

DOE (US Department of Energy) 2010. Strategic Sustainability Performance Plan, August 3, 2010. Document can be found through search at http://www.energy.gov/media/DOE_Sustainability_Plan_2010.PDF.

Executive Order 13514, 2009. Federal Leadership in Environmental, Energy, and Economic Performance, October 8, 2009. Document can found through search at http://edocket.access.gpo.gov/2009/pdf/E924518.pdf.

LANL (Los Alamos National Laboratory), 1998. “Water Supply at Los Alamos during 1997," Los Alamos National Laboratory report LA-I 3548-PR, Los Alamos, NM.

LANL (Los Alamos National Laboratory), 2003. “Water Supply at Los Alamos 1998-2001,” Los Alamos National Laboratory report LA-13985-PR, Los Alamos, NM.

LANL (Los Alamos National Laboratory), 2008. Renewable Energy Feasibility Study, LA-UR-09-07 230, Los Alamos National Laboratory, Los Alamos, New Mexico, November 2008.

LANL (Los Alamos National Laboratory), 2014. Long-Term Strategy for Environmental Stewardship and Sustainability, LA-UR-14-28025, Los Alamos National Laboratory, Los Alamos, New Mexico.

Public Law 109-58, 2005. Energy Policy Act of 2005, August 8, 2005. Document can be found through search at http://thomas.loc.gov.

United States Congress, 2007. Energy Independence and Security Act of 2007, 2007, Washington, D.C. Document can be found through search at http://www2.epa.gov/laws-regulations/summary-energyindependence-and-security-act. 


\section{ABBREVIATIONS AND ACRONYMS}

${ }^{\circ} \mathrm{F}$

AFV

ASHRAE

BAS

BTU

C\&D

CCF

CD

CEDR

CEQ

CINT

CMRR

CMSA

DARHT

DM

DOE

EAP

ECM

EFCOG

EI

EISA

EMS

EOC

EPA

EPP

ESPC

ESS

FIMS

FIRP

FOD

FTE

FY

GHG

GP

GPP

GSF

GVWR

HPC

HPSB

HVAC

ILA

IOD
Degrees Fahrenheit

Alternative Fuel Vehicle

American Society of Heating, Refrigeration, and Air-Conditioning Engineers

Building Automation System

British Thermal Units

Construction \& Demolition

Central Computing Facility

Critical Decision

Consolidated Energy Data Report

Council on Environmental Quality

Center for Integrated Nanotechnology

Chemistry and Metallurgy Research Replacement Facility

Consolidated Metropolitan Statistical Area

Dual Axis Radiographic Hydrodynamic Test facility

Deferred Maintenance

Department of Energy

Environmental Action Plan

Energy Conservation Measure

Energy Federal Contractors Group

Enterprise Infrastructure

Energy Independence and Security Act of 2007

Environmental Management System

Emergency Operations Center

Environmental Protection Agency

Environmentally Preferable Purchasing

Energy Savings Performance Contract

Equipment Surveillance System

Facilities Information Management System

Facility and Infrastructure Recapitalization Project

Facility Operations Director

Full-Time Equivalent

Fiscal Year

Greenhouse Gas

Guiding Principles

General Plants Project

Gross Square Feet

Gross Vehicle Weight Rating

High Performance Computing

High Performance Sustainable Buildings

Heating, Ventilation, and Air Conditioning

Industrial, Landscape, and Agricultural

Infrastructure On Demand 
ISO International Organization for Standardization

IT Information Technology

kW Kilowatt

$\mathrm{kWh} \quad$ Kilowatt-Hour

LANL Los Alamos National Laboratory

LANS Los Alamos National Security, LLC

LANSCE Los Alamos Neutron Science Center

LDCC Laboratory Data Communications Center

LDV Light Duty Vehicle

LEED Leadership in Energy and Environmental Design

LFT Low Flow Turbine

LRDP Long-Range Development Plan

LTSESS Long-Term Strategy for Environmental Stewardship \& Sustainability

M4

MaRIE

Making, Measuring, and Modeling Materials Laboratory/Office

MBTU

Matter-Radiation Interactions in Extremes

MLLW

Million British Thermal Units

MRRL

MSA

Mixed Low-Level Waste

NAABB

Methanol Recirculation and Recovery Loop

NECPA

Metropolitan Statistical Area

$\mathrm{NF}$

National Alliance for Advanced Biofuels and Bioproducts

National Energy Conservation Policy Act

NISC

Nuclear Facility

NMED New Mexico Environment Department

NMRR New Requirements and Major Maintenance

NMSSUP Nuclear Materials Safeguards and Security Upgrade Project

NNSA National Nuclear Security Administration

NPDES National Pollutant Discharge Elimination System

NPS National Park Service

NRDA Natural Resources Damage Assessment

NRMM New Requirements of Major Maintenance

NSSB National Security Sciences Building

OMB Office of Management and Budget

P2 Pollution Prevention

PADOPS Principal Associate Director for Operations and Business

PDMP Pesticide Discharge Management Plan

PF Plutonium Facility

PNNL Pacific Northwest National Laboratory

PUE Power Use/Utilization Effectiveness

RAMP Roof Asset Management Program

RECs Renewable Energy Certificates

RLUOB Radiological Laboratory, Utilities, and Office Building

RLWTF Radioactive Liquid Waste Treatment Facility

ROI Return on Investment 
SAP Sustainable Acquisition Plan

SCC Strategic Computing Complex (also known as Metropolis Center)

SCCM Microsoft Systems Management Server 2007

SERF Sanitary Effluent Reclamation Facility

SERF-E Sanitary Effluent Reclamation Facility-Expansion

SIoD Secure Infrastructure on Demand

SJGS San Juan Generating Station

SME Subject Matter Expert

SOC LANL Protective Force

SSP Site Sustainability Plan

SSPP Strategic Sustainability Performance Plan

SWEIS Site-Wide Environmental Impact Statement

TA Technical Area

TRP Technical Area 55 Reinvestment Project

TRU Transuranic

TTF Tactical Training Facility

TYSP Ten-Year Site Plan

UI Utilities and Institutional Facilities

USFS US Forest Service

USGBC United States Green Building Council

WMC Waste Management Coordinator 


\section{ATTACHMENTS}

1) LANL Consolidated Energy Data Report Summary 
CEDR Performance Summary

\begin{tabular}{|c|c|c|c|c|c|}
\hline $\begin{array}{c}\text { SSPP } \\
\text { Goal \# }\end{array}$ & DOE Goal & Baseline & FY 2013 & FY 2014 & $\begin{array}{l}\text { Performance } \\
\text { Status } \\
\text { (FY 2014) }\end{array}$ \\
\hline 1.1 & $\begin{array}{l}28 \% \text { Scope } 1 \& 2 \text { GHG reduction by FY } 2020 \text { from a FY } \\
2008 \text { baseline }\end{array}$ & $323,046.1$ & $224,554.9$ & $261,453.3$ & $-19.1 \%$ \\
\hline 1.2 & $\begin{array}{l}\text { 13\% Scope } 3 \text { GHG reduction by FY } 2020 \text { from a FY } 2008 \\
\text { baseline }\end{array}$ & $74,814.3$ & $55,165.8$ & $55,254.5$ & $-26.1 \%$ \\
\hline \multirow[t]{3}{*}{2.1} & $\begin{array}{l}30 \% \text { energy intensity reduction by FY } 2015 \text { from a FY } \\
2003 \text { baseline } \\
\text { (Note: Estimates without REC credit) }\end{array}$ & 227,880 & 201,028 & 192,573 & $-15.5 \%$ \\
\hline & Goal Energy (10^6 Btu) & $1,758,604$ & $1,443,459$ & $1,378,204$ & \\
\hline & Goal Square Footage $(x 1,000)$ & 7,717 & 7,180 & 7,157 & \\
\hline $2.3 a$ & $\begin{array}{l}\text { Individual buildings or processes metering for } 90 \% \text { of } \\
\text { electricity (by October } 1,2012 \text { ) }\end{array}$ & & & $87.8 \%$ & $87.8 \%$ \\
\hline $2.3 b$ & $\begin{array}{l}\text { Individual buildings or processes metering for } 90 \% \text { of } \\
\text { natural gas (by October } 1,2015 \text { ) }\end{array}$ & & & $62.8 \%$ & $62.8 \%$ \\
\hline $2.3 c$ & $\begin{array}{l}\text { Individual buildings or processes metering for } 90 \% \text { of } \\
\text { steam (by October } 1,2015 \text { ) }\end{array}$ & & & $18.0 \%$ & $18.0 \%$ \\
\hline $2.3 d$ & $\begin{array}{l}\text { Individual buildings or processes metering for } 90 \% \text { of } \\
\text { chilled water (by October } 1,2015 \text { ) }\end{array}$ & & & $0.0 \%$ & $0.0 \%$ \\
\hline 3.1 & $\begin{array}{l}10 \% \text { annual increase in fleet alternative fuel consumption } \\
\text { by FY } 2015 \text { relative to a FY } 2005 \text { baseline }\end{array}$ & 8,887 & 42,657 & 42,657 & $380.0 \%$ \\
\hline 3.2 & $\begin{array}{l}\text { 2\% annual reduction in fleet petroleum consumption by } \\
\text { FY } 2020 \text { relative to a FY } 2005 \text { baseline } \\
\text { (Note: Estimates without biodiesel credit) }\end{array}$ & 661,801 & 506,005 & 506,005 & $-23.5 \%$ \\
\hline \multirow{3}{*}{4.1} & $\begin{array}{l}26 \% \text { water intensity reduction by FY } 2020 \text { from a FY } 2007 \\
\text { baseline }\end{array}$ & 37.2 & 45.3 & 35.9 & $-3.5 \%$ \\
\hline & Potable Water Consumption $\left(10^{\wedge} 6 \mathrm{Gal}\right)$ & 336 & 387 & 306 & \\
\hline & Total Gross Square Footage $(x 1,000)$ & 9,036 & 8,550 & 8,524 & \\
\hline 4.2 & $\begin{array}{l}20 \% \text { water consumption reduction of industrial, } \\
\text { landscaping, and agricultural (ILA) water by FY } 2020 \text { from } \\
\text { a FY } 2010 \text { baseline }\end{array}$ & 0 & 0 & 0 & $\mathrm{~N} / \mathrm{A}$ \\
\hline 5.1 & $\begin{array}{l}\text { Divert at least 50\% of non-hazardous solid waste, } \\
\text { excluding construction and demolition debris, by FY } 2015\end{array}$ & & $56.9 \%$ & $53.8 \%$ & $53.8 \%$ \\
\hline 5.2 & $\begin{array}{l}\text { Divert at least } 50 \% \text { of construction and demolition } \\
\text { materials and debris by FY } 2015\end{array}$ & & $99.0 \%$ & $93.0 \%$ & $93.0 \%$ \\
\hline 6.1 & $\begin{array}{l}\text { Procurements meet requirements by including necessary } \\
\text { provisions and clauses }\end{array}$ & & $100.0 \%$ & $100.0 \%$ & $100.0 \%$ \\
\hline 7.3 & $\begin{array}{l}\text { 100\% of eligible PCs, laptops, and monitors with power } \\
\text { management actively implemented and in use by FY } 2012\end{array}$ & & $100.0 \%$ & $100.0 \%$ & $100.0 \%$ \\
\hline \multirow[t]{3}{*}{8} & $\begin{array}{l}20 \% \text { of annual electricity consumption from renewable } \\
\text { sources by FY } 2020 \text { and thereafter (5\% FY } 2010-2012 \text {, } \\
7.5 \% \text { 2013) }\end{array}$ & & $8.5 \%$ & $11.9 \%$ & $11.9 \%$ \\
\hline & Renewable Electricity Usage (MWh) & & 31,708 & 47,017 & \\
\hline & Total Electricity Usage (MWh) & & 373,413 & 395,988 & \\
\hline
\end{tabular}

